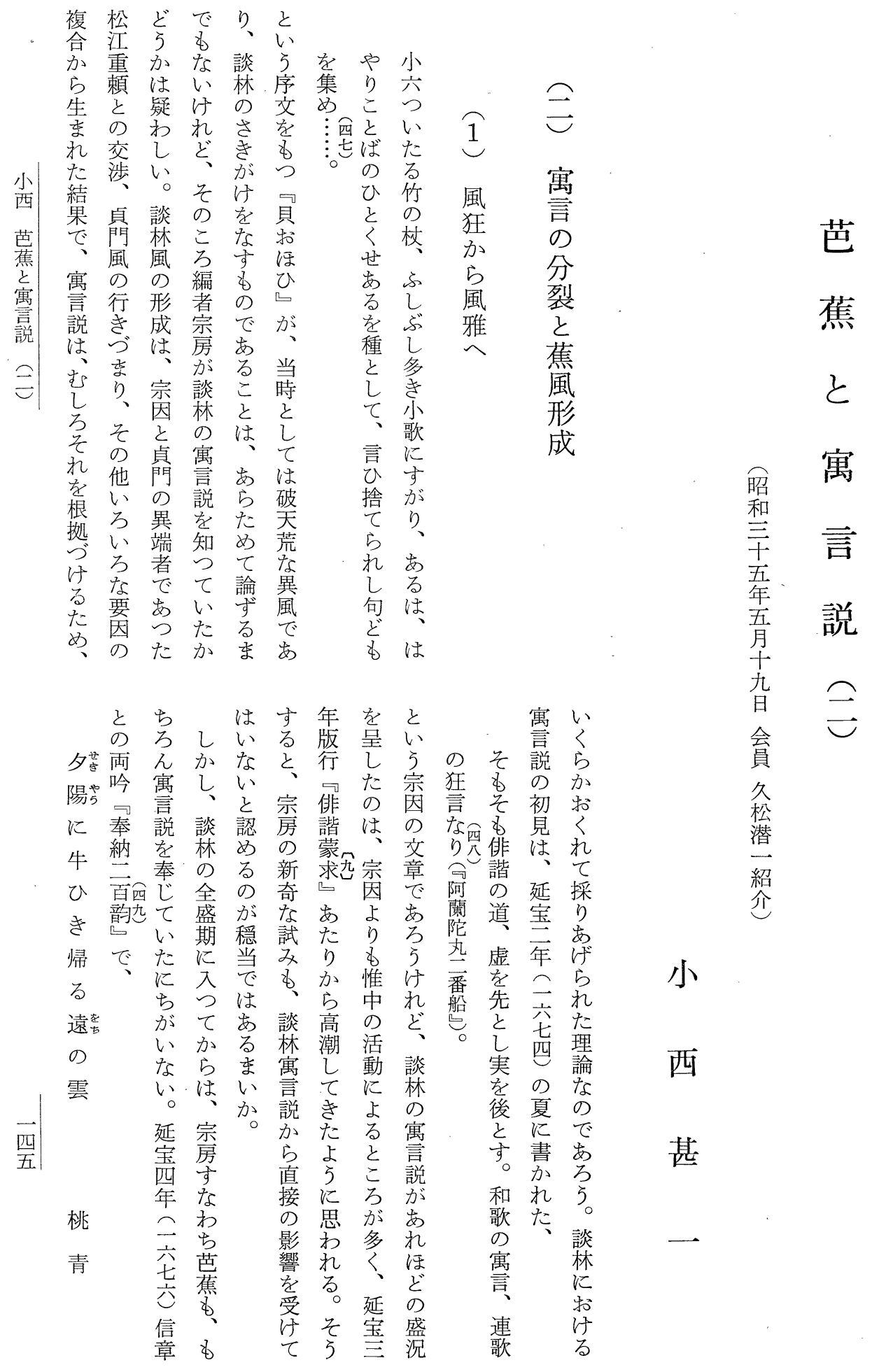


とル斎言道立両でと

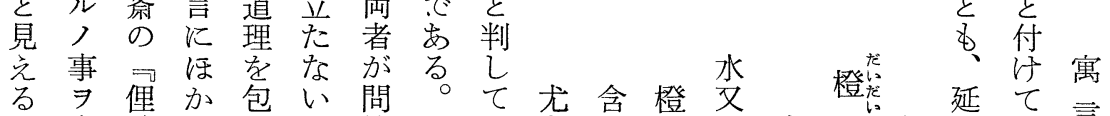

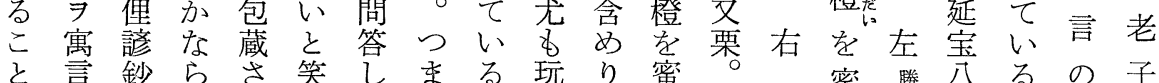

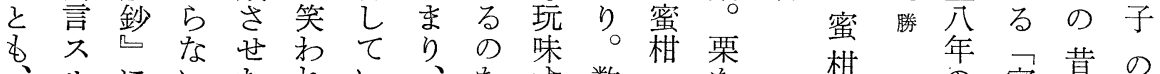

さノルに

き類夜と䒚

引実禹すすお ほ

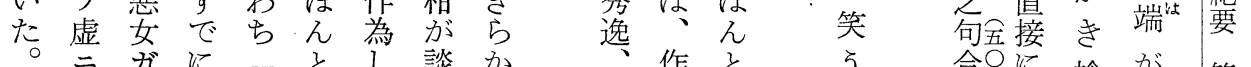

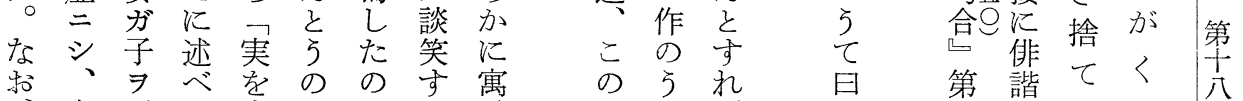

拉虚平 だを含大 がる

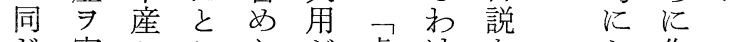

じ実主こりが虚计をを敃作

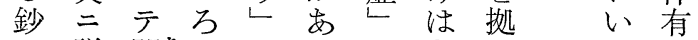

に、説っ闇でに る でな り

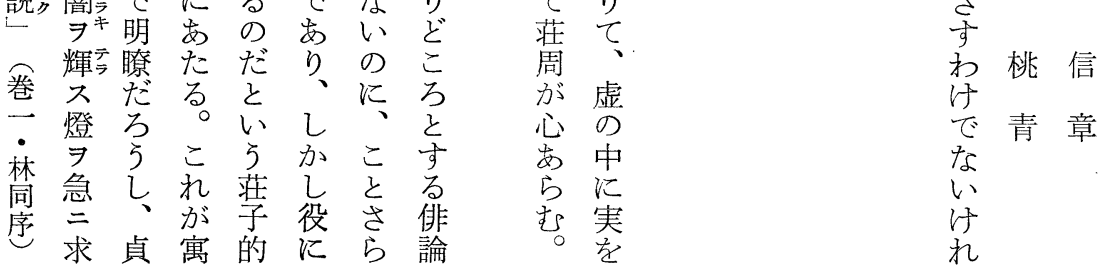

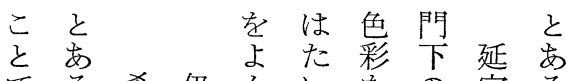

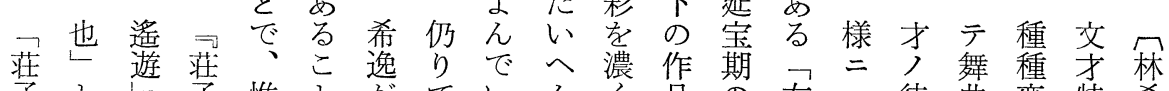

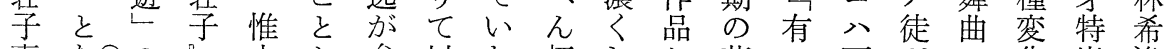
妻主の凹中台弁以た趣し 色 死济篇 恵分 林 の 俳定に 是 こ に

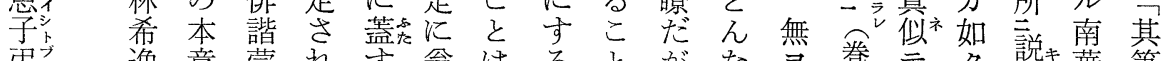
韦引 逸 意蒙れ 鬲 翁

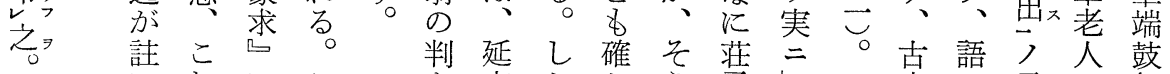

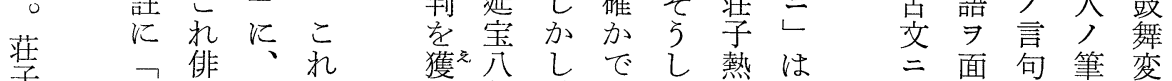

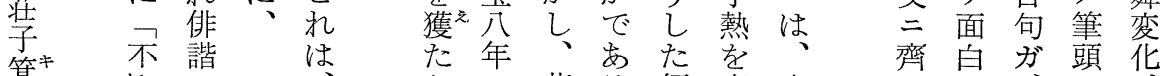

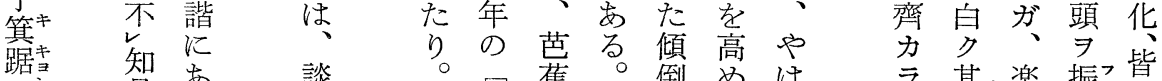

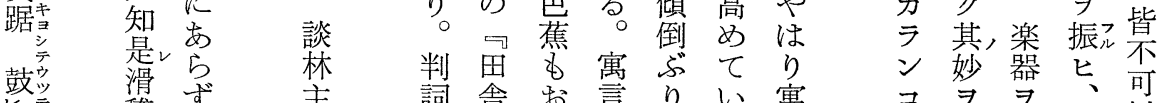

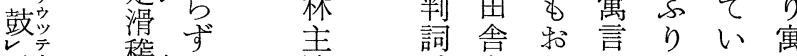

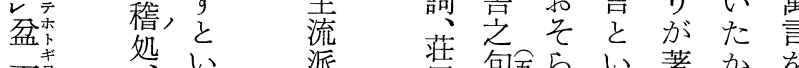

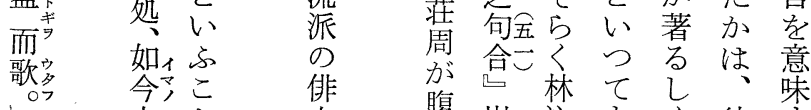

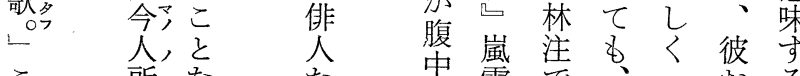

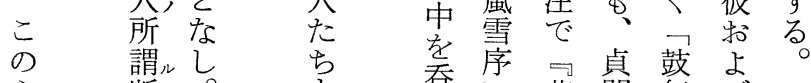

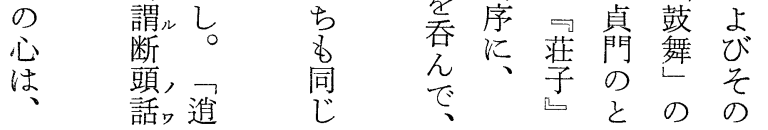
と の

ב 卜 尽兴用有 尋 四

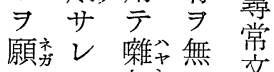
類レ起总二字 文、袂 無 往 交後章突求 下 人 


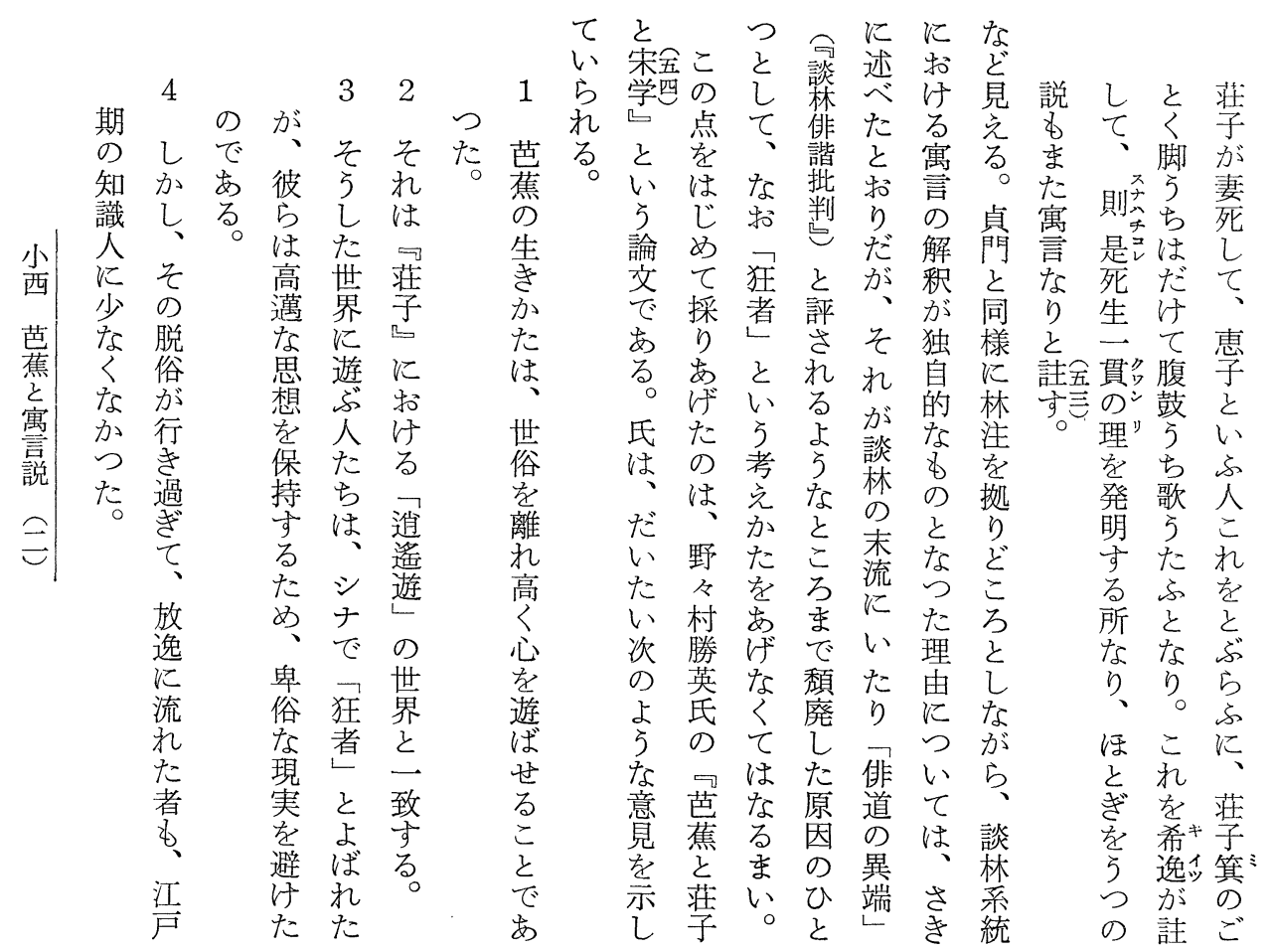

語れ風の禅者とと村たととでいとの

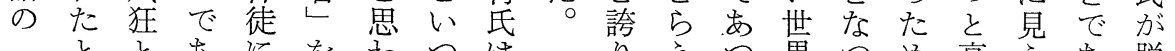

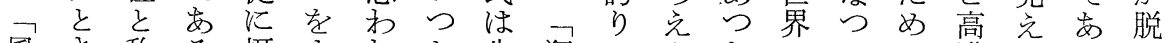

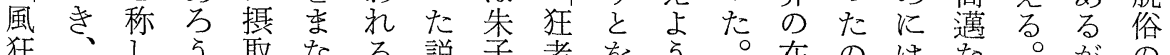

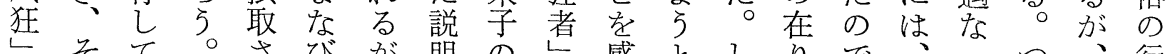

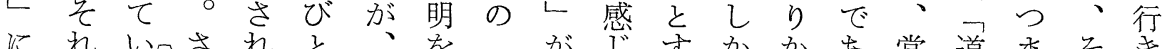

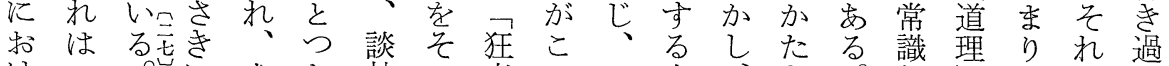

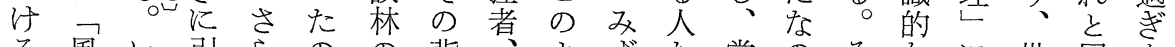

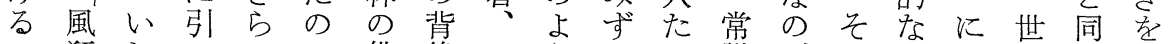
風狂わいにで俳後志 5 から識だら表徹俗じ指 風しゆた通は人に極にらはをとし現し 的精摘

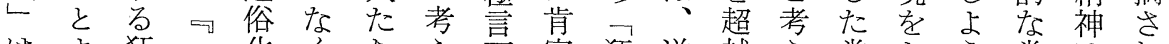

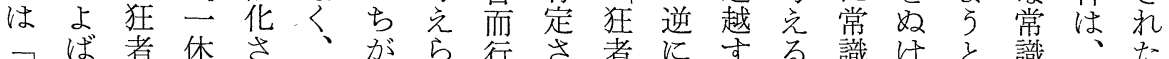

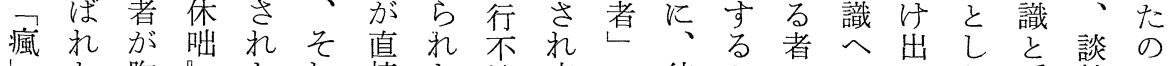
た胸にたれ接た掩支で彼とののるた妥林は、

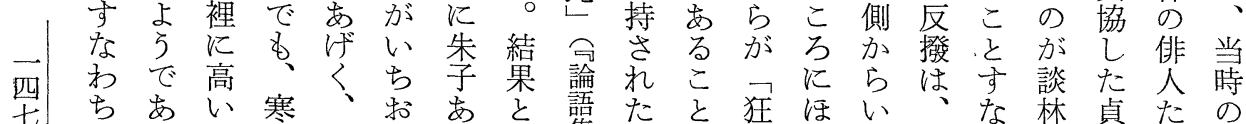

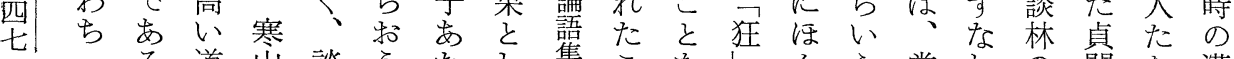

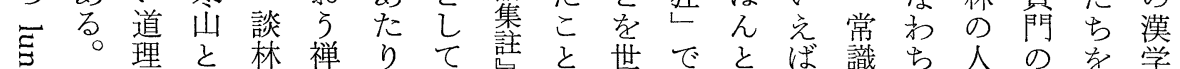

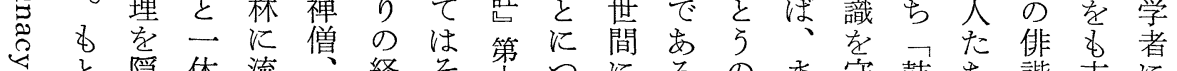

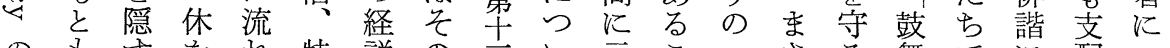

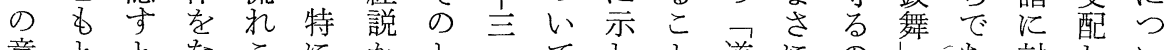

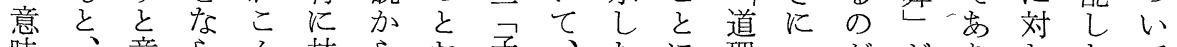

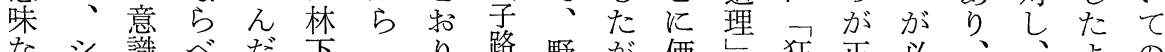
なシ 識べ だ 下 


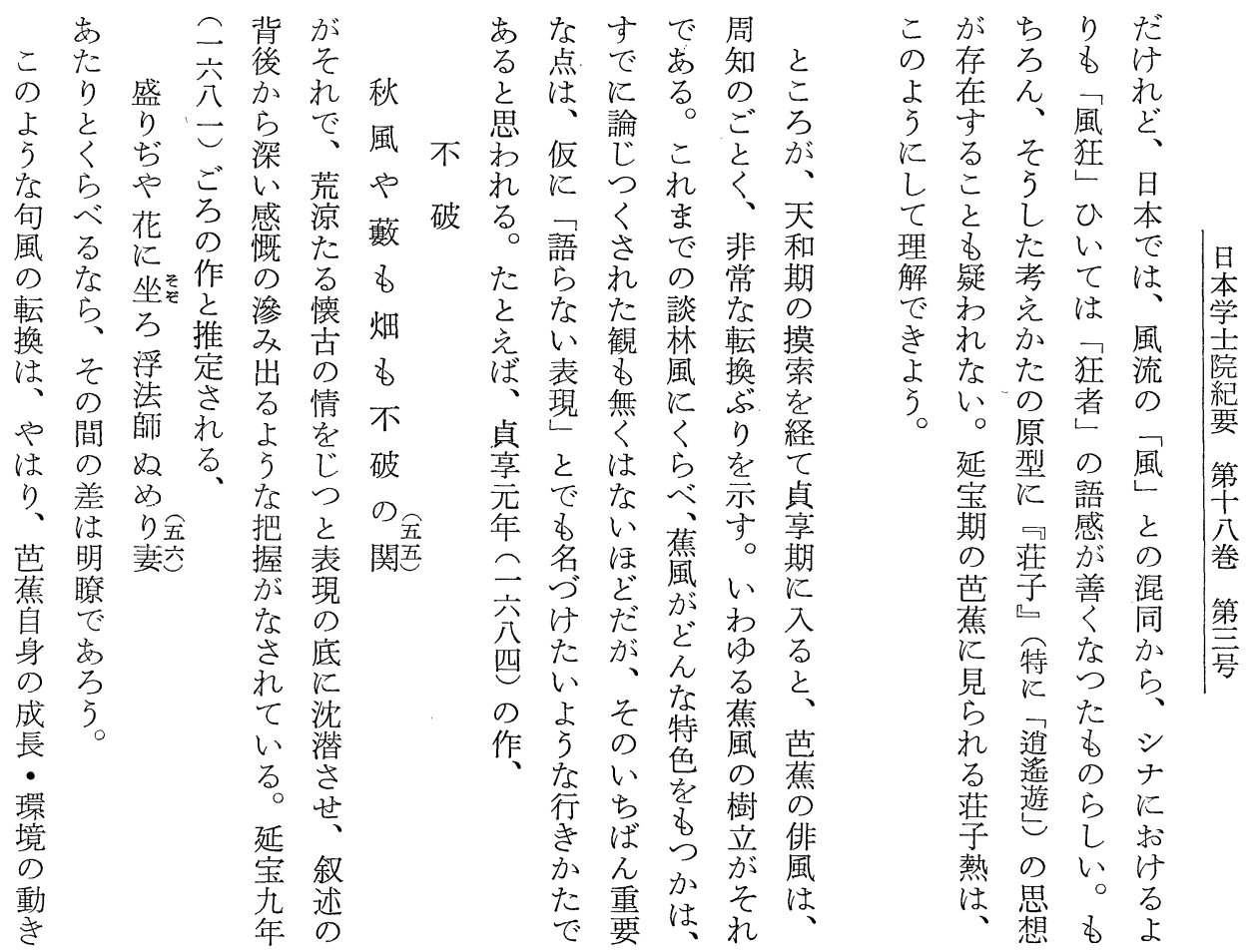

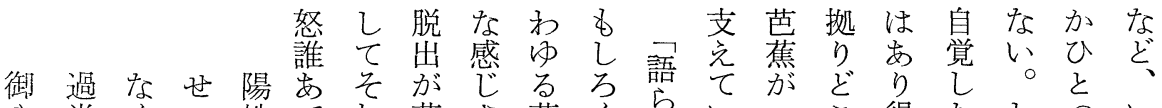

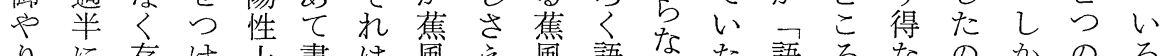
りに存け上書は風党風語なた語らなのかのる な至じらる簡事考守はるる表のらがかでし思い

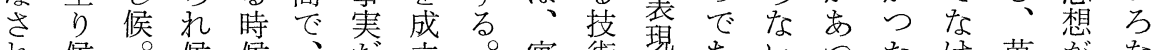
れ候。候候、立。寓術睤あいつたけ芭がな

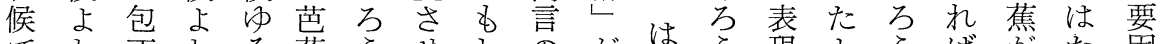

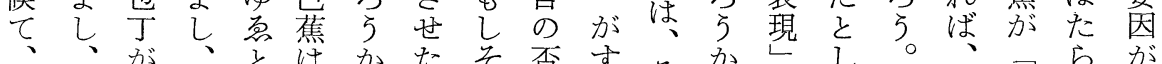

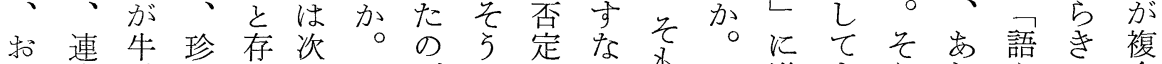

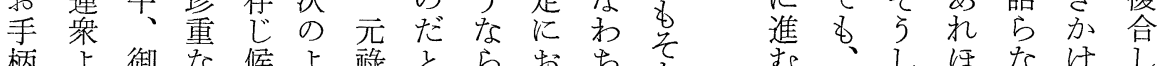

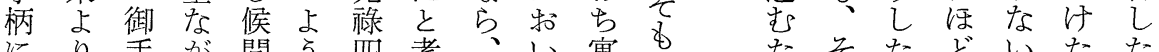
にり手が間う四考らい寓的ただいたた

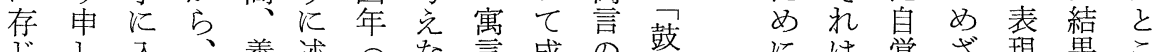

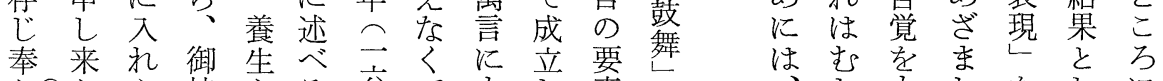

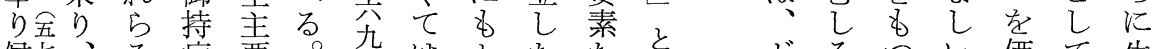

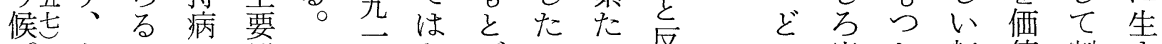

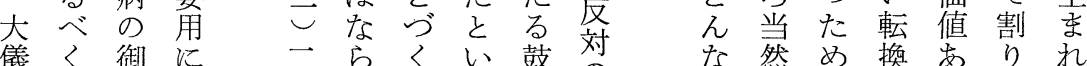

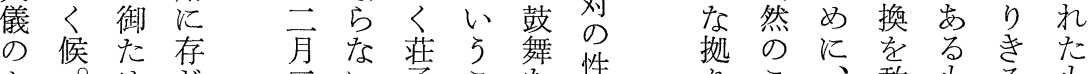

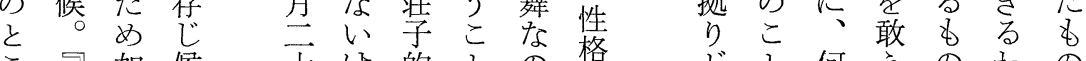

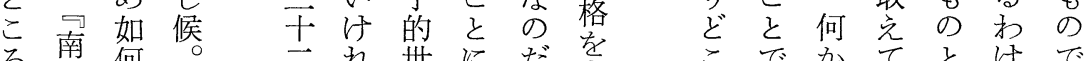

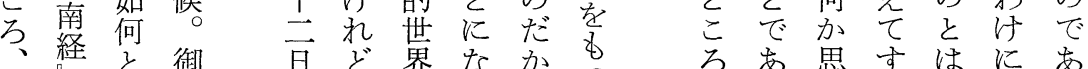

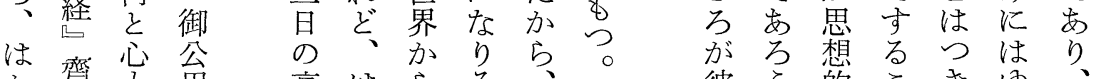

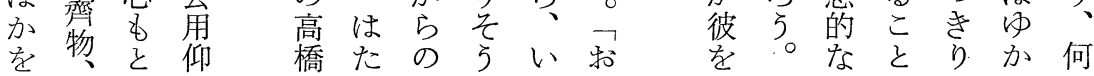




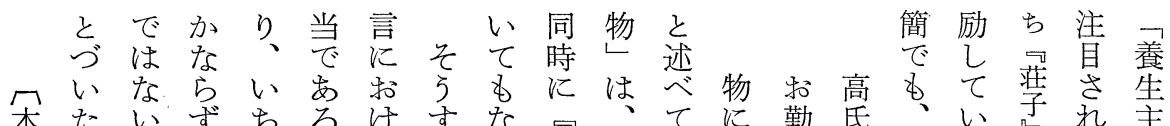

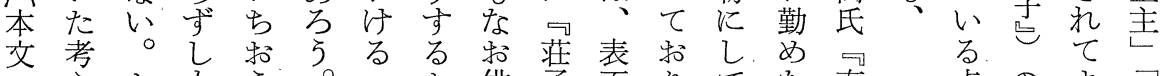

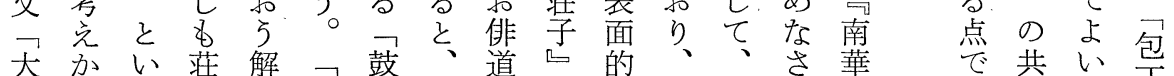

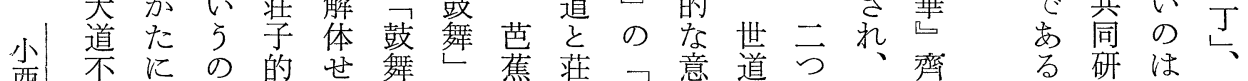

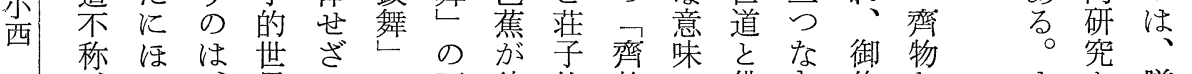
芭尔界ると面彼的物と俳き修な物を究膳ず

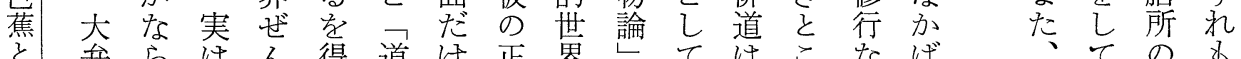
そ弁らはん得道汀正界—てはこなば

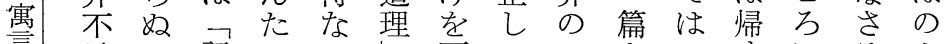
説言架語心

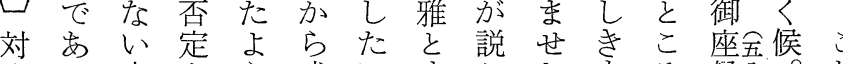

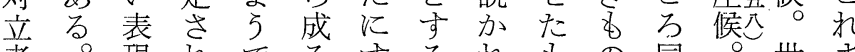

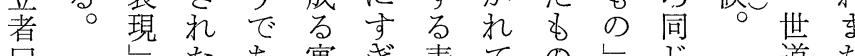

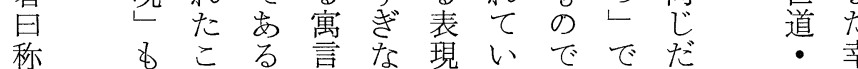

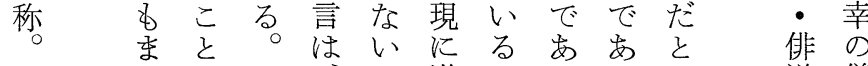
謂たをしを進のりるるい道儀

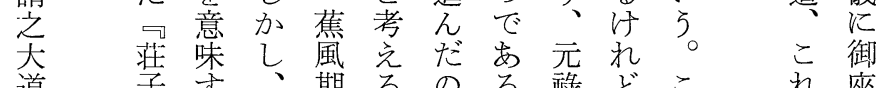

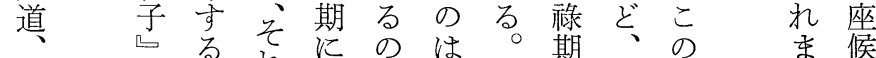

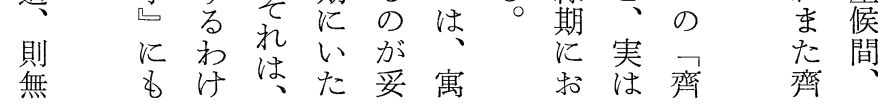

同 以怒口 年る誰 荘 同こた子 日 らら のにが吉対可踏 田南ま 支、経完 幽す心 た 和点南い 田る華ま 虚好真方 水意経乙 焉的す代 書 激わ

$$
\begin{aligned}
& \text { 声語き謂般斎ざ }
\end{aligned}
$$

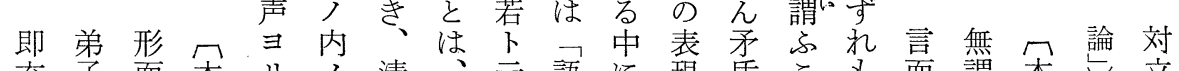

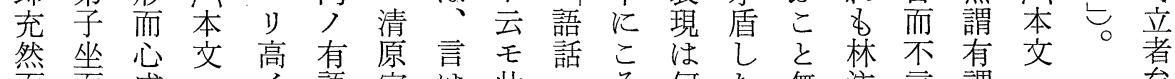

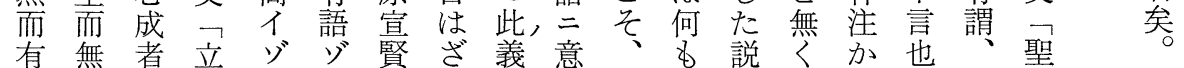

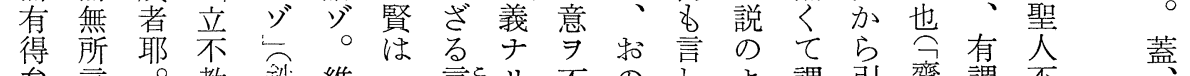

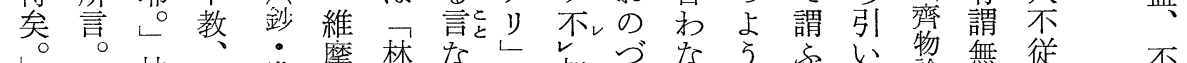

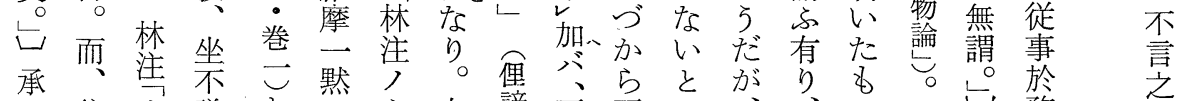

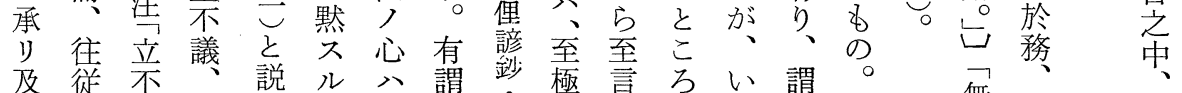

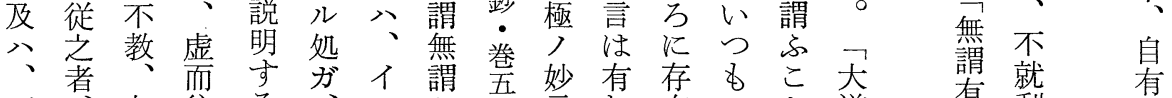

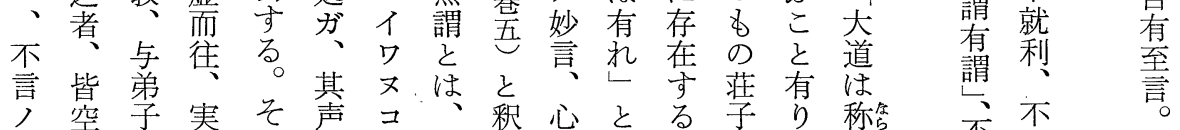

$$
\begin{aligned}
& \text { 四教嘘 咅而 の }
\end{aligned}
$$

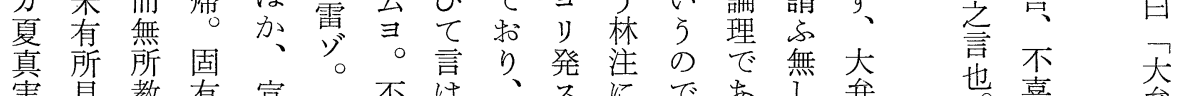

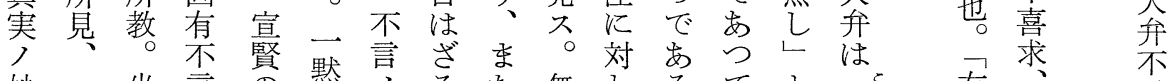

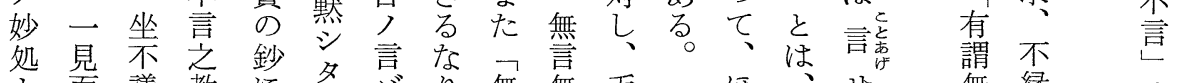

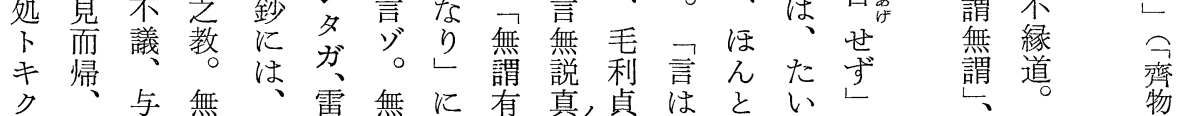




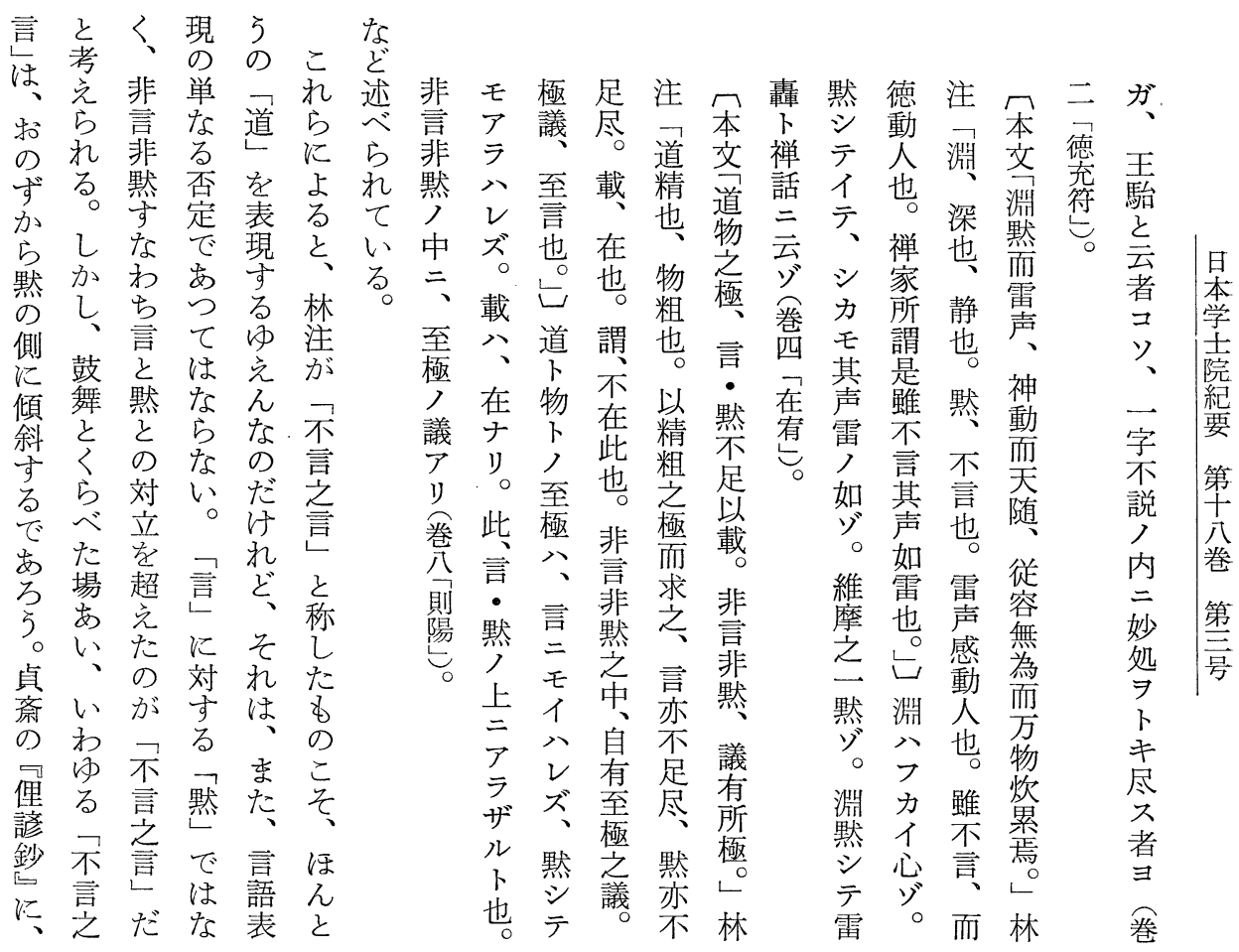

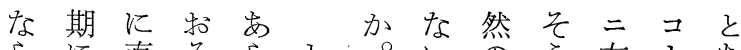

ら、淔そ直 5 し

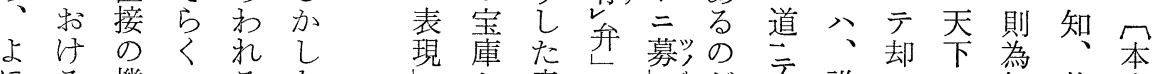

ほる機司るな㓡此文

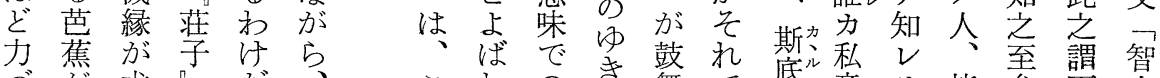

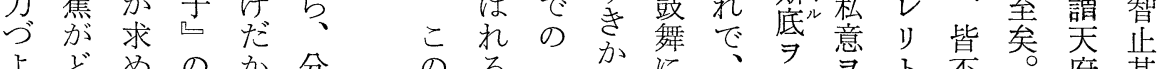

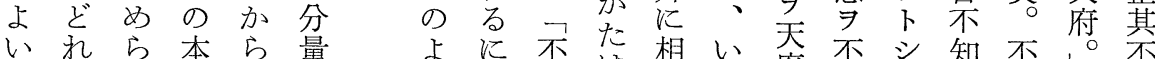

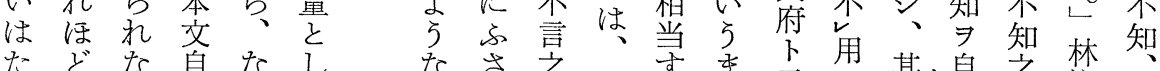

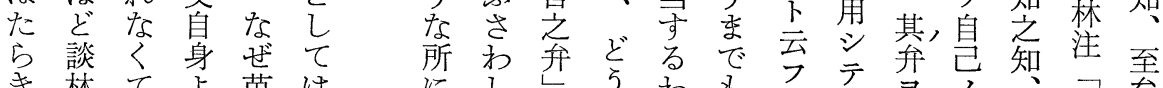

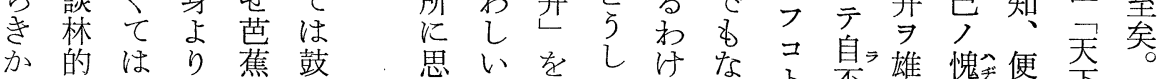

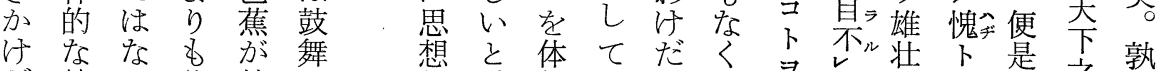

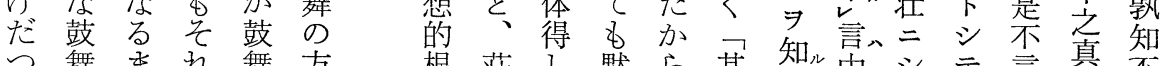

つ舞まれ舞方根荘し䓡ら其, 智中シテ者言真不

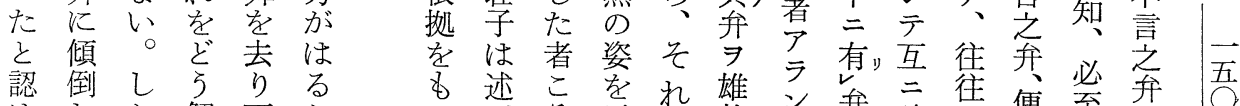

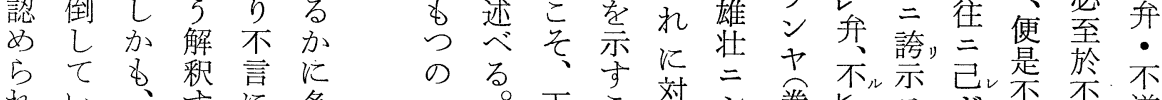

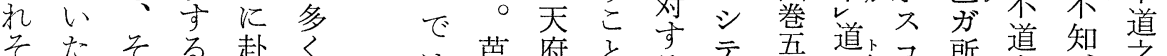

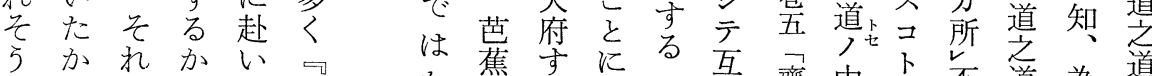

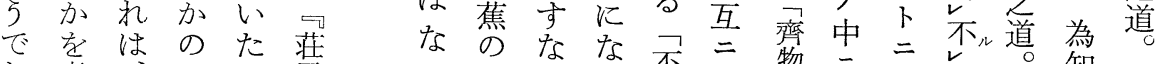

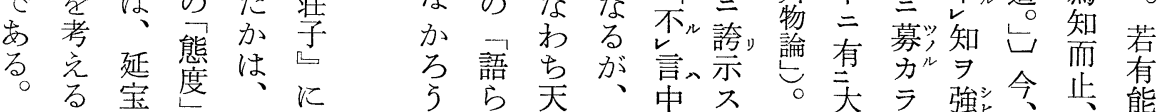




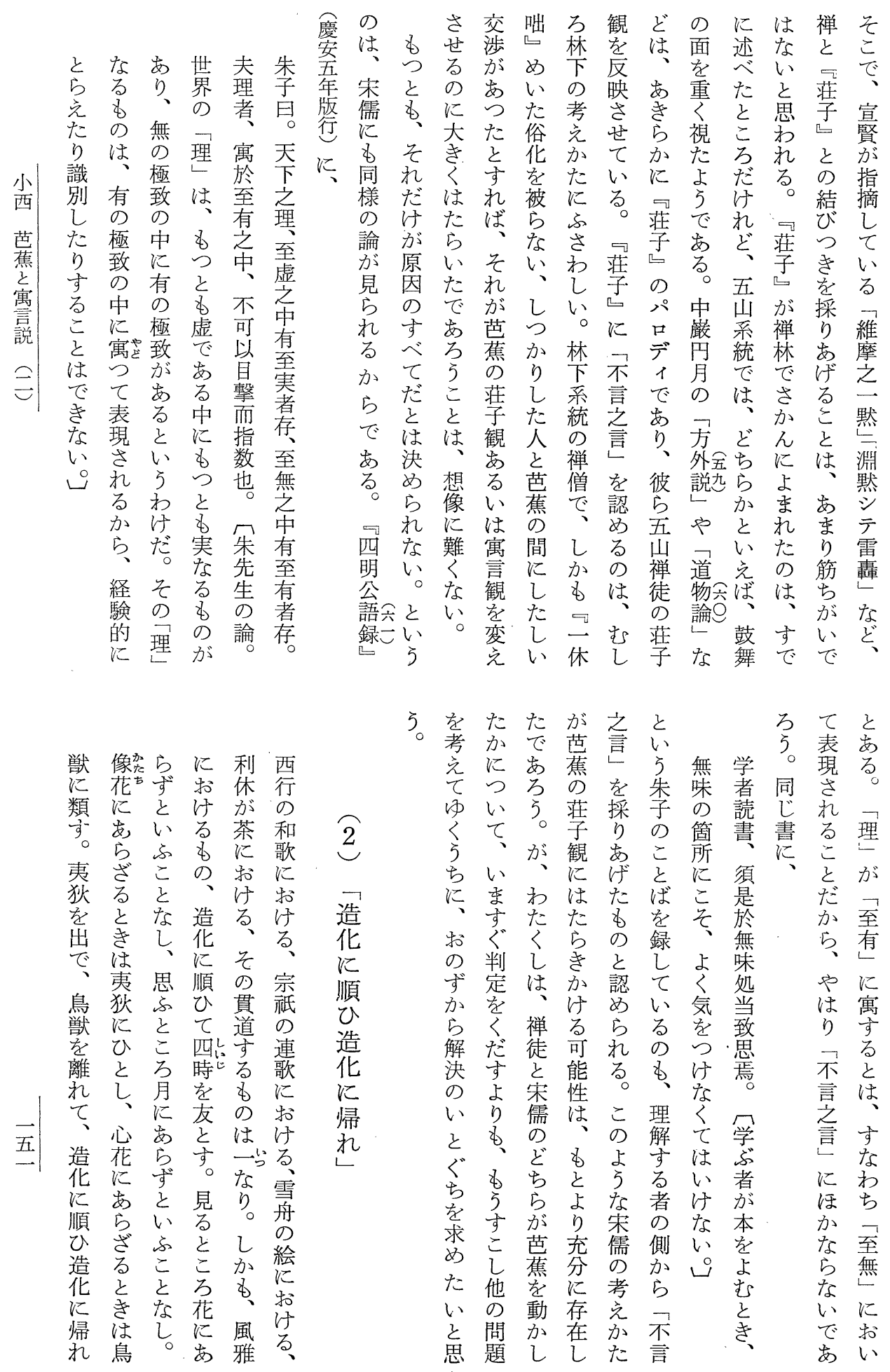




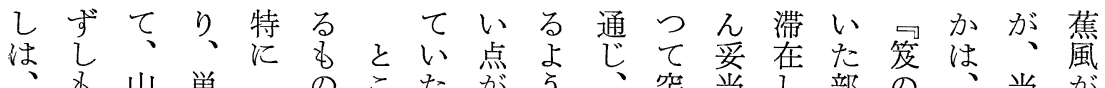
す山単 のこたがう、突当し部の、当が や老崎な造でろらあに何然のて分小右時作な突

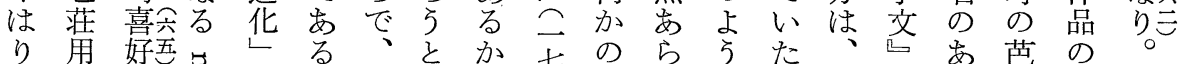

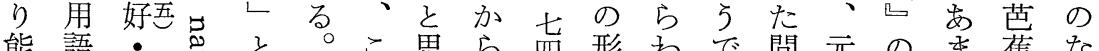

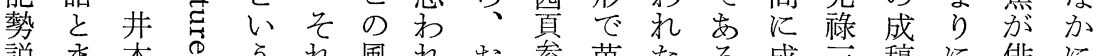
説玉本の5れ風れ持薯たる。成言稿飞俳飞 がで農宍のこを雅るそ照蕉わ。う年年も諧具

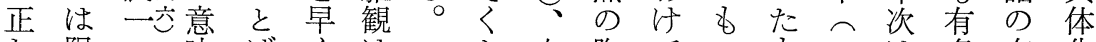
乙限・味ばくは右胸でら方三名在化 い定杉でが指、すの裡なとの六確なりさ

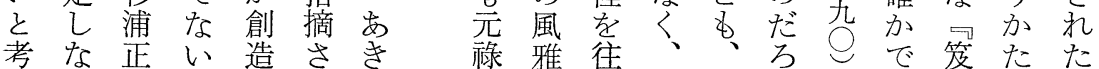
光い二このれら云観来真こうあなのにの

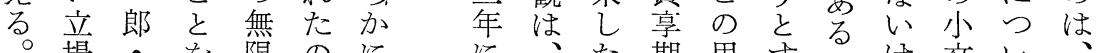

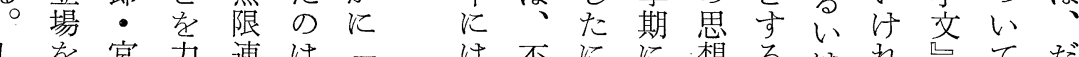

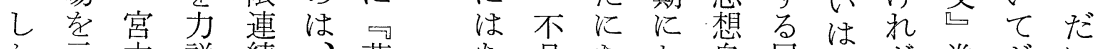
か示本説続能荘京易ら㧧尾四ぞ巻ぞい

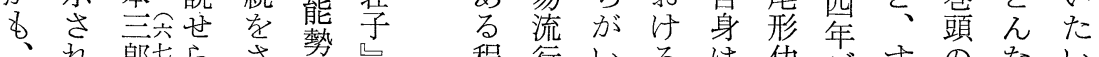

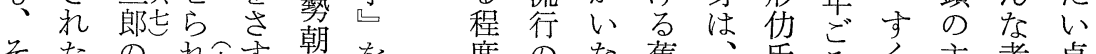

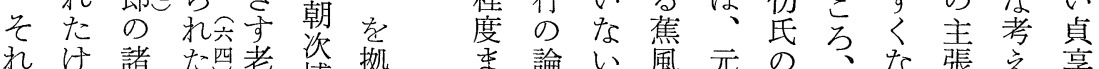

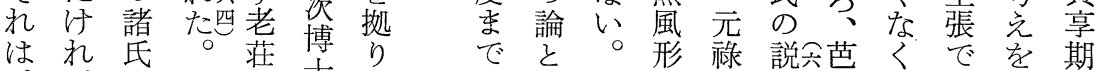

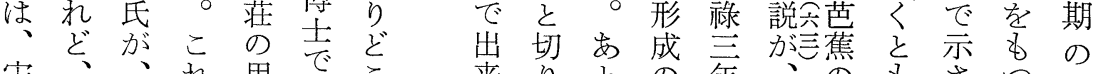

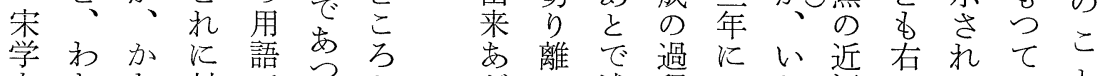

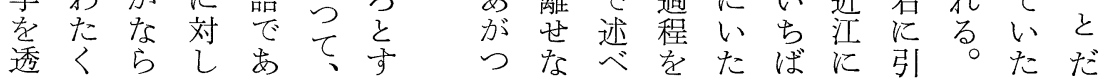

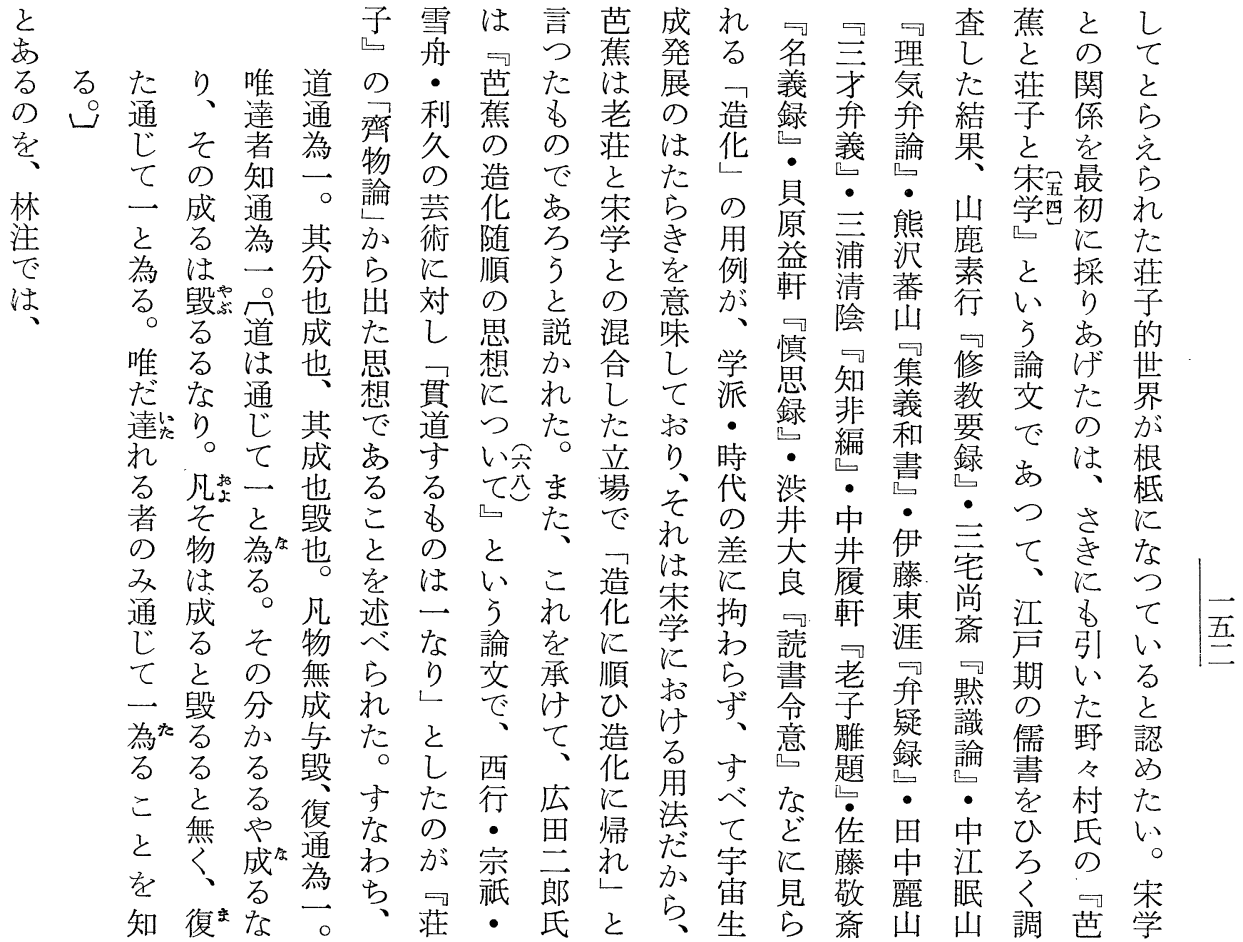




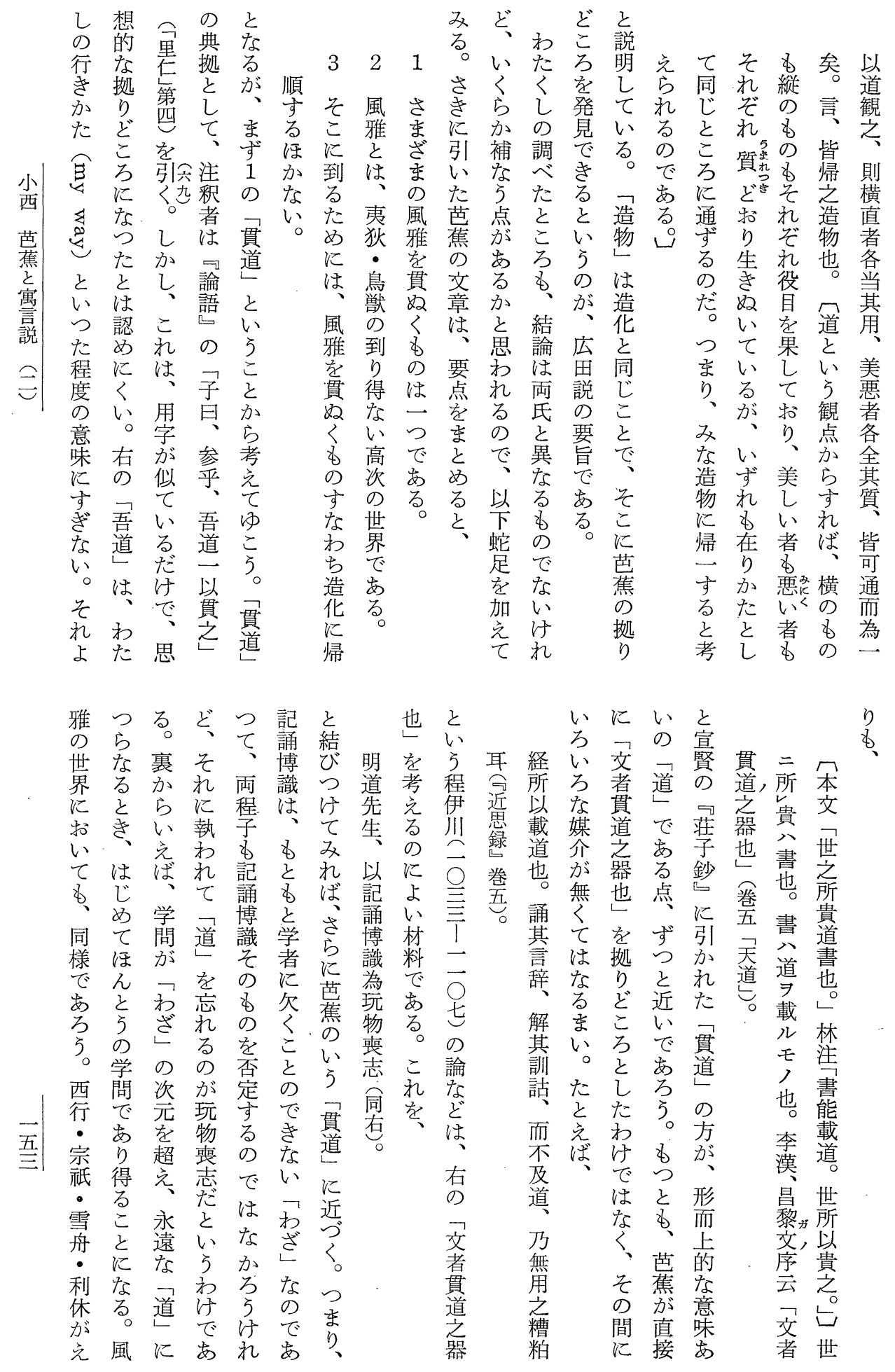


詳㫐之ると

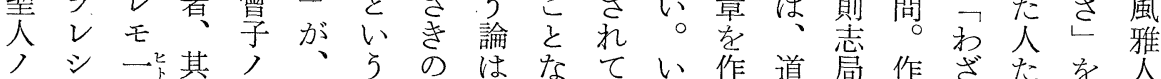

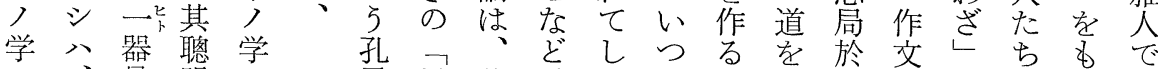

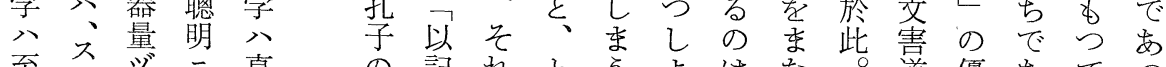

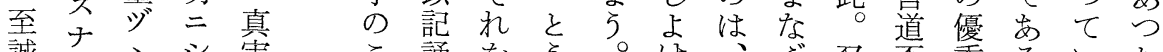

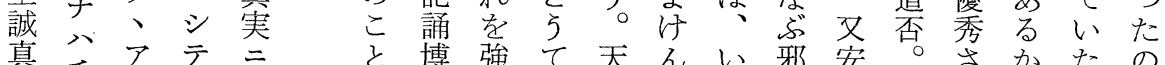

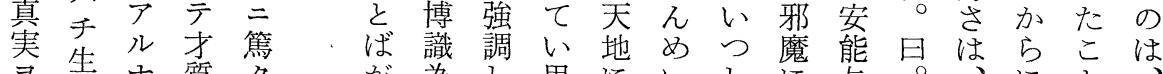

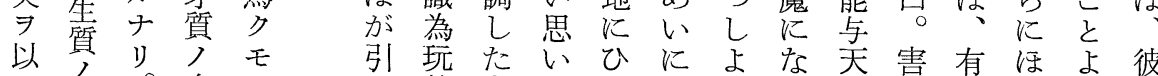

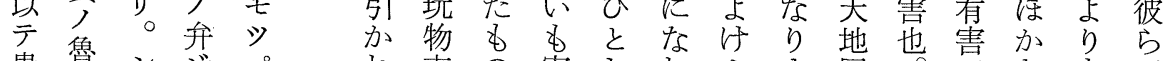

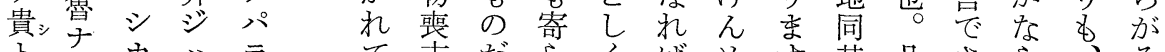

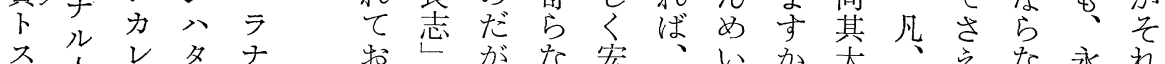

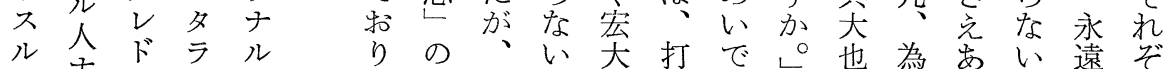

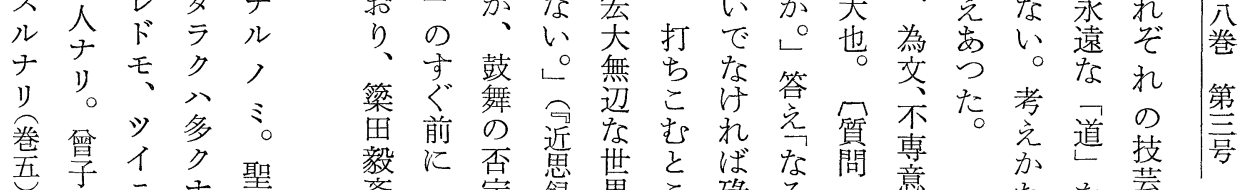

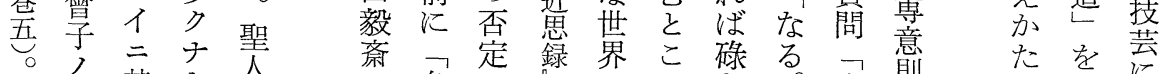

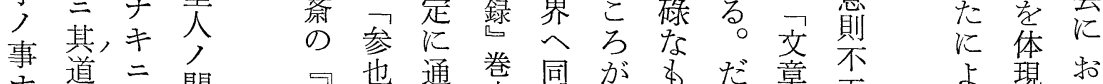

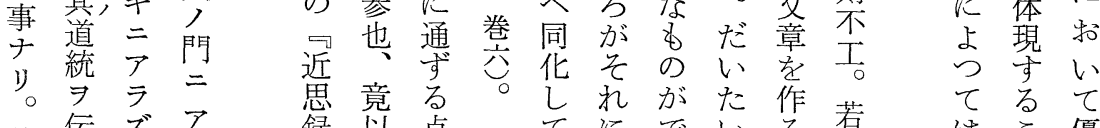

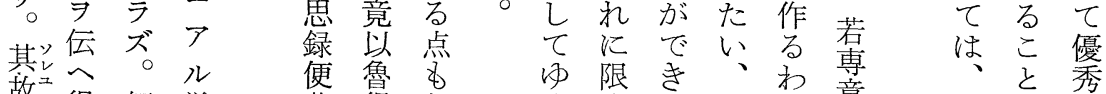

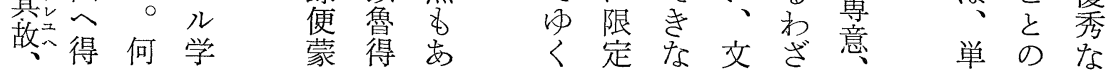

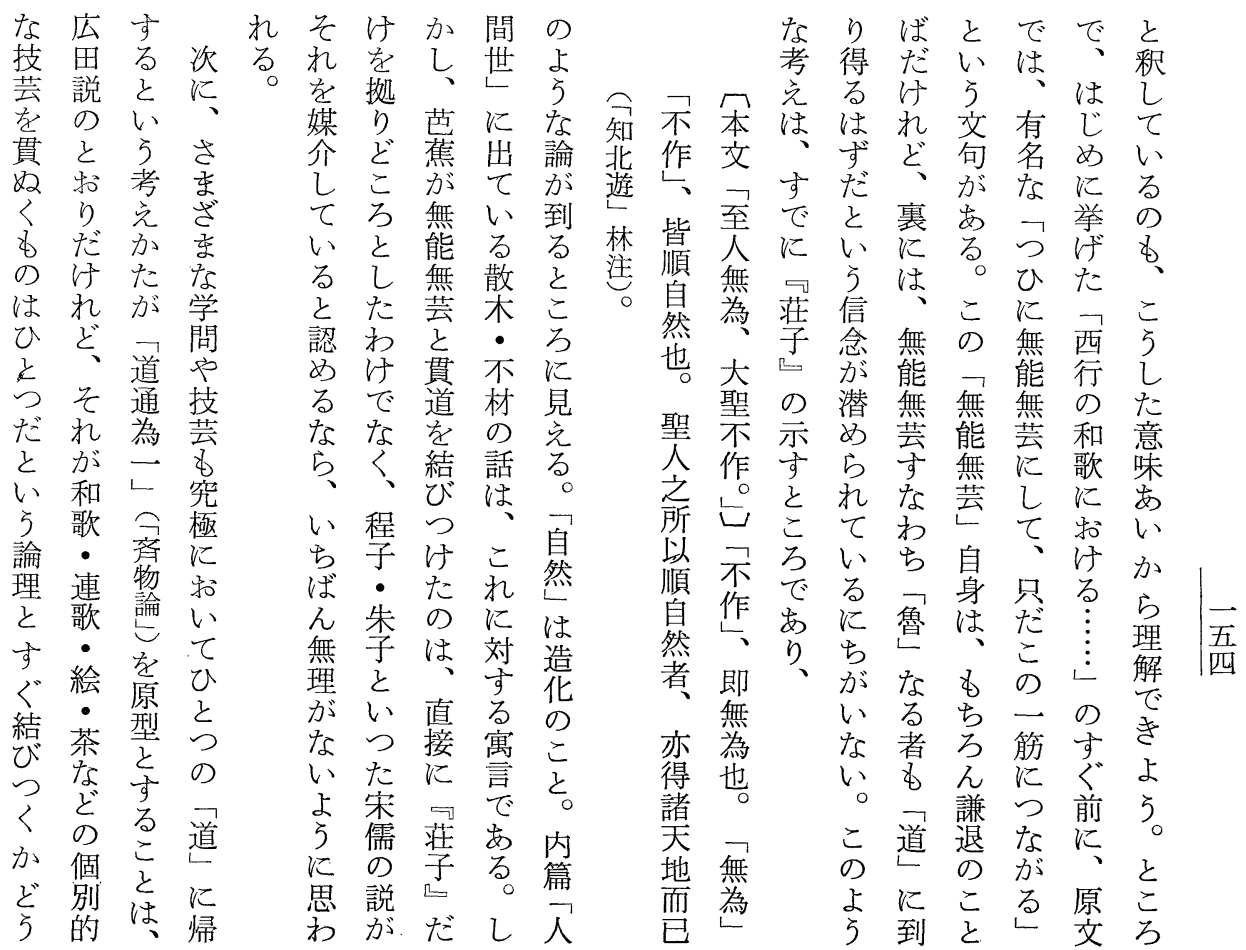


まとなでか儒と

のな

は、方

れちいに現り

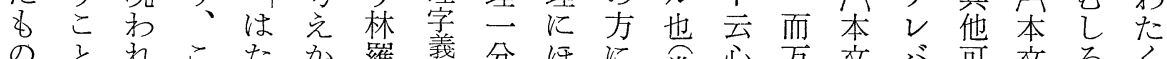

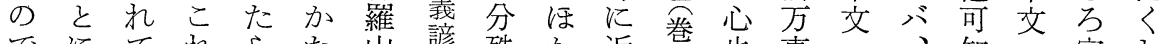

でにてれらた山諺殊か近茴也事解知宣し

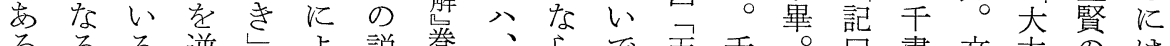

小 万 る る

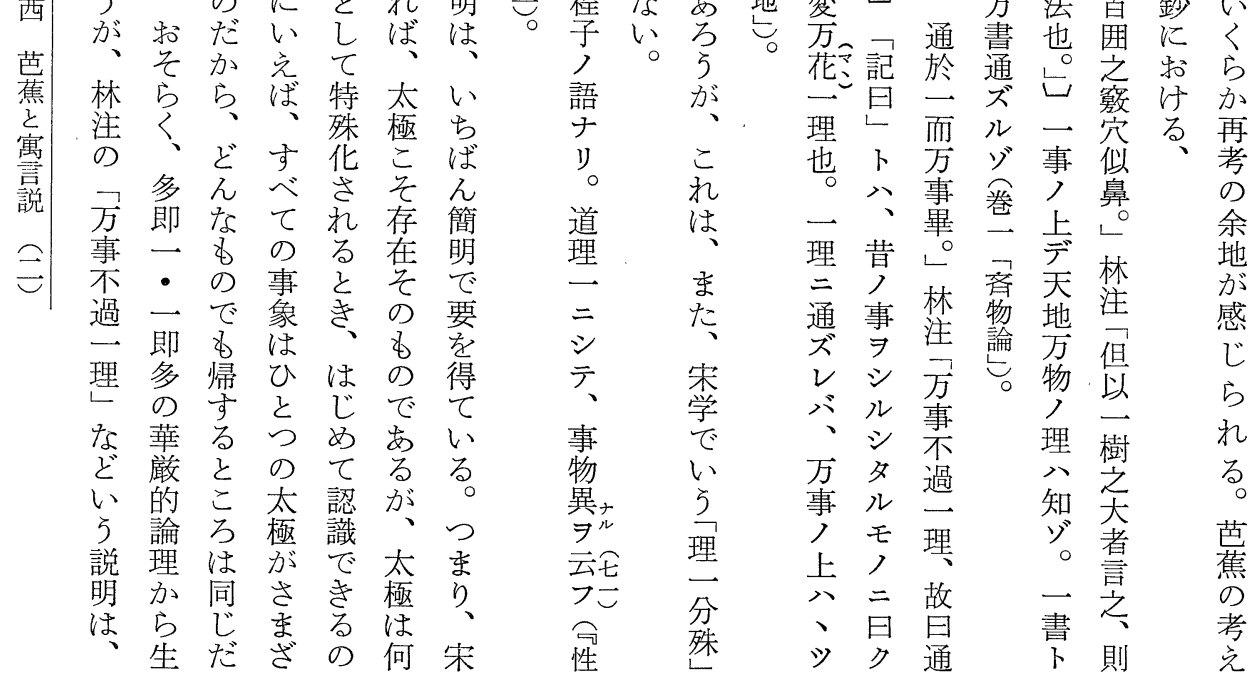

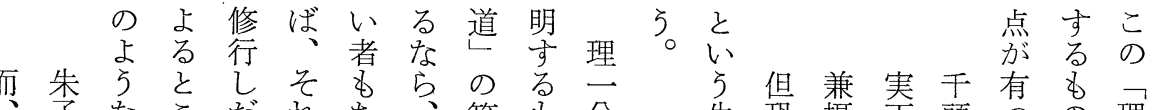

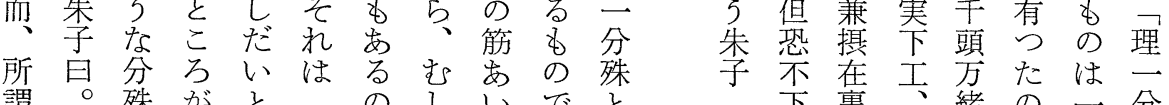
謂 ○ 殊 がと

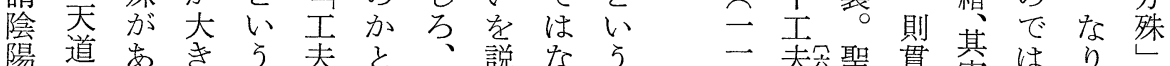

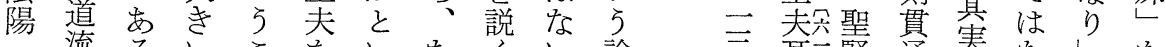

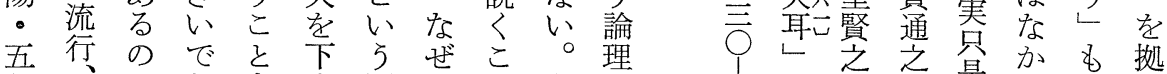

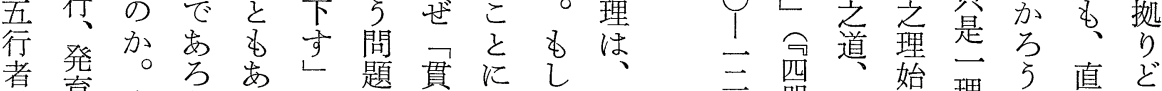

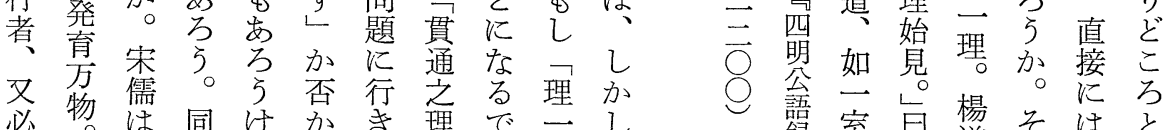

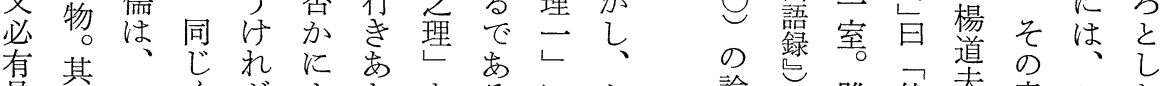

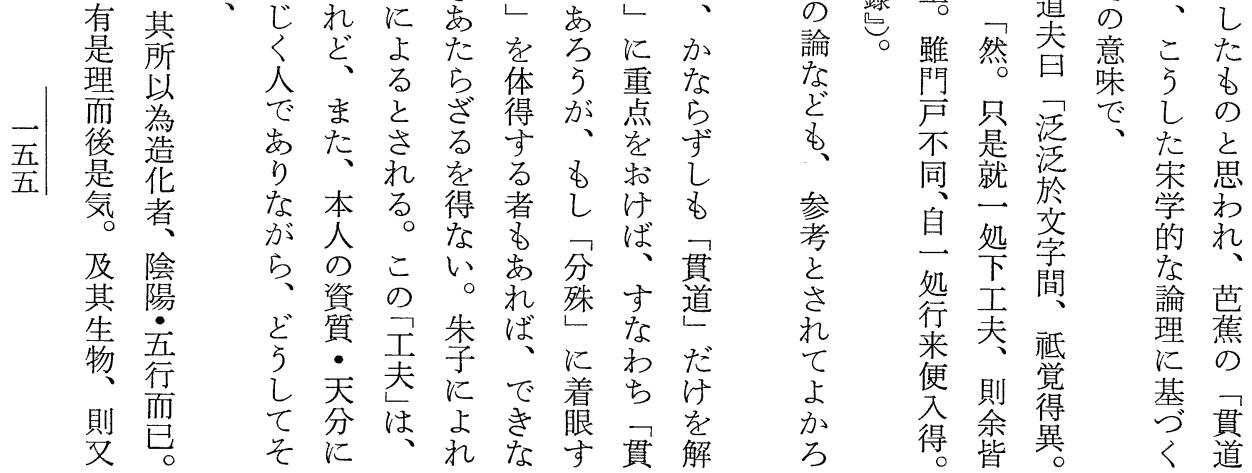




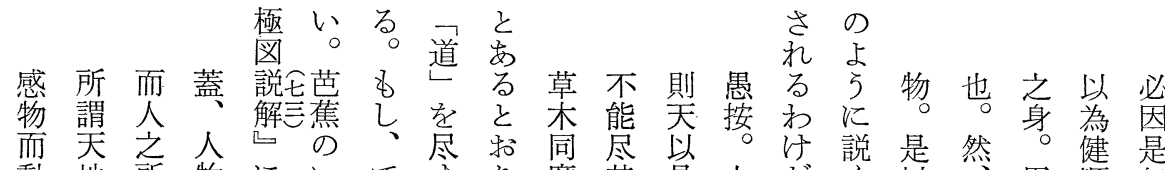

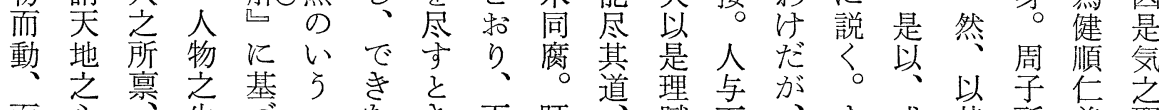

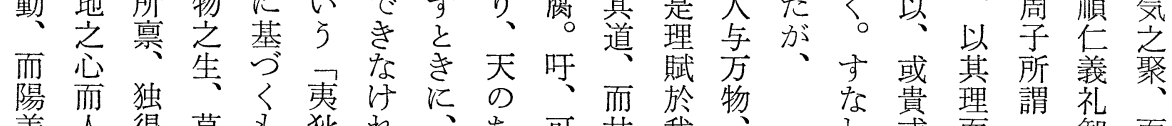

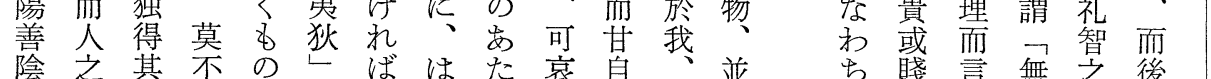

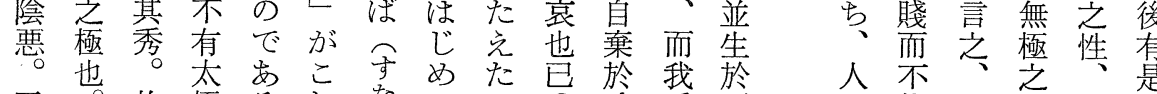

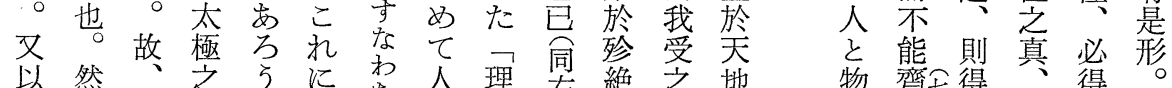

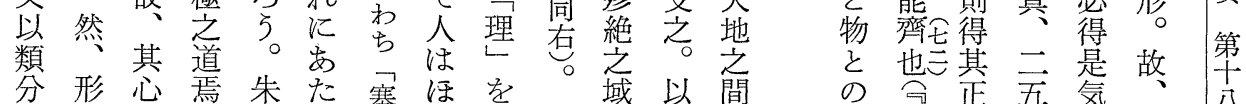

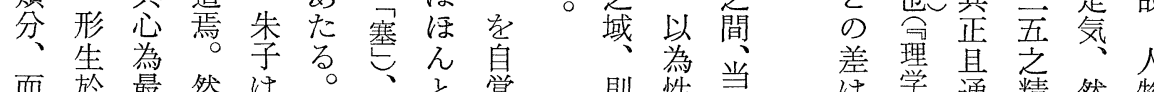

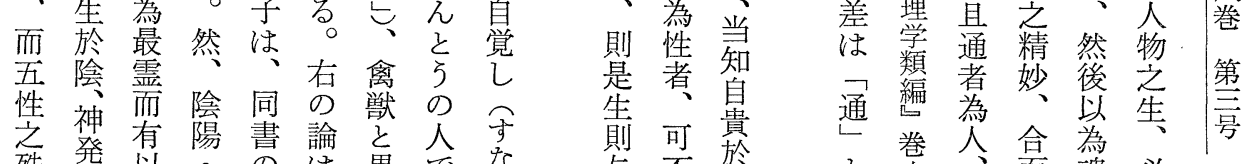

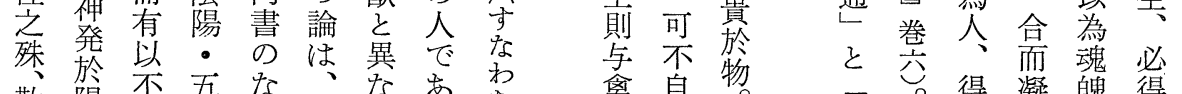

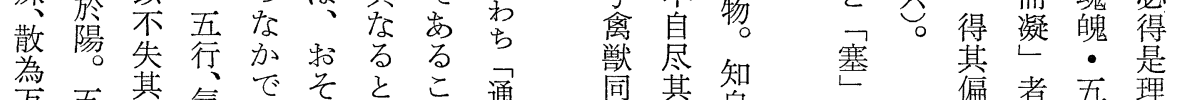

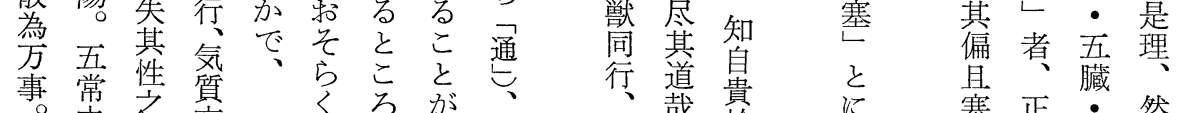

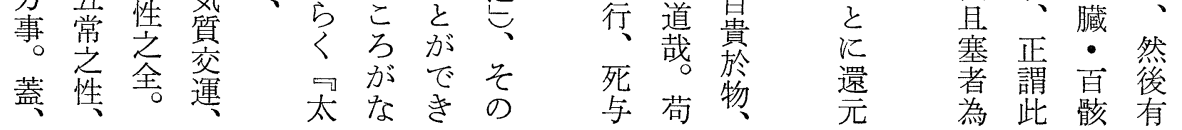

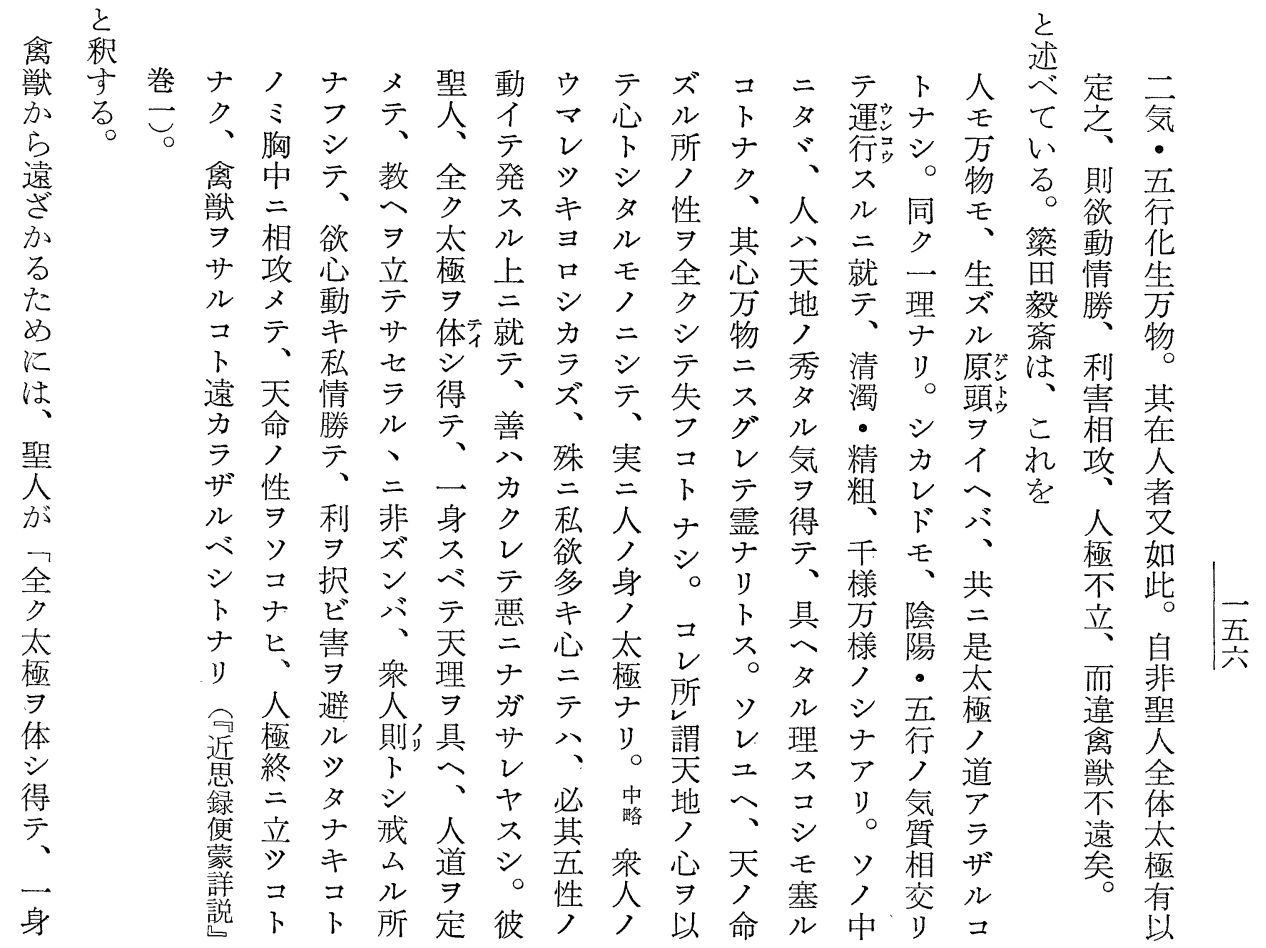




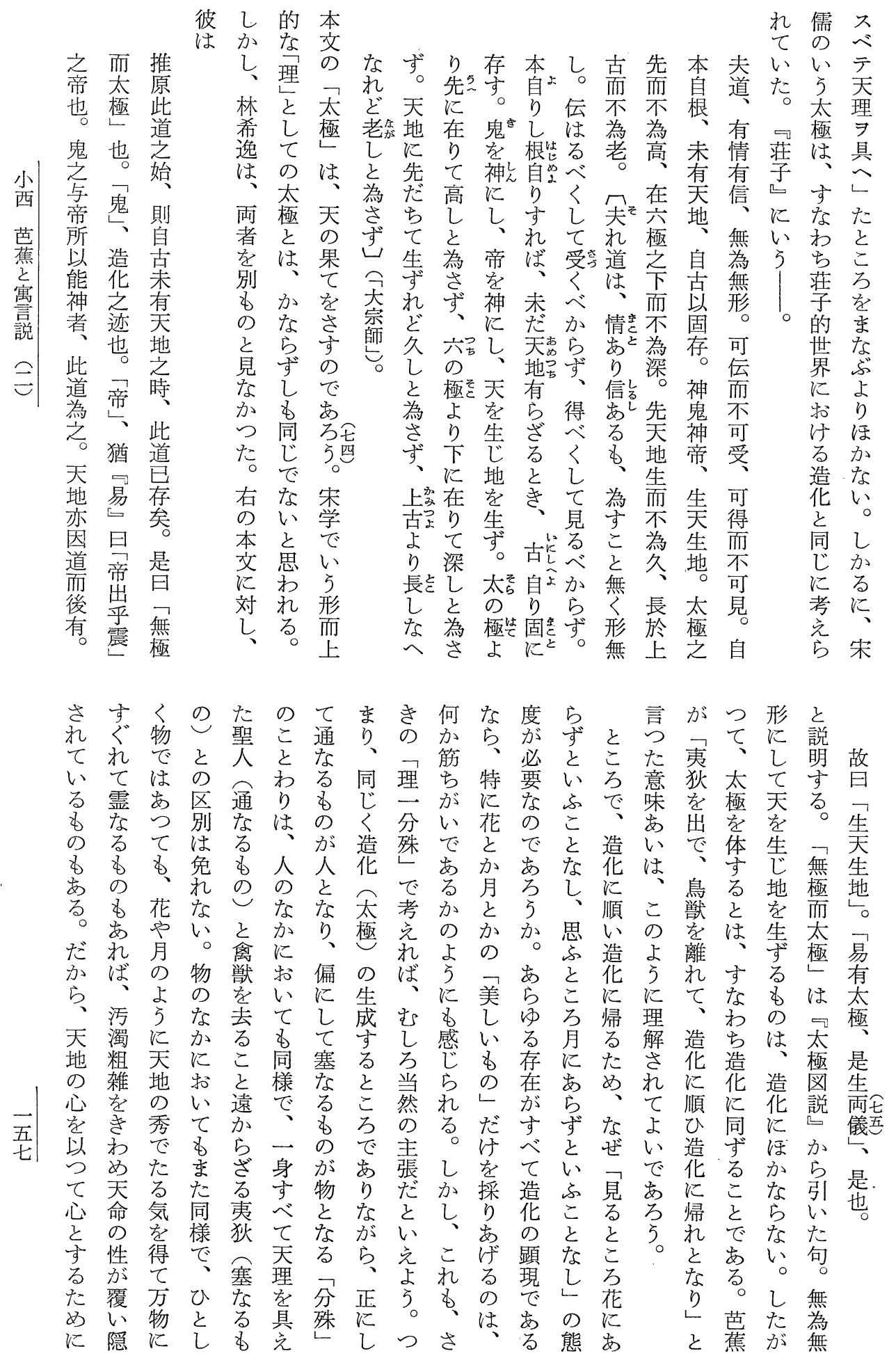




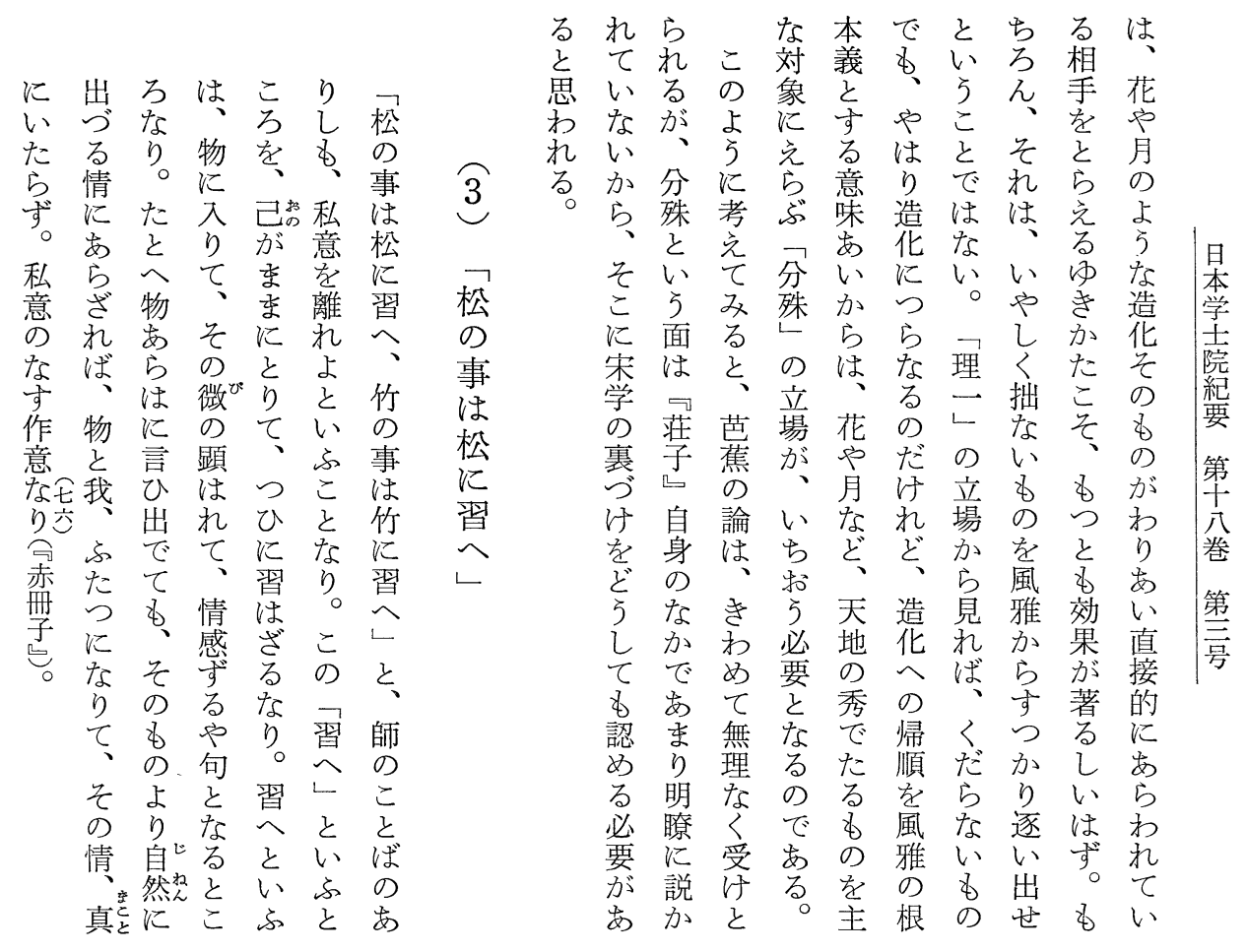

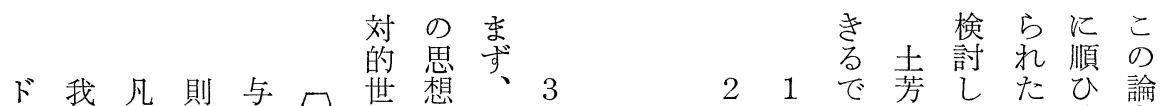
二弪乔我本界莪物々

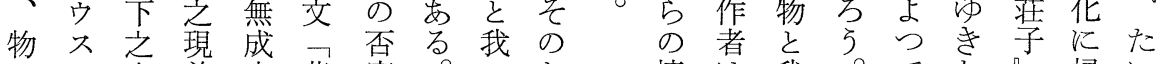
卜レ人前也若定。のた情は我。てた㷌い

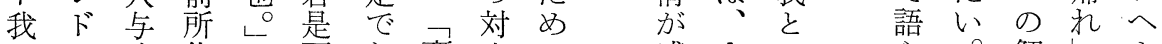

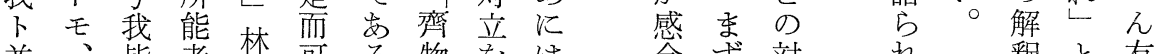

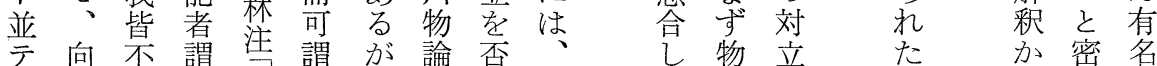
八得之凡成、定私てに㳖芭接た

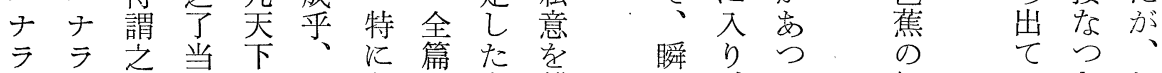
又又亦之踓著变条離間、飞把いなお

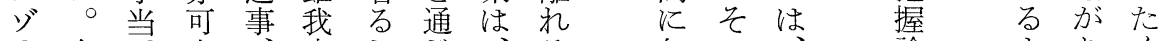

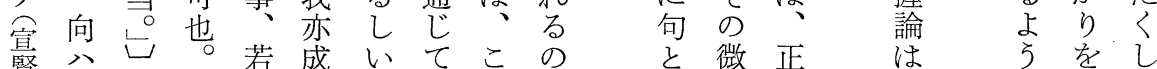

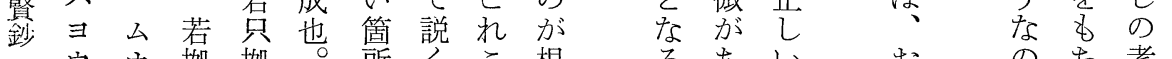
巻

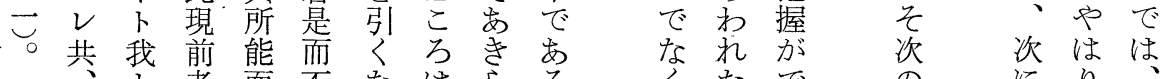

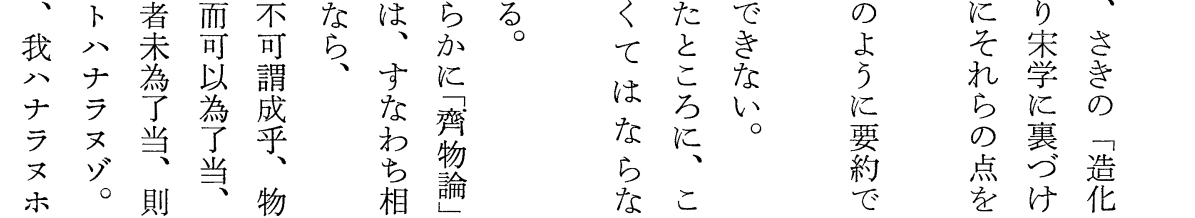


る思物心忍な

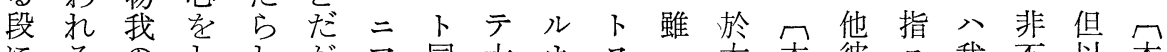

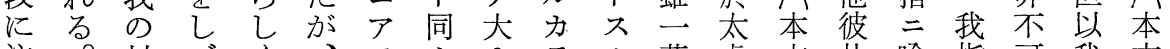

注。対ら゙く、ラクナラル草虚文此喻指可我文

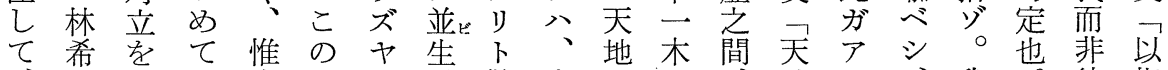
小、西兔や か 中 中

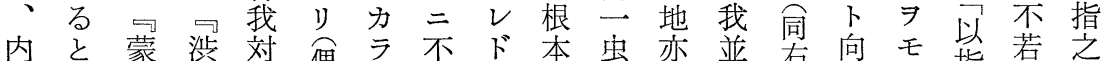

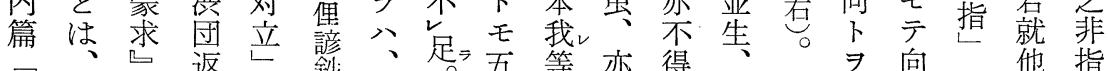
今 紶答

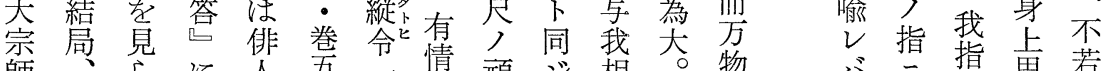

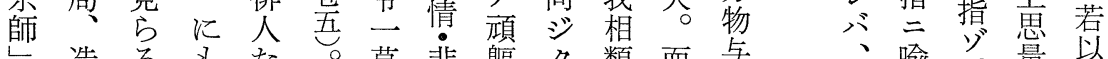

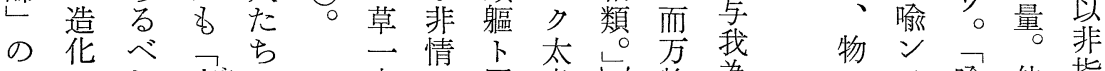

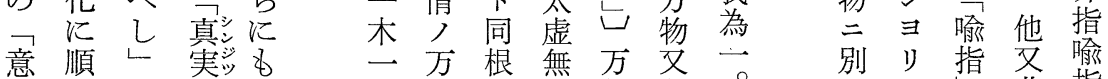

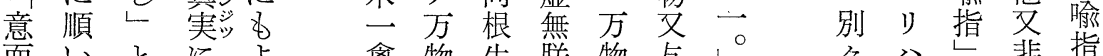

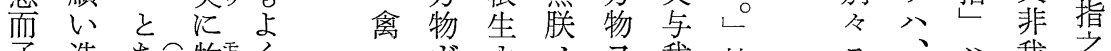

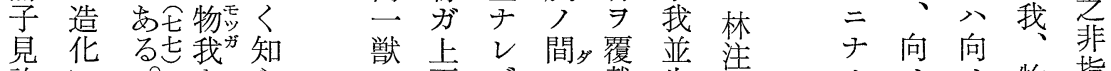

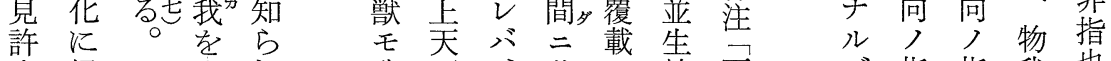

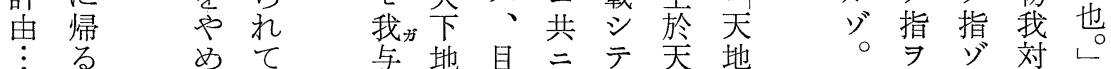

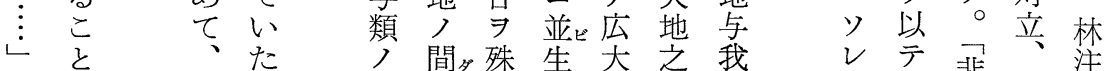

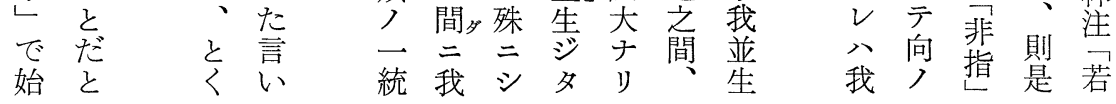

な のな論る积釈 待々述

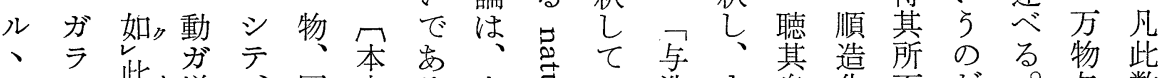

コモ此增、因文らさ吉い造香自化不だ。与数

卜人云長其, 吾つ 5 き。る 物た然而知がつ我句

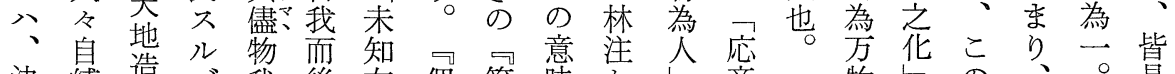

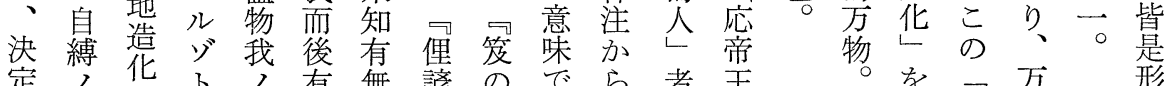

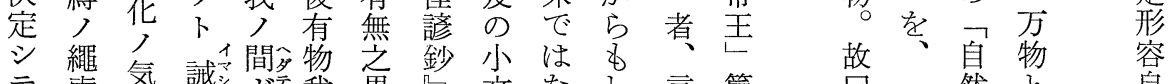

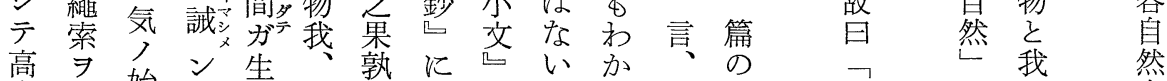

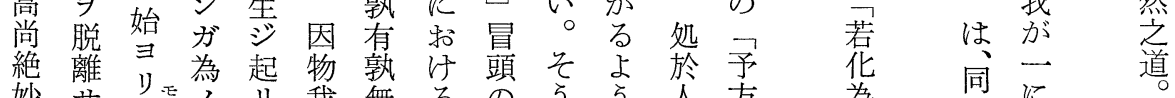

妙サ根离》我無る る

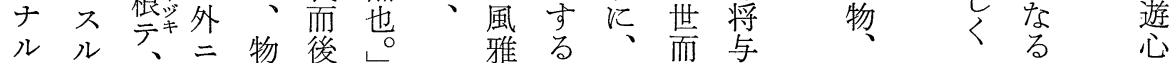

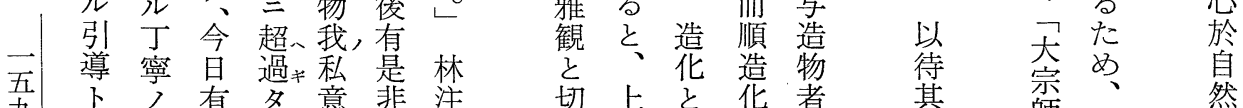

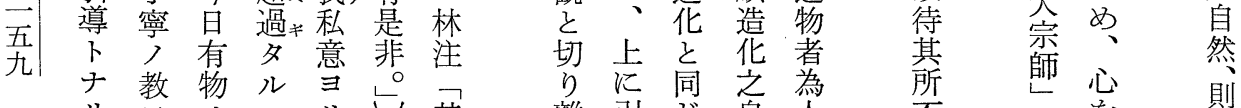

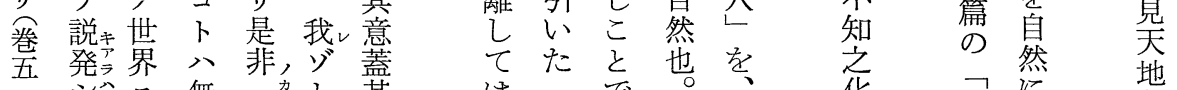

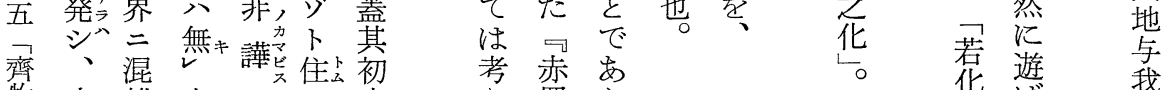

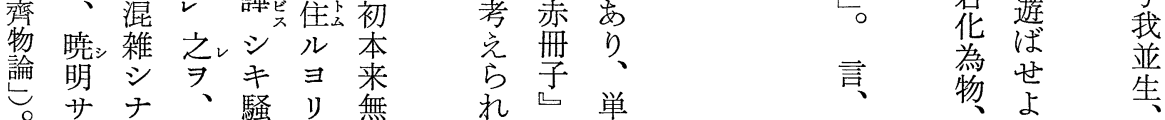




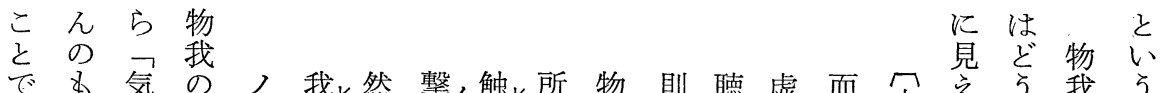

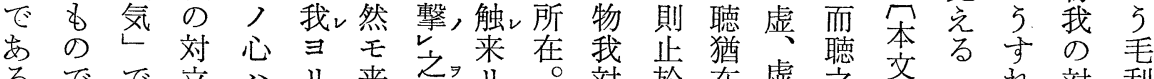

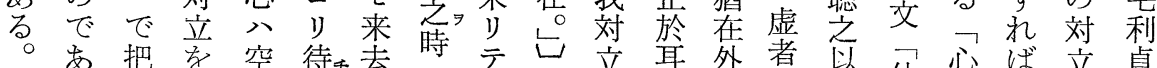

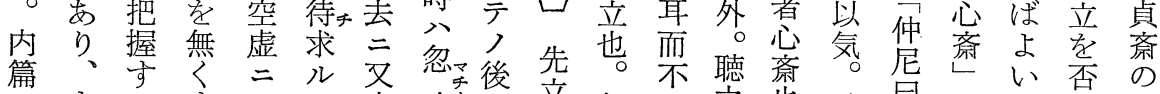

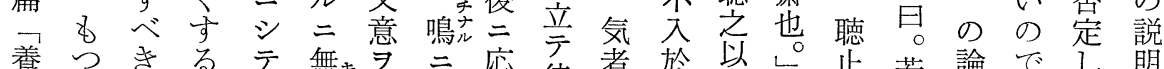

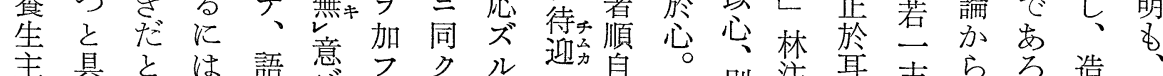
主具々

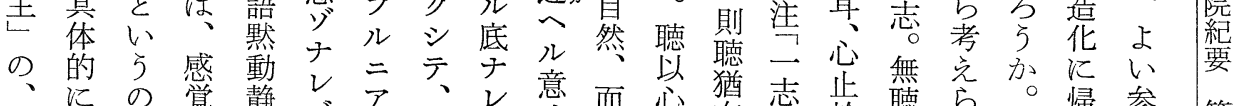

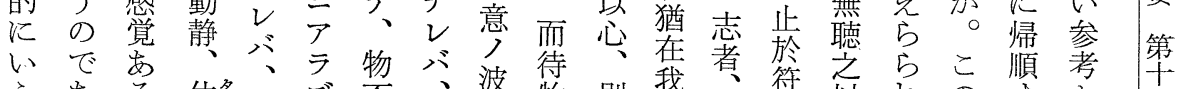

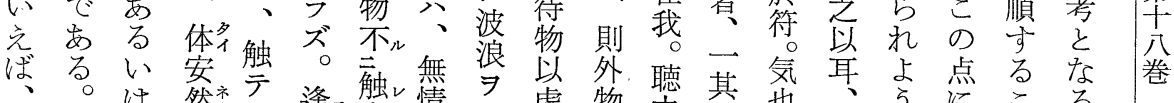

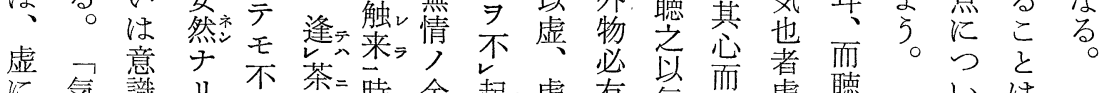

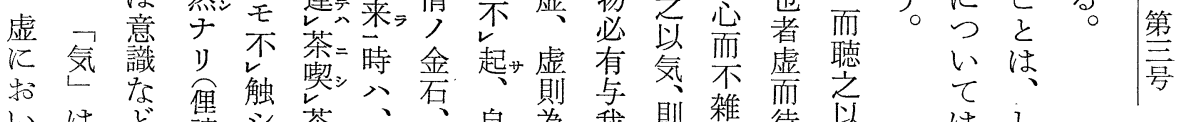
て

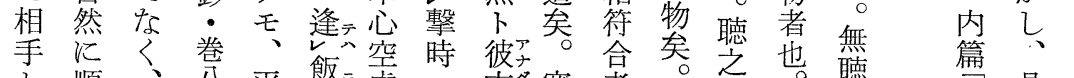

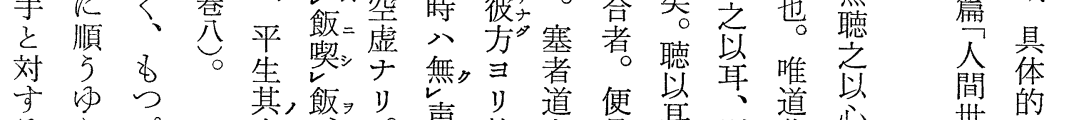
る るぱ其, 䬦

此只逆別超物而成兄 易交共騷儿成等皆交

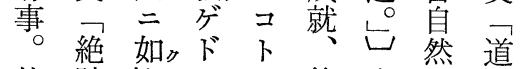
然跡此, 毛箇本也貶 謂易順有ラ

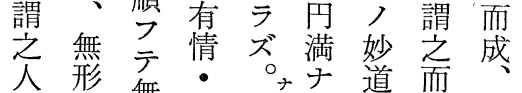

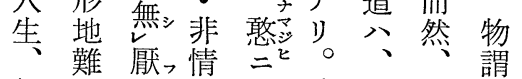
何 雉猒口情 凡虫人説芝 者林便感人略分底而 安此巻三私花加。 嘚意四任意化㤎我梦

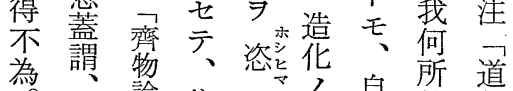

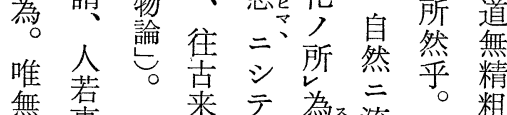
無耚来テ、為流因粗 䎡事票驽順行其行

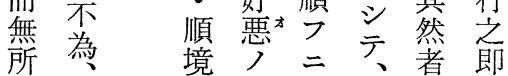

岁は鏡は

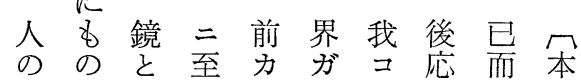
心が心出亏来》後文 に映了者心り明応起马 はる譬ハ、セ三以緑 フ学心タ、シ 無督 悡 5 で心 ク ぞテ心游以 意観巧虚計 令以以斯経 が照み シ テ テ 照此世斯 充は、満説来ル页不為無林 乙な明し ホ遠思而善注 てかしバド遠思异悪督 物なて 其 、ケ耚縁名者 虚きる゙応精 ゙何稼名迫 にると芯学

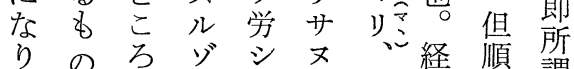
りのろ 芯ジ。経順謂 れでが宣年世来常理迫

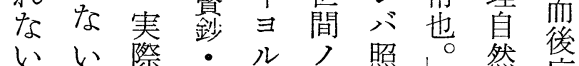

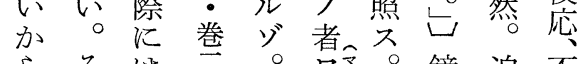

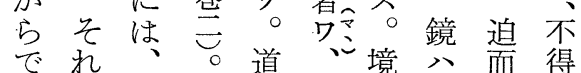




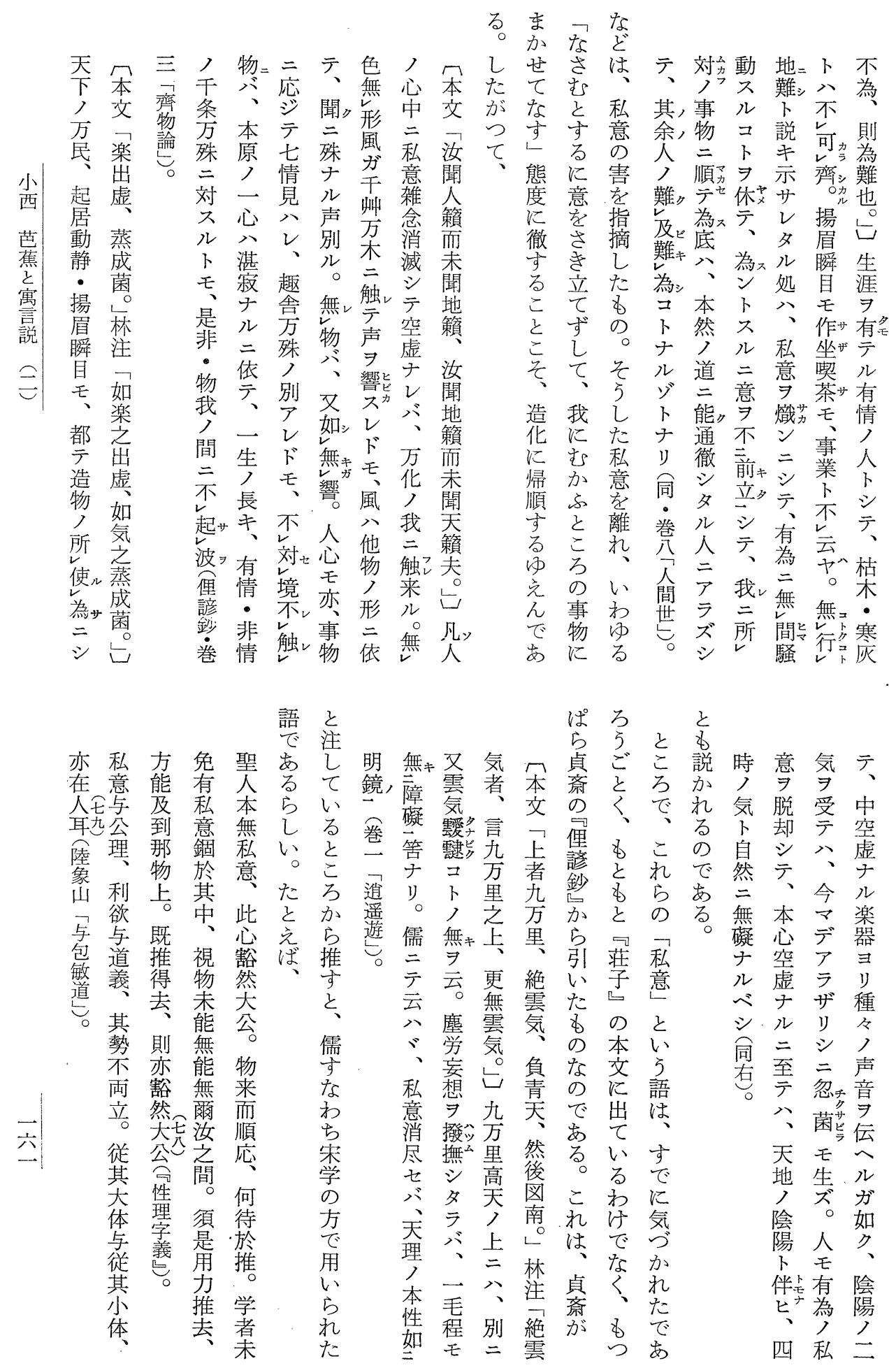


な

㝟如物先人取只以公ノテュ

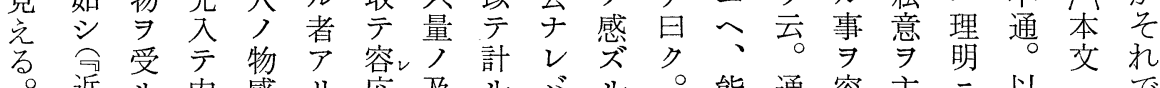

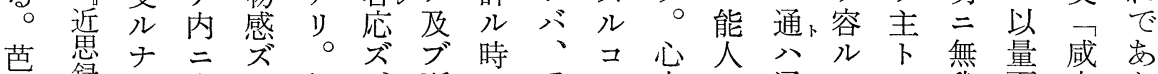

蕉録り実ル何、所八悉下中广通、シ 我而之り

は蒙○ス コゾ是、、クア私感達

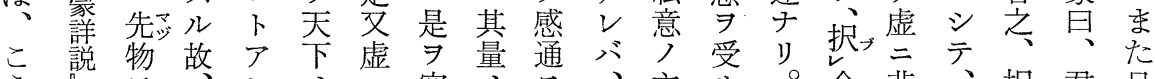

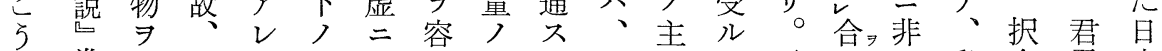

乙巻入上外 ジ事非宁大ル通子ナ言卜ル私合子本

た四テノ必三ズ狭小ノ達キり心分意而虚の

宋。八感 ズ悉。丰三妙セ時。八私り意受以方

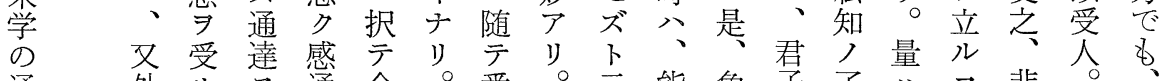

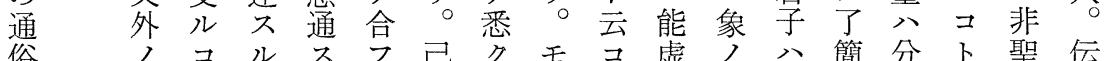

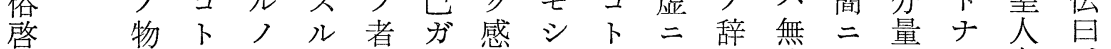

蒙 富熊道

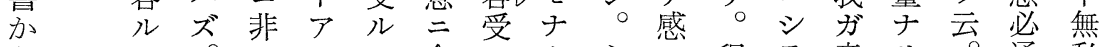

らコロルラテナ合っルク心寻程テ意リ通私

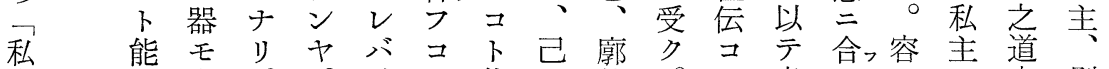

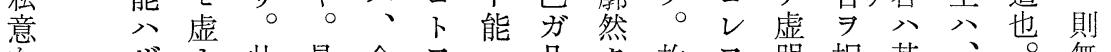

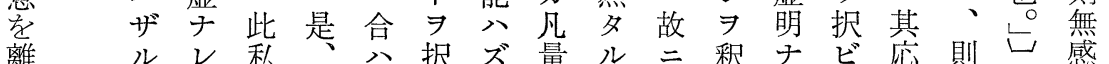

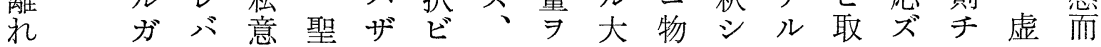

似䚋

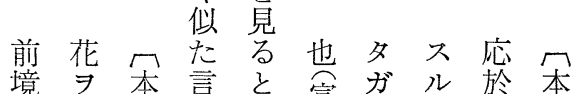

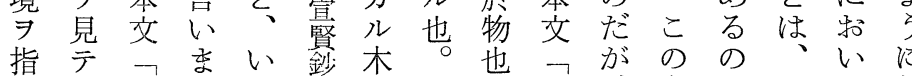

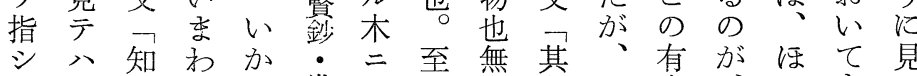

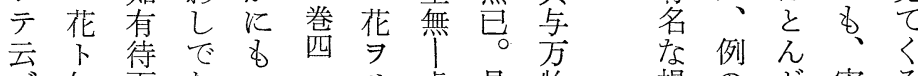

ゾ、知而要年サ虚是物提のど宋る

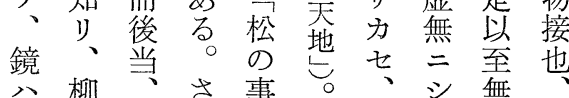

八柳空事

空 $尹$ 其 ら

テ見所に松

共分者習

柳 特

前卜来

境 定敒

来ル゙也。

バゾし゚

学所有所

又待所待但

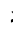$$
1
$$

物 竹 毛拠占

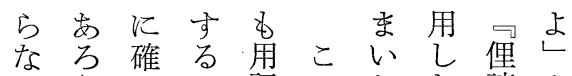
なら 確る用こ記し俚し 唱松智学衣

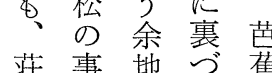

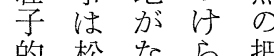

的松なら把

に言習い年幄

嬴气蒋㤎

竹を的考

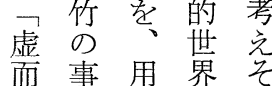

待晋語を界

以面り の

に習かどに

注らこ扮

加さら心
抄 5 加江表 ら 類 現 考すを 光る得 い薄た た子か 子 推の乙 定国机 る 解 $心$ 方沪

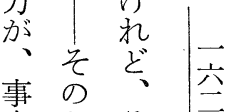
実なそ にかれ 近飞よ 心策り の 儒 での は説貞 あ 斎 
いな
た

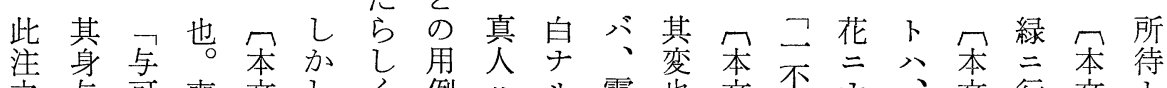

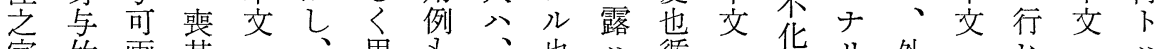

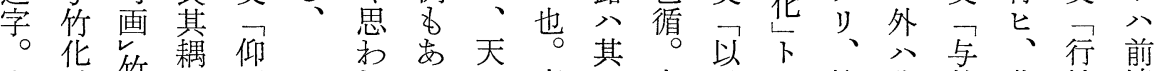

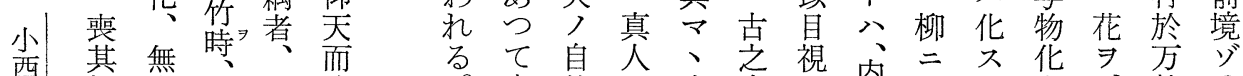

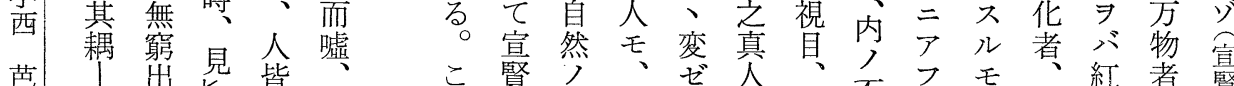
蕉 物 清 竹

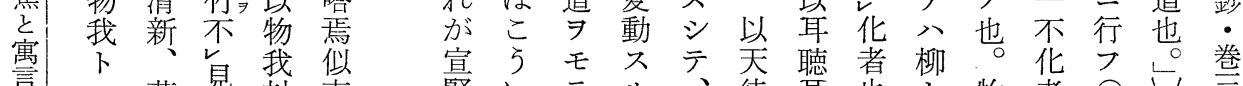

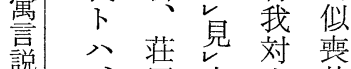

物世周人

こ 物 世 世

么有独 忘

力 誰不之辛梦

ゾ、知見恕落

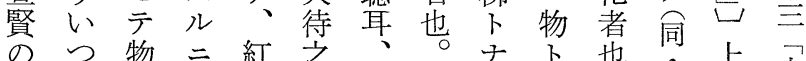

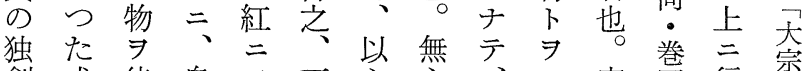

創式待自 $\ni$ 不心念、シ安四行師

我㠜凡落蘚

我凝合蘇 然

ワ 0 然坡

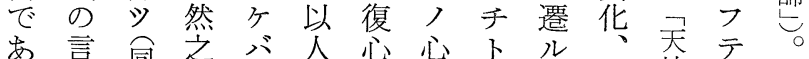

$\checkmark$ 嗒遺画 無

ゾ字其 竹 岕

我 取 身云 貌

るい同埋紅入全也モモ安地ュ

か季巻二ニ天若同りノ不㳊》

ぞわ分順ナ号然同レハ化者

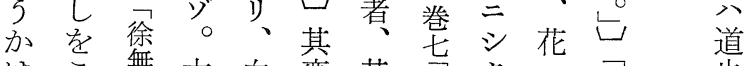

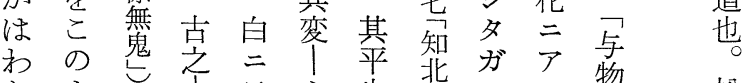

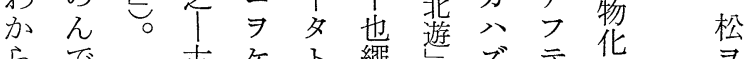

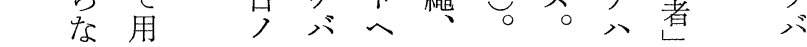

直五いの る 対よ禅禅に

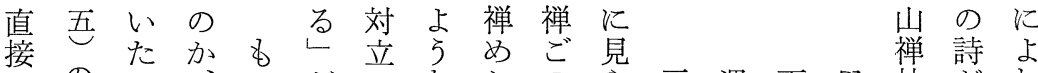

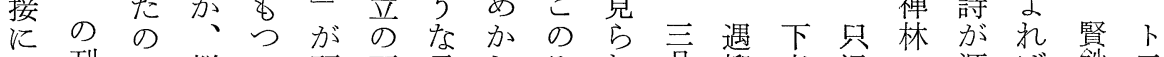

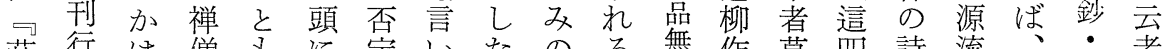

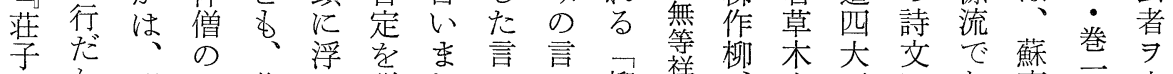

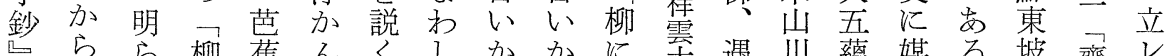

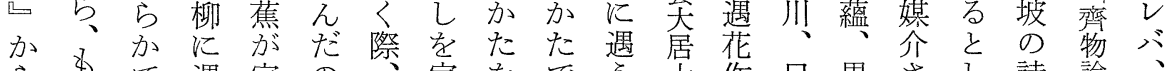

着 ち

想乃いての、坡がの何は周、森心たも、た

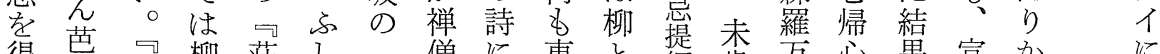

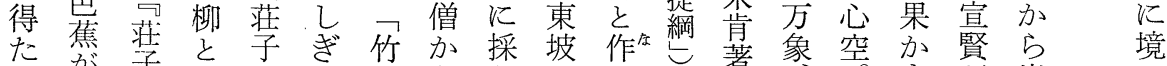

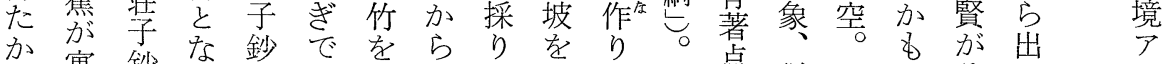

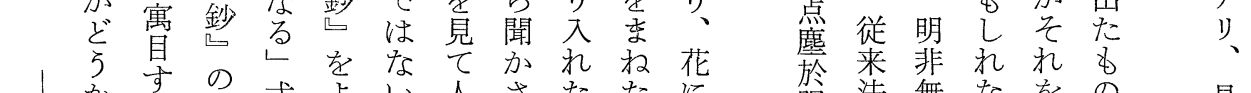

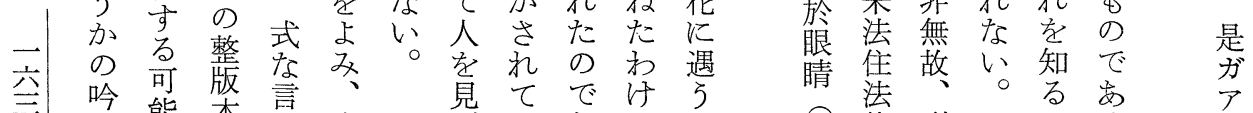

吟能本言、直、見でで

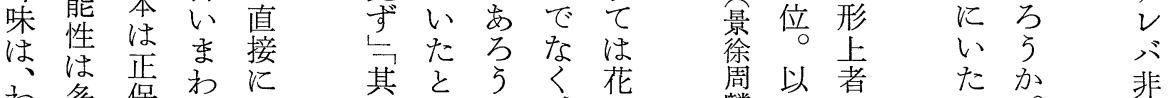

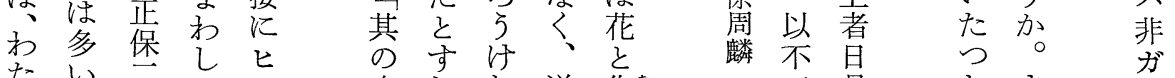

た

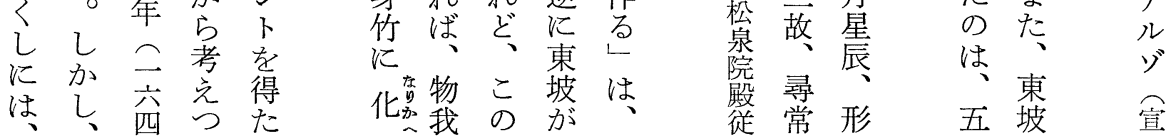




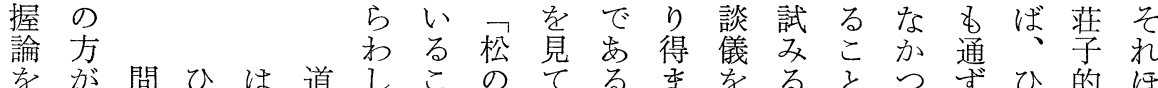
裏ずへたは道でこ

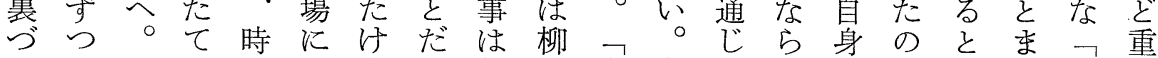
けと二なにてなけ松と虚もてて、代こず虚要

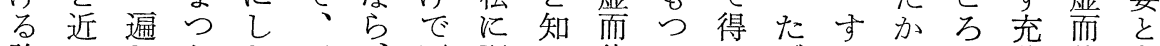
論いてりた 三、両習る待々たぶでらが分待す

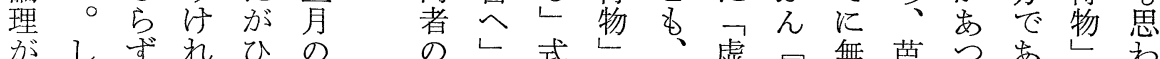
がしずれひ等がて

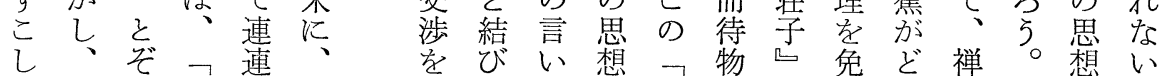

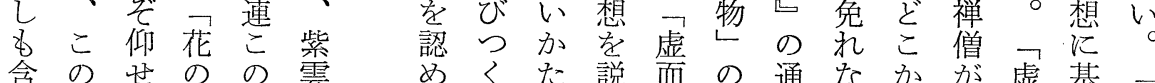

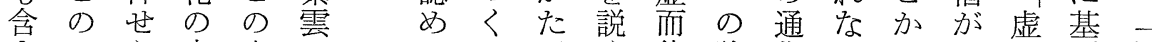

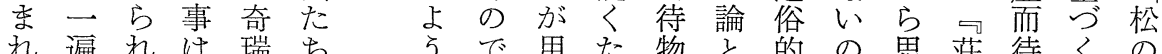

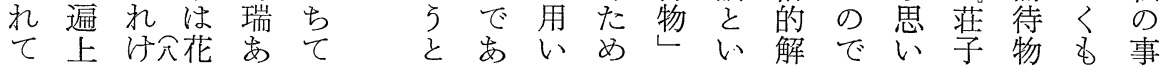

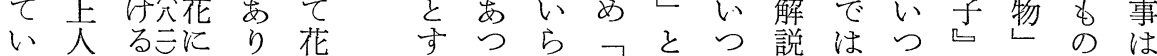
なの辛問きふるてれ花いた書ないるのて松

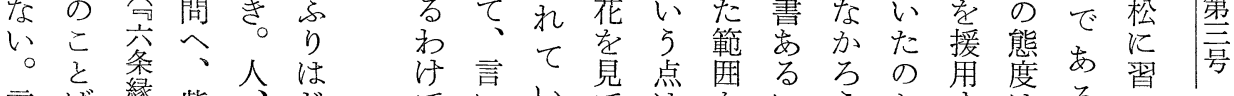

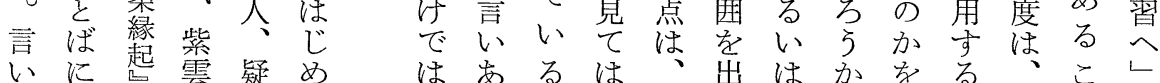
あは第のひ跨らか花たる禅、決こるとと

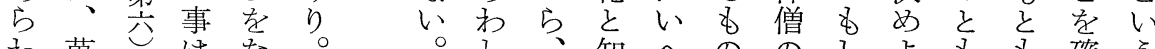

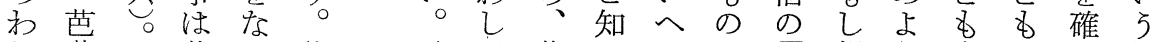

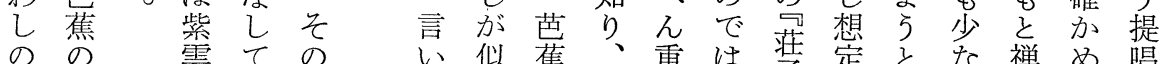

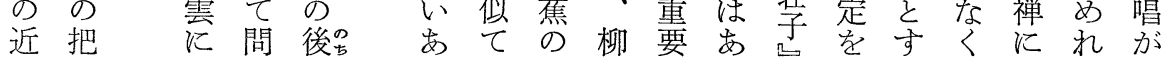

(b) (a) る 拈姿説を

天行結申ずこすするす検り 亭

地のびす我のな 考赤討ぞ期

固俳かこが道わ市をこに

有諧衫々思は占か子通乃物

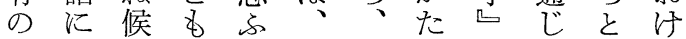

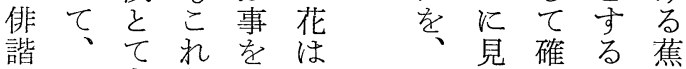

あ思本無一待呂究方手風

りひ、句了

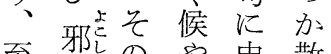

るな心

ベきづ花述か

ᄂ。多学仝

楽な⿱ る 委は

乙りそ!量

ざの鳥の学

乙 ち、聞諧 晴

花こ经学

啼李を他方

塋皇二習河

- 地句ひょ
丸るめの号

の \& 5 で 形

用の机盛

聞でるらが

書离。

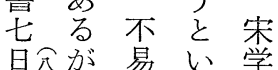

草三、流 5 亿

吅行气裏

にの説と方

上子尔はけ

D 5 小 5 て ひ点さ れ 知とばらた

るつ湔萗

之 成不的

が段さ易世

で階れ流界

き決行観

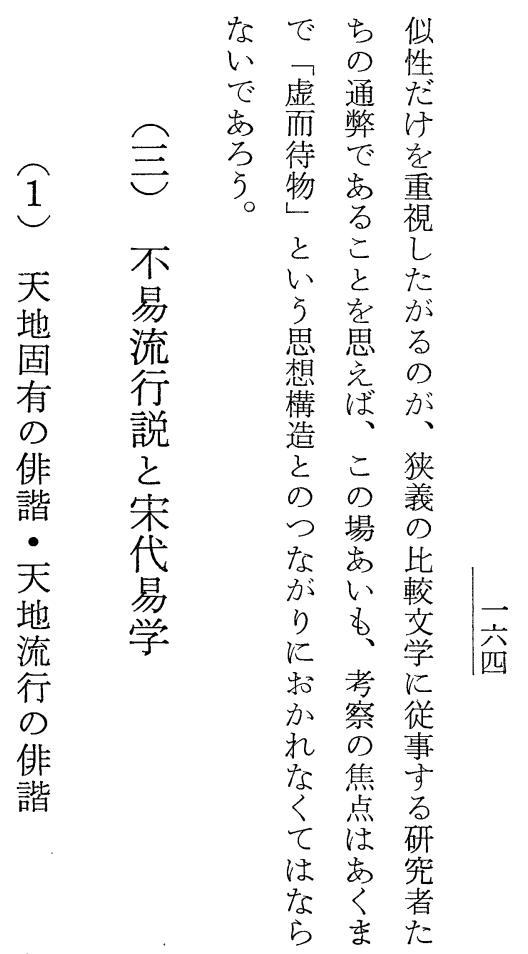




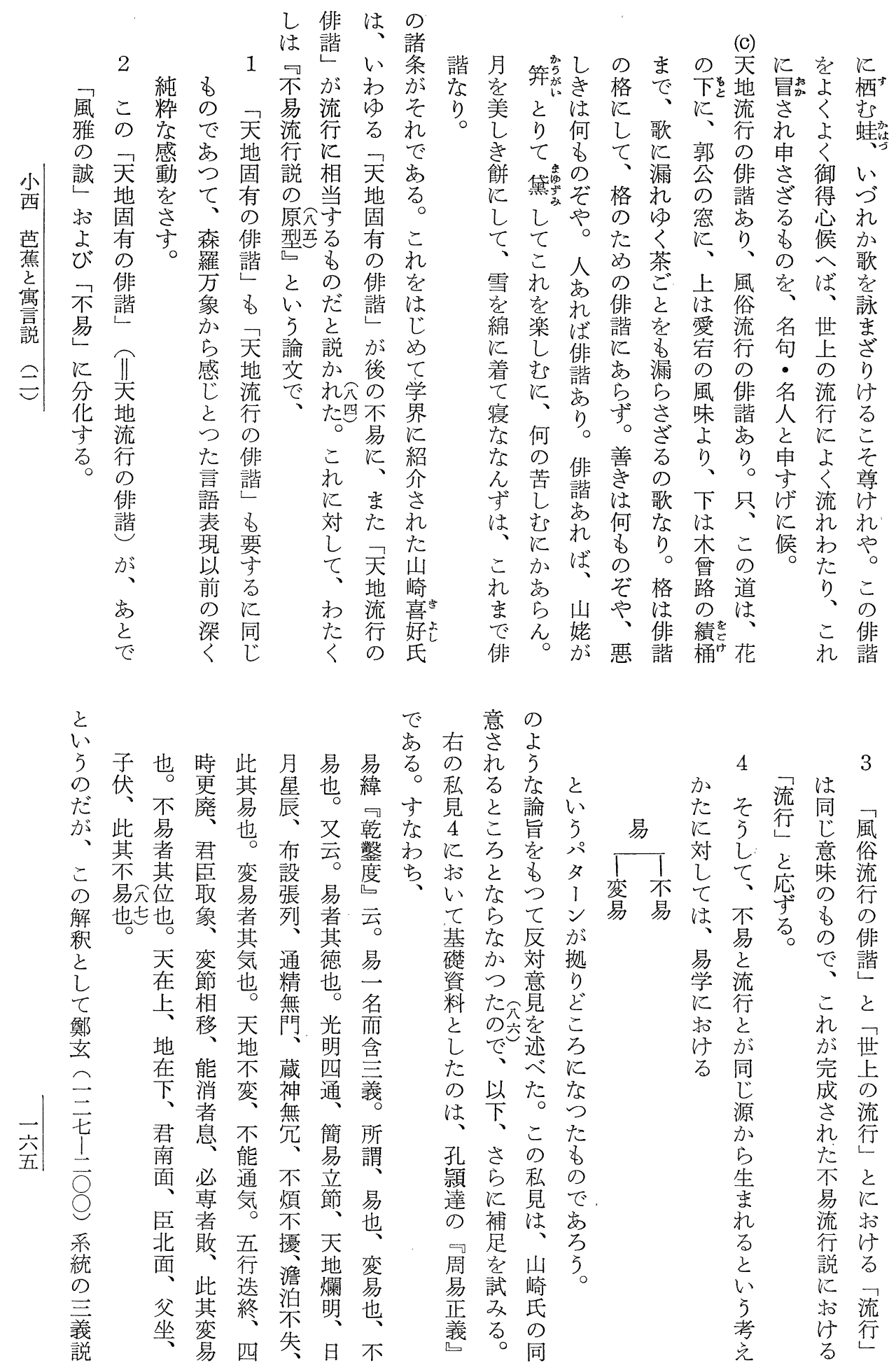


く形け行実易不はの恵ては岕け行て抒

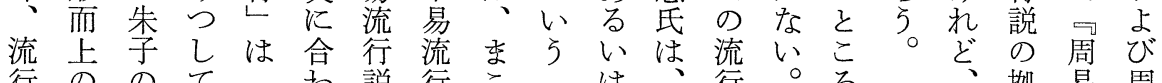
行ののて、わ説行こ、は、行。ろ

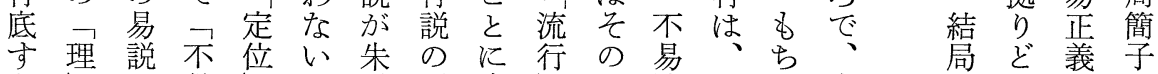

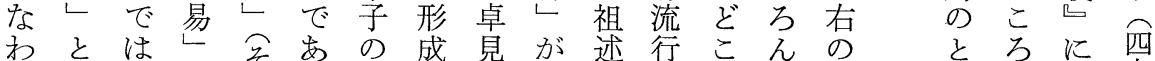

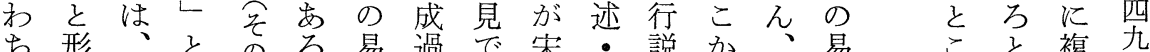

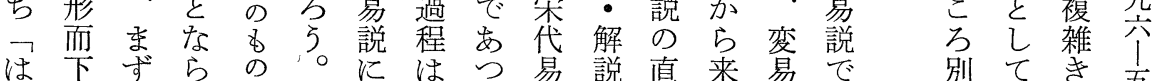

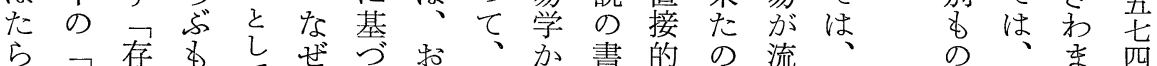
き気在の識かいそ宋ら富なで行不で単る のに令で别々 て

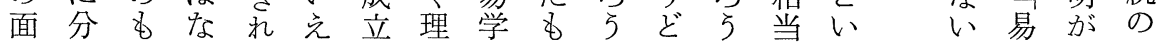

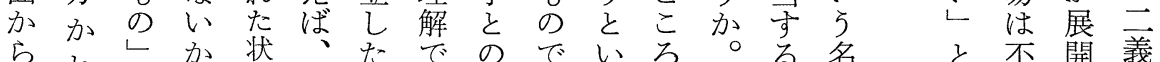

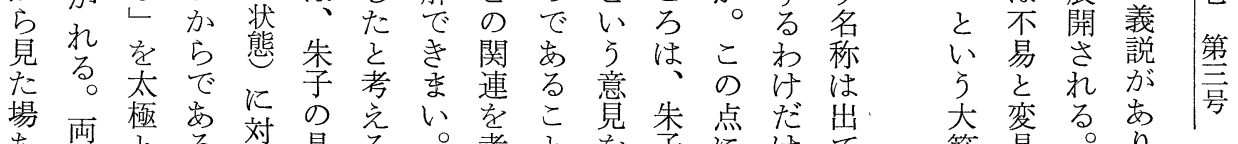

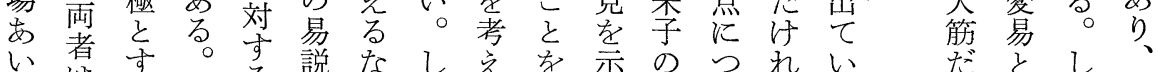

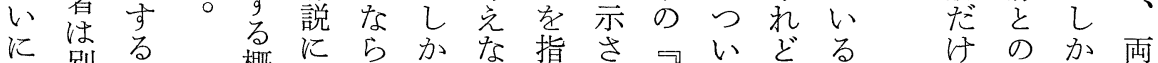

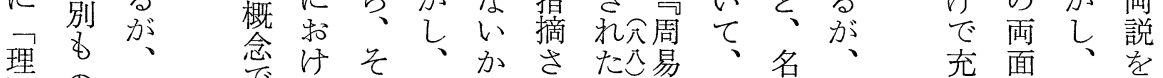

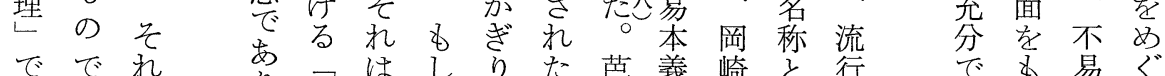

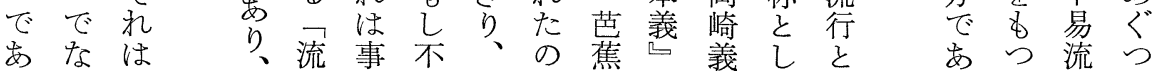

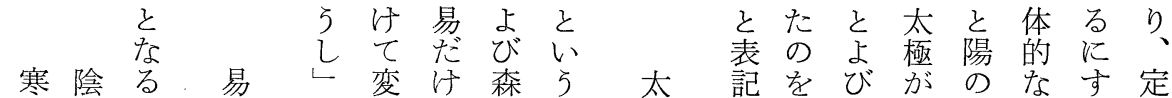

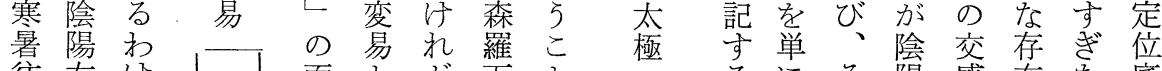

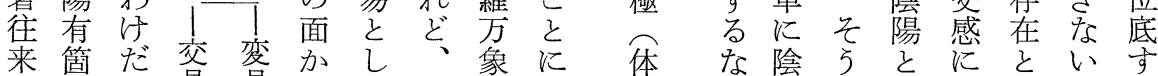

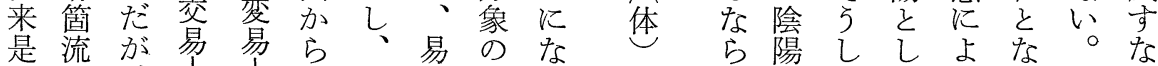

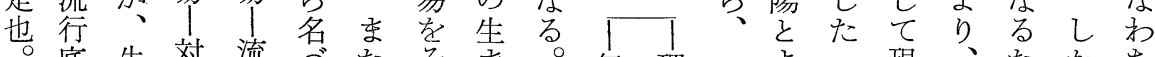

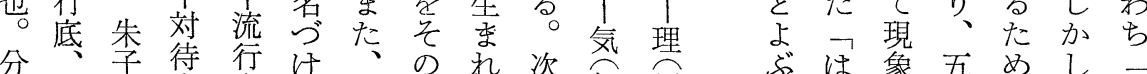

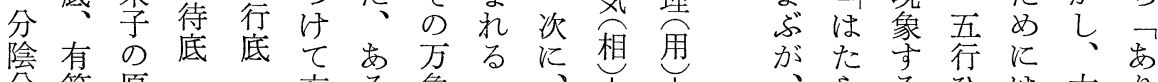
分筒 原

陽定交

義底

昰一次

動 の

便是静和

定 互

位為述

底基 ベ

天杝便光

地是

卡流る

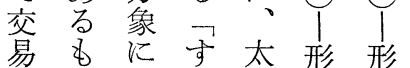

、らる ひ は 太 り いきフい、極さ

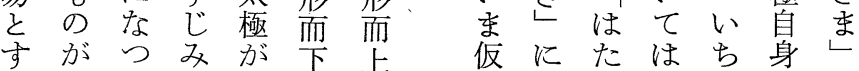
る他て占陰下卡陰ら森打はの ○のゆ上定流前之き羅 5 具面 す $8<$ 陽位行者陽方陰体か

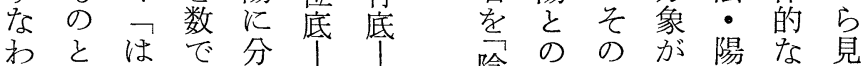

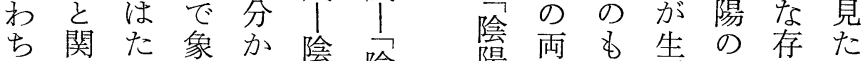

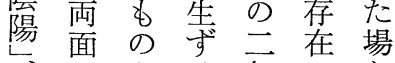

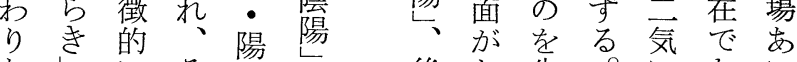

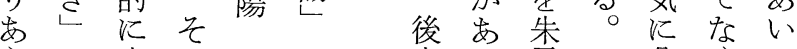
弓 $の$ 表 こ 颃面現少 互 5 る 五 者る子こ分くに を観場れ品気 陰権察陰掦る杂気

陽吉陽陰具

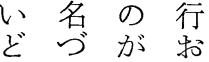




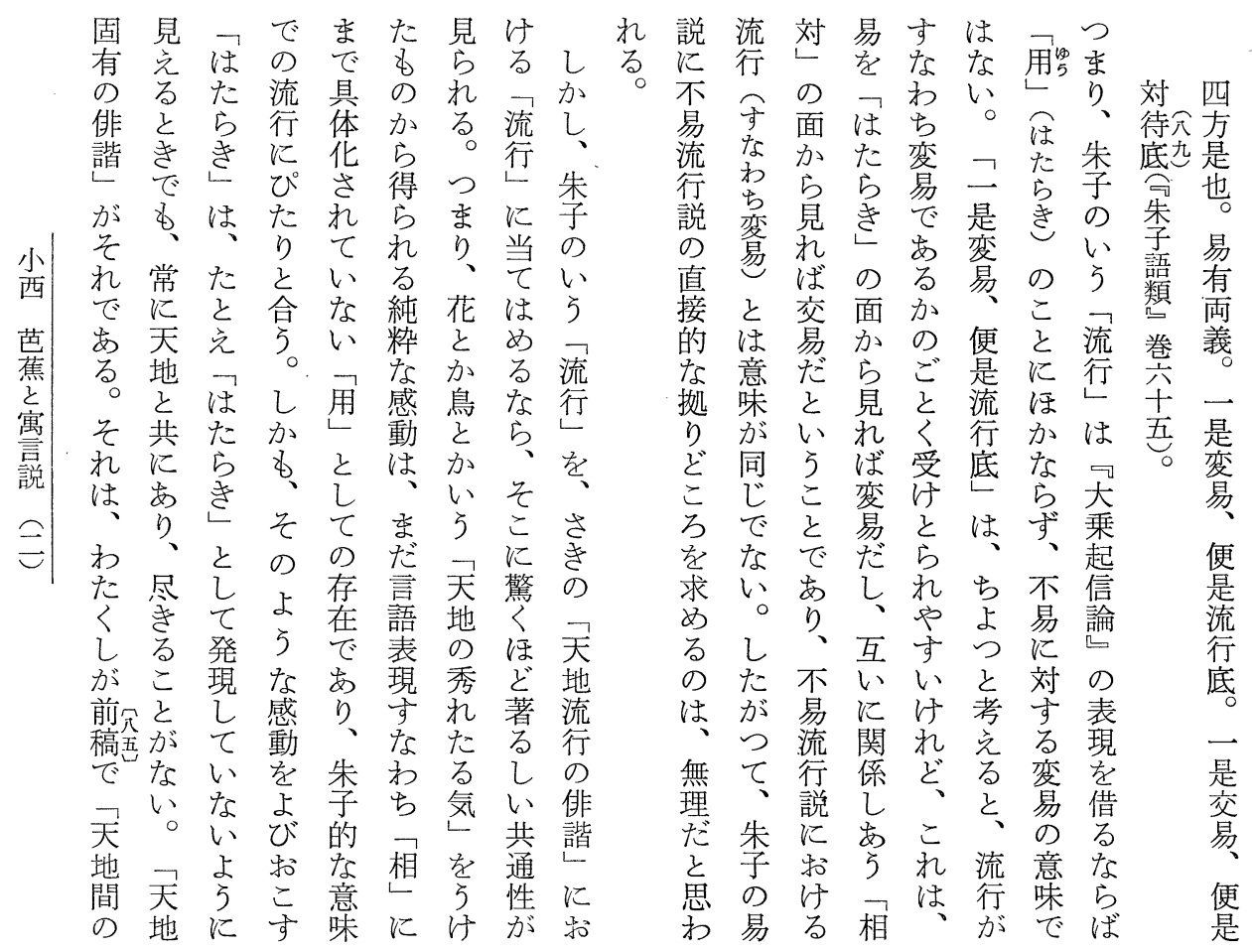

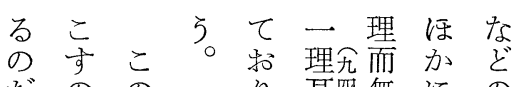

だの方り耷西無に市

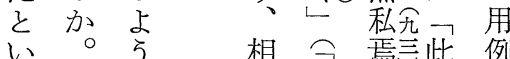

万朱な 相与烏些例

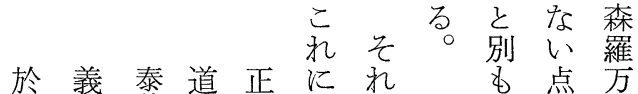

物理伯理理つでの孞象

の宙

論 に

乙趙 詠在答則暴

で 充

は、塞

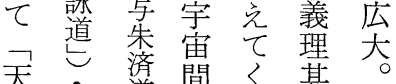

そる 有理塞此有あ 嘗義

天气済間く

固此 - 未る有无惟

は理

俳塞 此有 女

宇埋

宙は

俳晏理所

辛

々 誰巷道 陸齊

身 ぞ W能宙㤁象

意乞

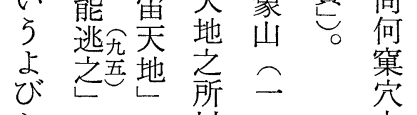

䓌

なは

わた

桌占

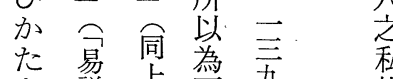

命き

理竟説至杂

衹を

薢な゙塞者卆

上抒

せ述宙順は

苟
不
蔽

無在いて
奇特心は

は心内

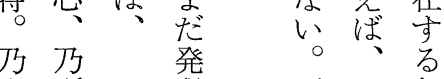

㭆所 登 両ま無

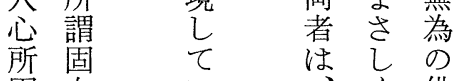

固有少俳

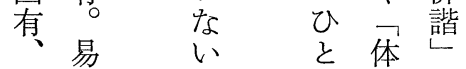

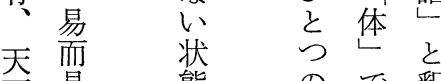

下易態 ので釈

所知学事はし

共簡な゙ のあた

由而苦表る

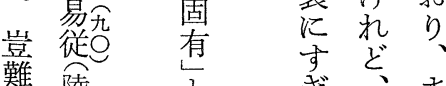

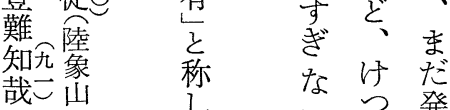

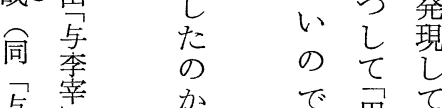

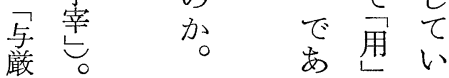




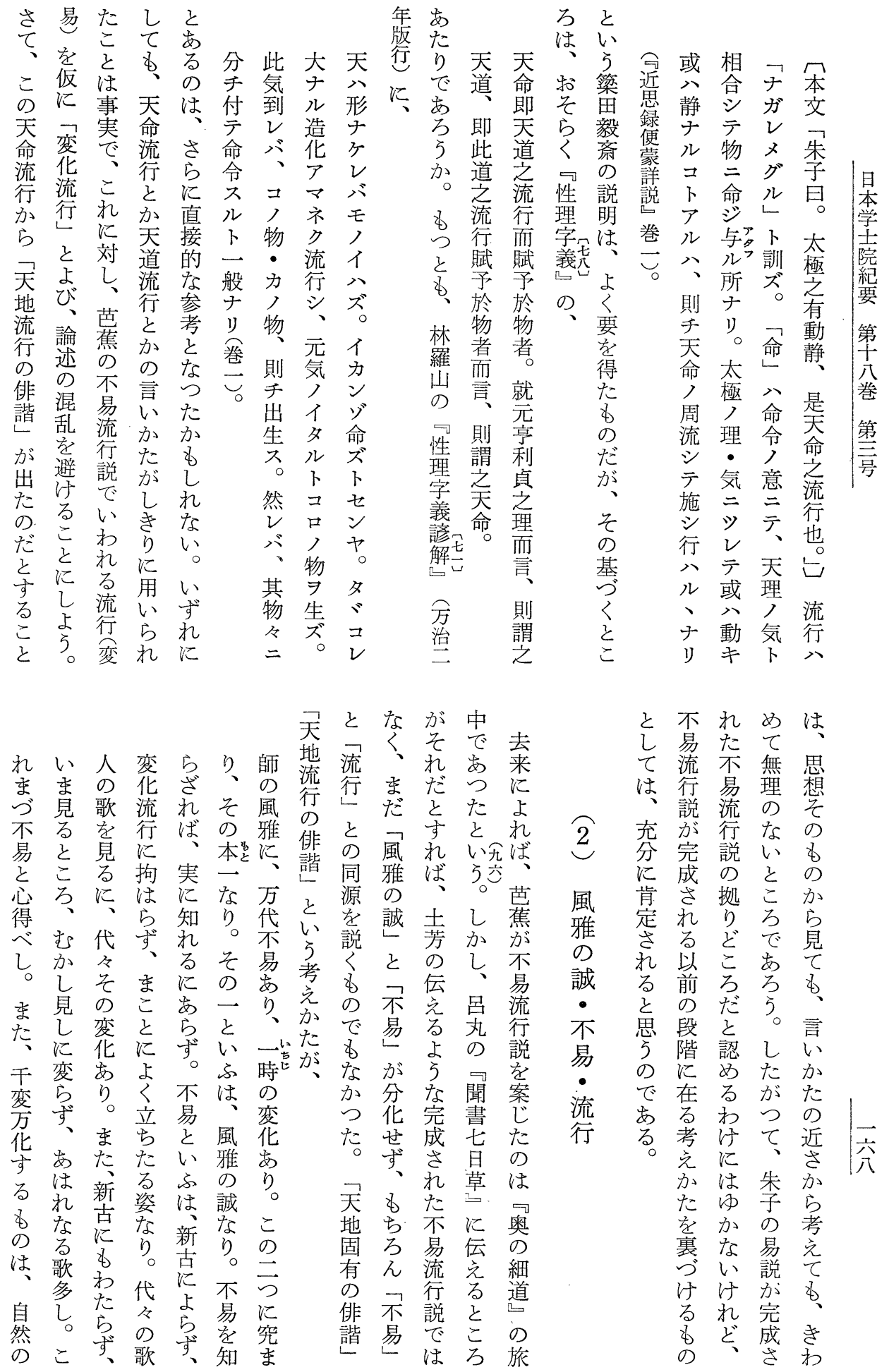




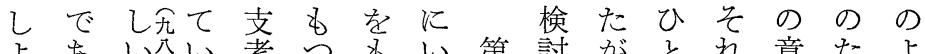

ま

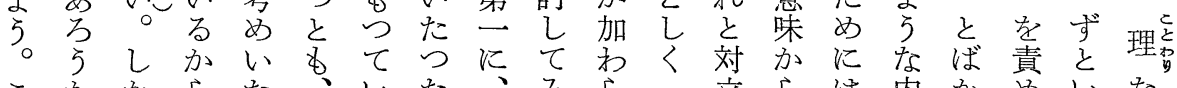

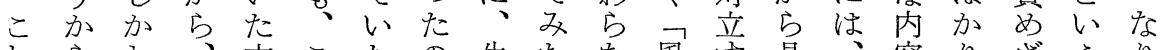

れらし、齐こたの朱たな風す其、容りざ怘り

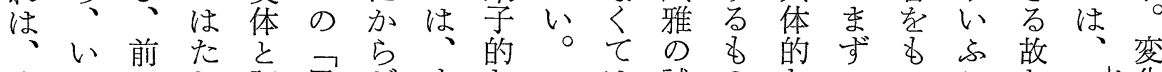

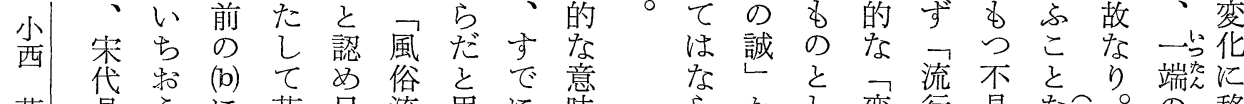

芚易 5 に芭呂流思に味

蕉学芭出蕉热行方芯

ならて踢行易しも責流

寓の蕉て自の年聞の

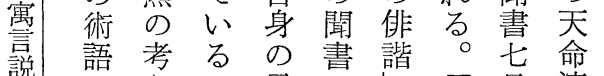

説㖣克っ言意誯風早流

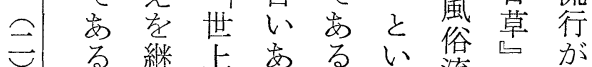

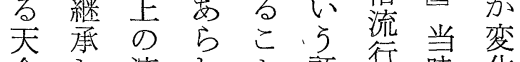

命乙流方々語行寻花

流た行し学は俳考行

い生の范行沗め行ざ

で李 不朱説䞑ず记

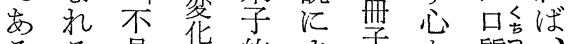

万易流的弯車凝質風

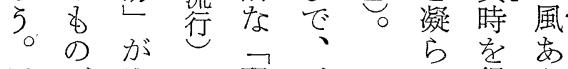

以だ登を現ど㐫得ら

下之場さ象ら莳たた

、いて卞导し尚る

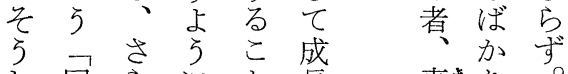

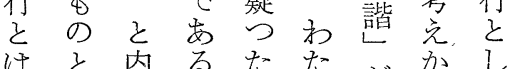

違認容か 六)たがかて

違認容が (c) そ究だて

、るにう部が杂文握

普こはか分前分での等

通之同疑飞稿吾交萌就

乙同方飞を長

た源にかしで具に是

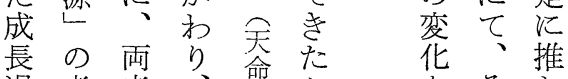

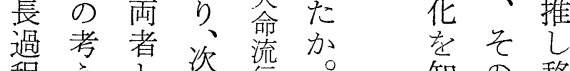

程之次行。知の移

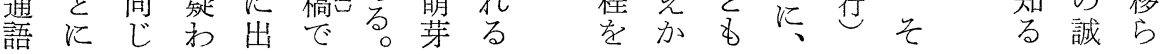

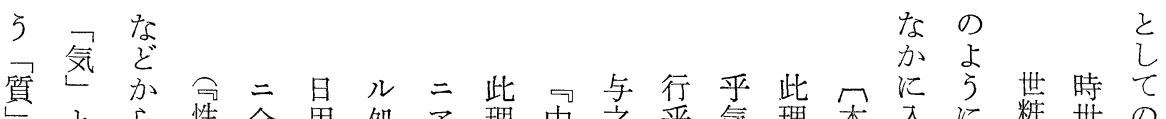

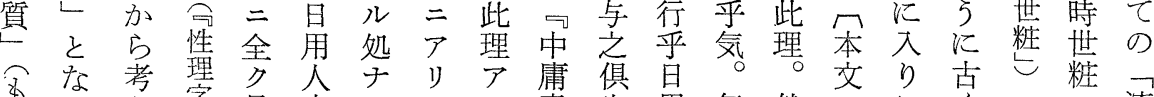

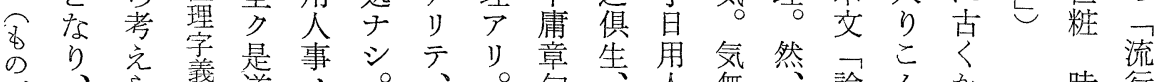

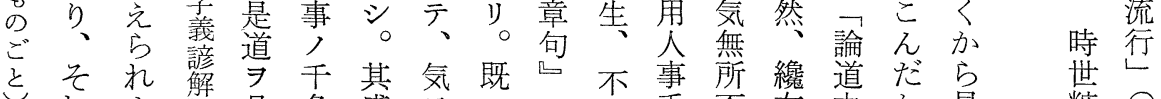

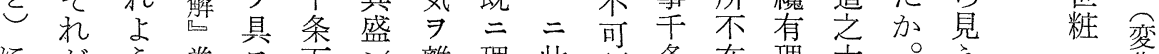

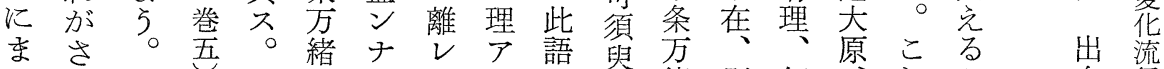

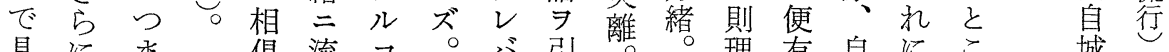

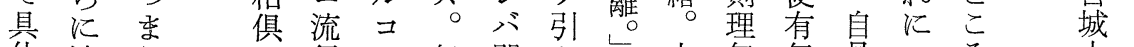

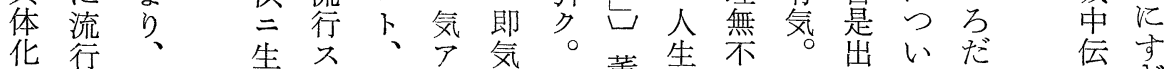

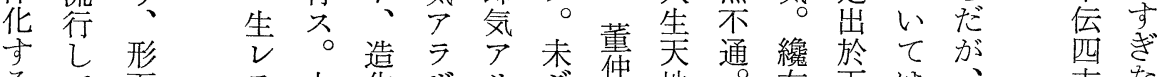

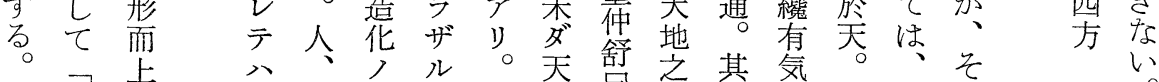

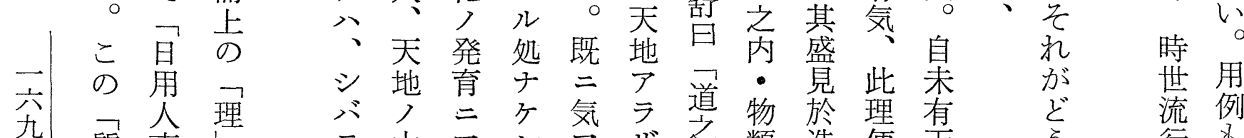

幦事芯 ラ 中 ア

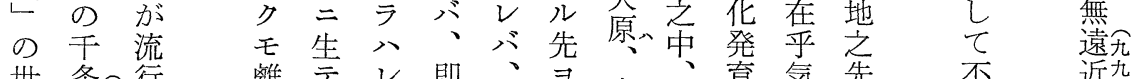

世界务行 離示

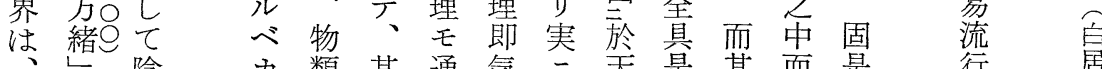

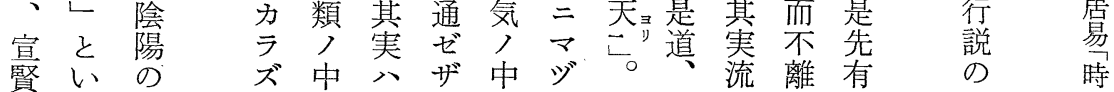


にら学々流がるなとと名易を

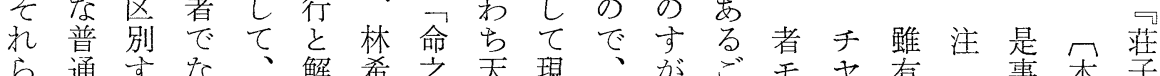

の語るい变し逸行命象そたと其ツ知規、事交鈔

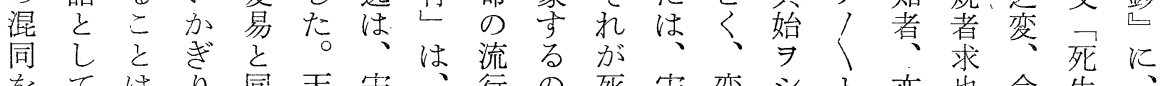

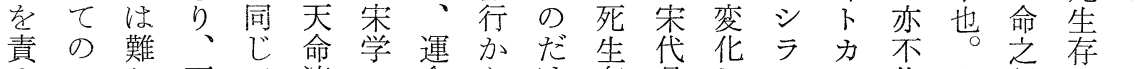

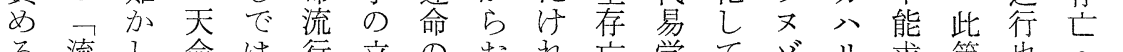

わ流々命

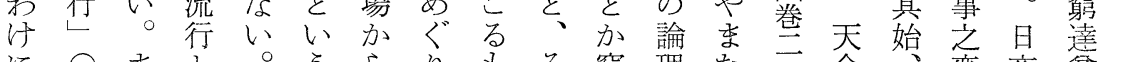

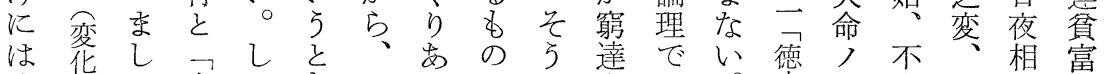

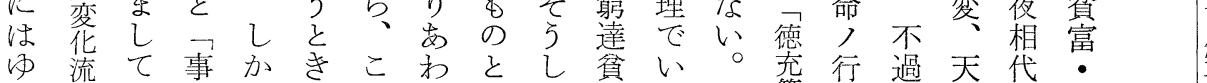

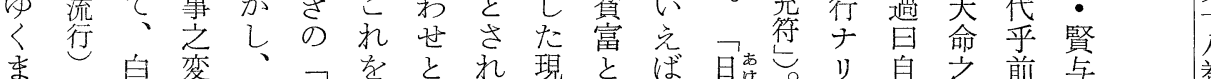

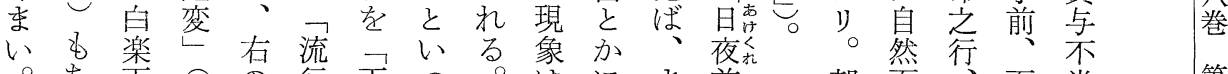

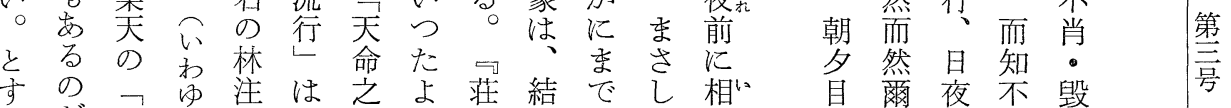

れだ時る市は往点蒋結でし相具く貝雨夜不毁

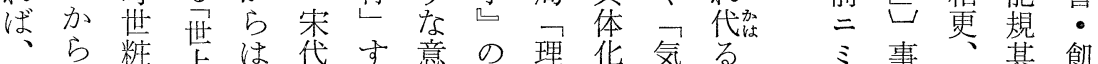

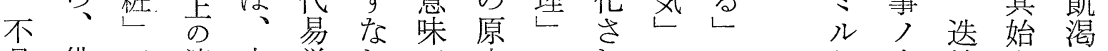

易俳で流本学わで交のれ飞と処変於者。

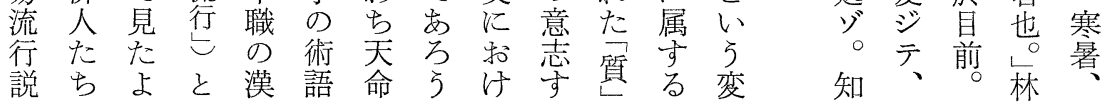

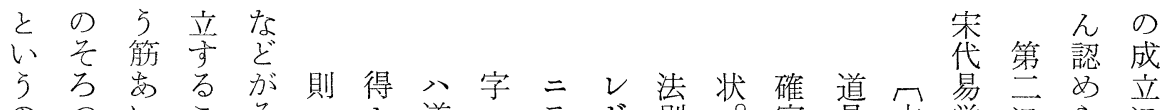

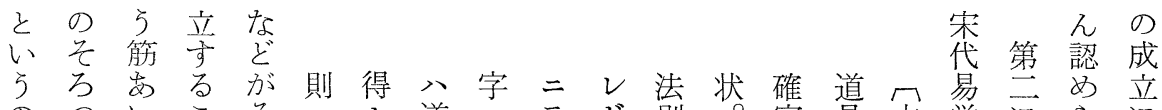

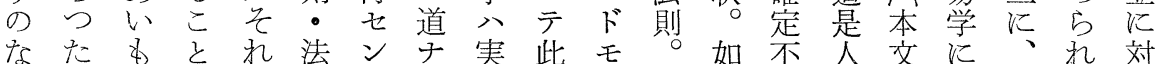

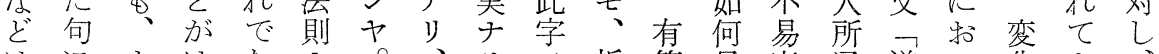

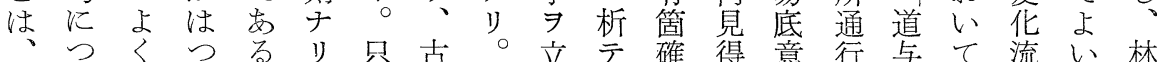

右い示き表只克力立テ確得意行与て流い林

のてさりし此事力多。字否只故上基不々です

例子机杂確事ワク理下易是章大易対な荘

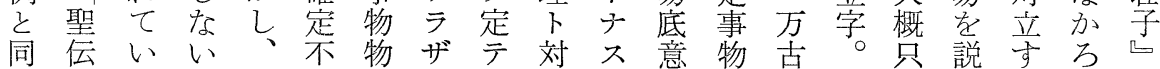

じのなしこ易ノルカカシ゚方上通与是くるらが

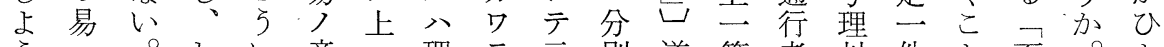

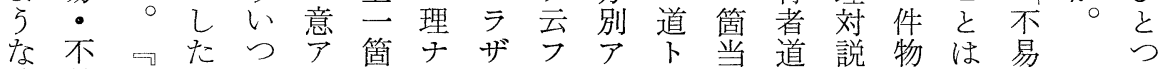

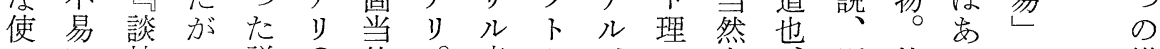

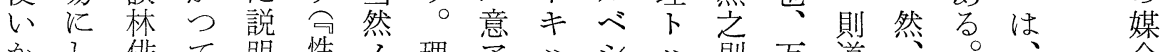

か乙俳て 明性然理意 、シ 、則万道析。

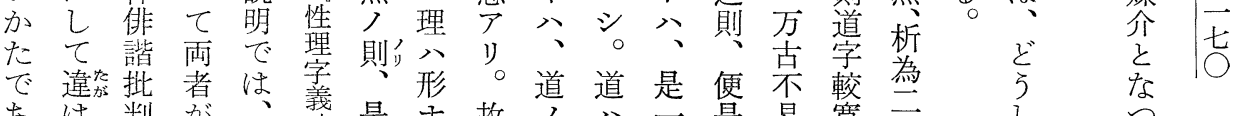

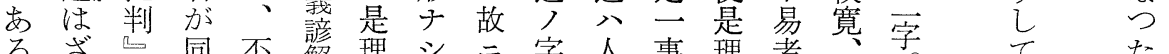

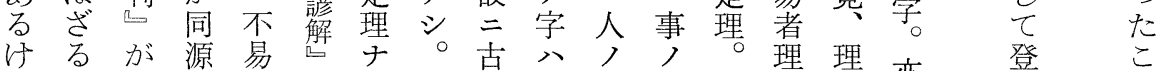

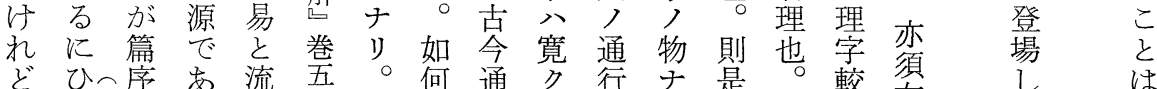

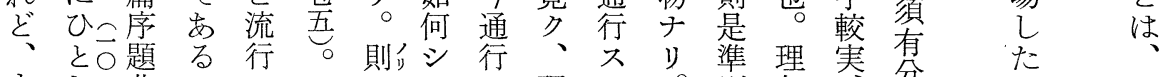

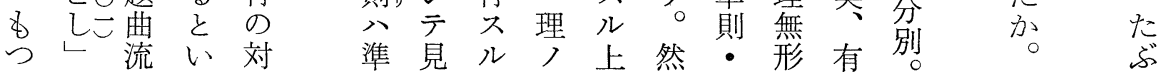




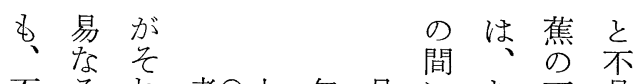

テシナリ便行古也口不る机者之無易に步不易

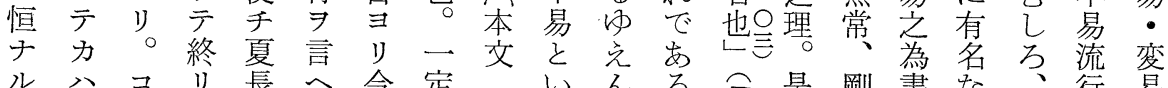
ルハコリ、長へ今定令いんる合是剛書な、行易

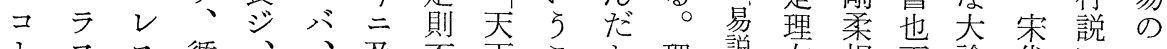

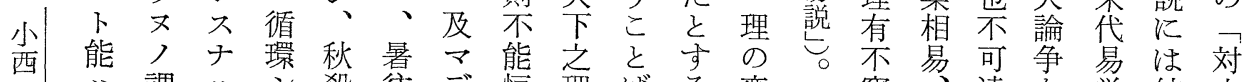

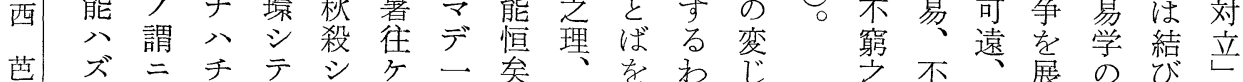

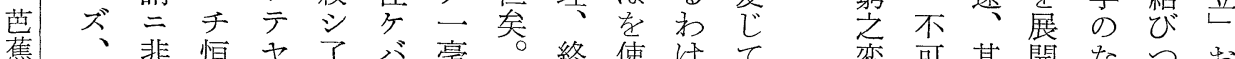

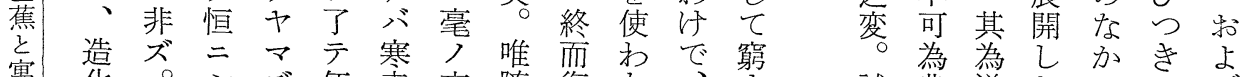

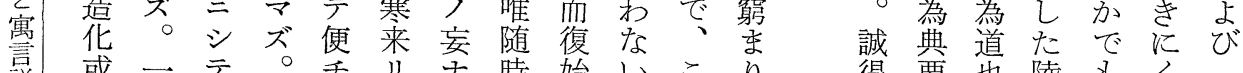

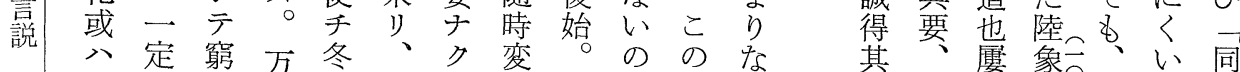

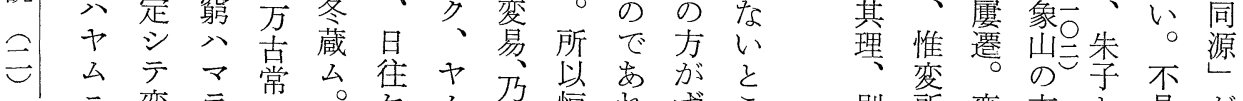
二变 チ易ザ如元バコ常而ばつろ変適動に違即离

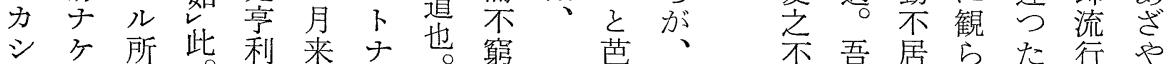

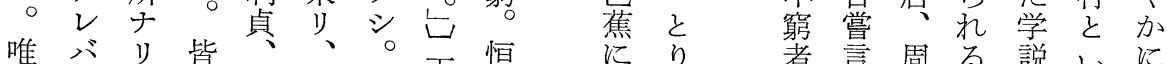

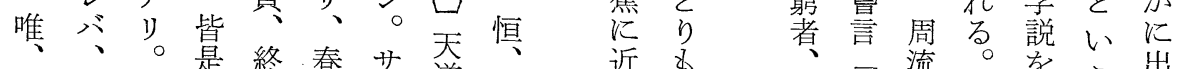
其り恒真終春节道非近をな

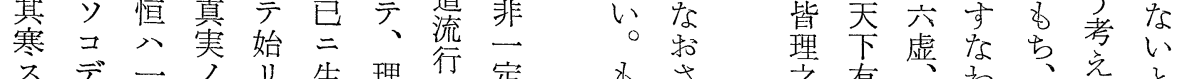

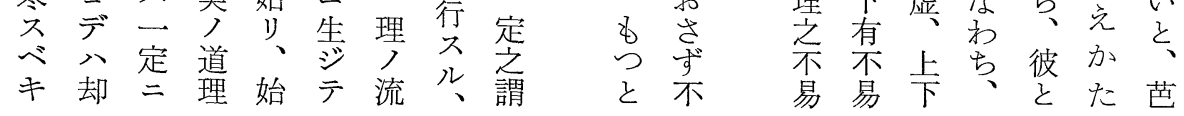

$$
\text { た棸っこ源ざ導な }
$$

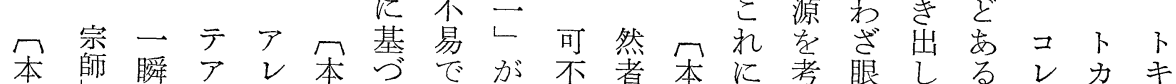

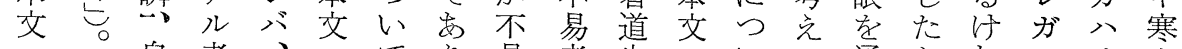

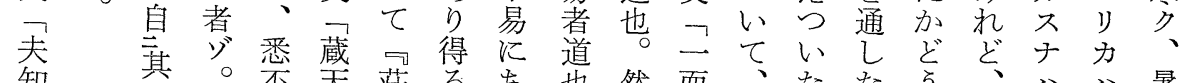
知基。不薄る荘也然而、たた

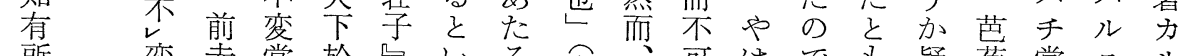

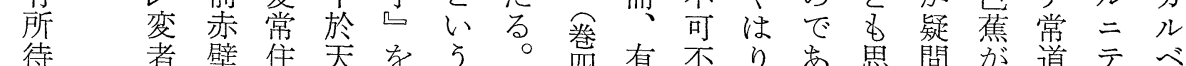

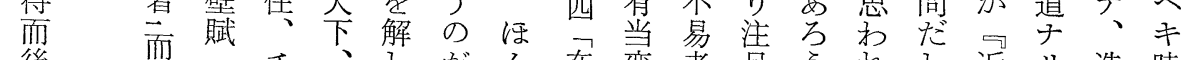

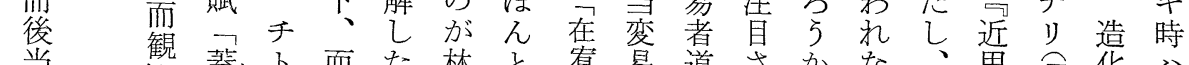
当觀蓋卜而た林々有易道さかな

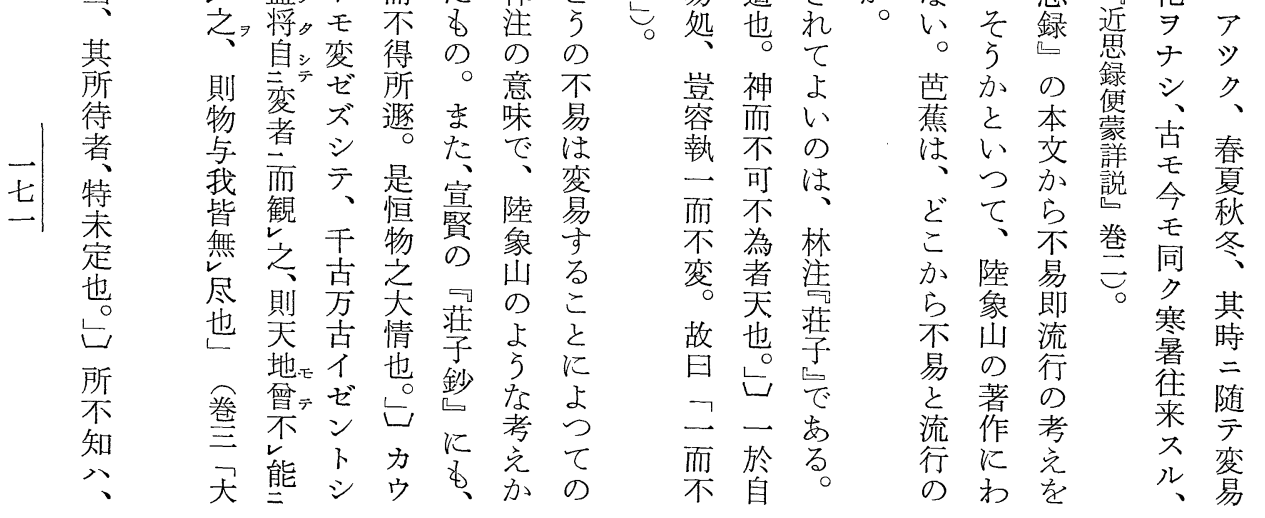




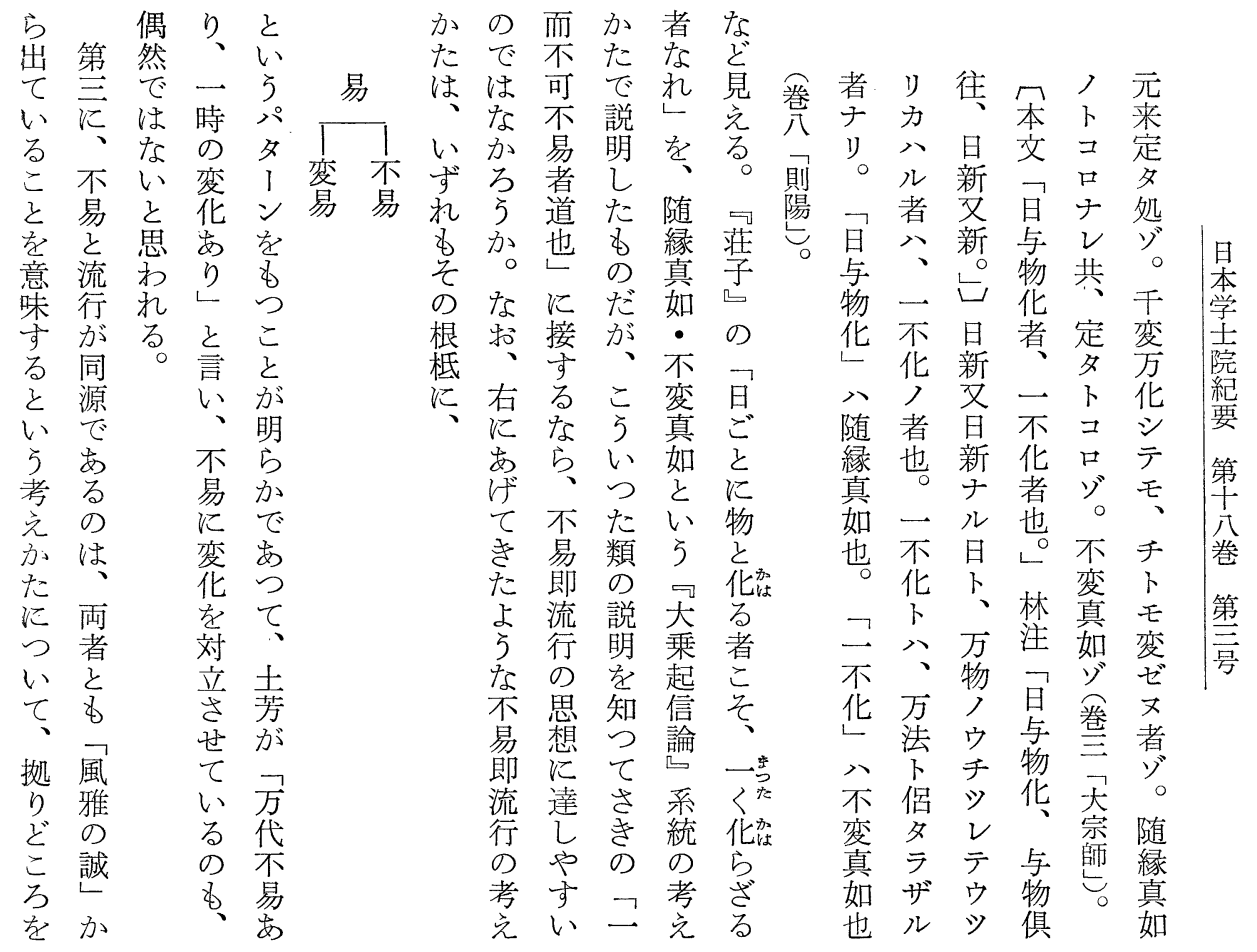

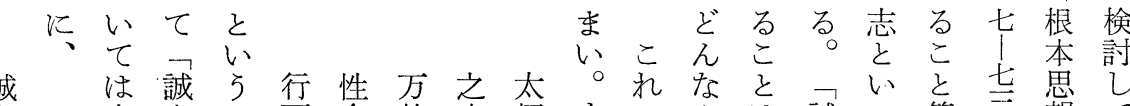

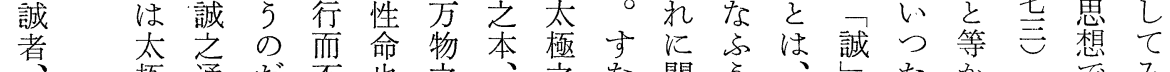

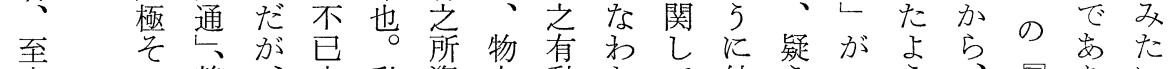

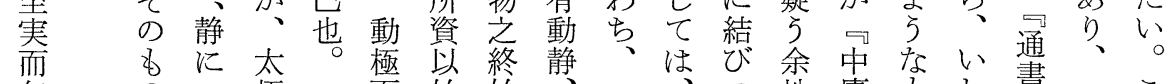

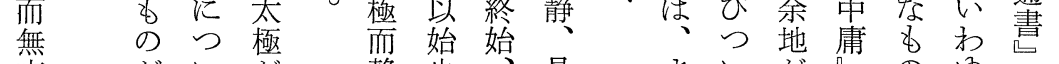

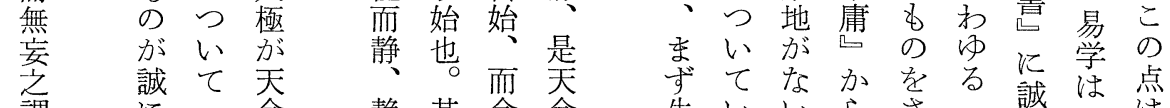

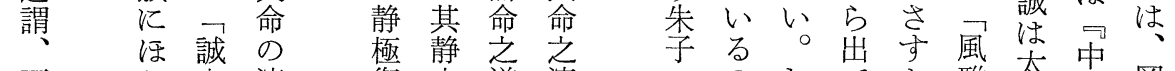

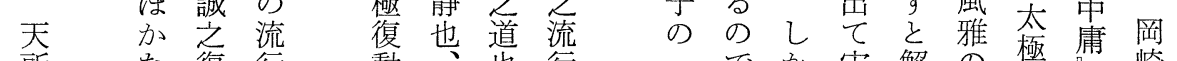

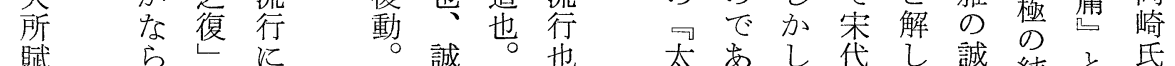

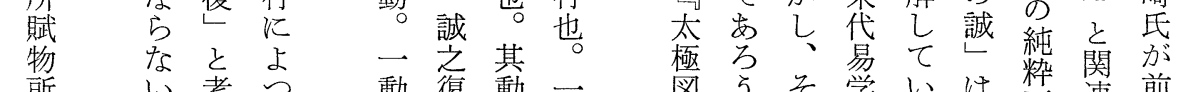

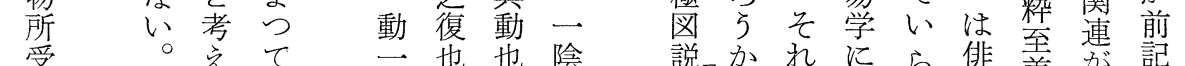

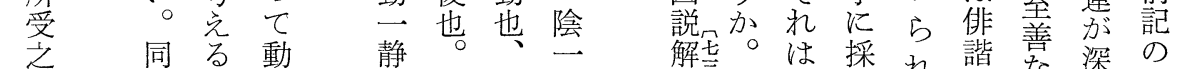

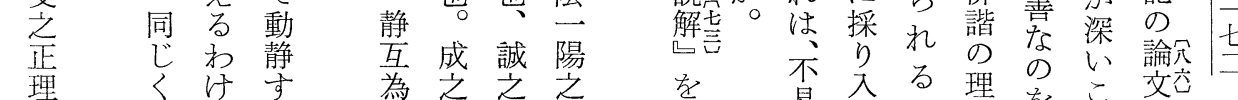

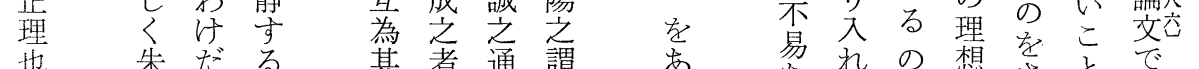

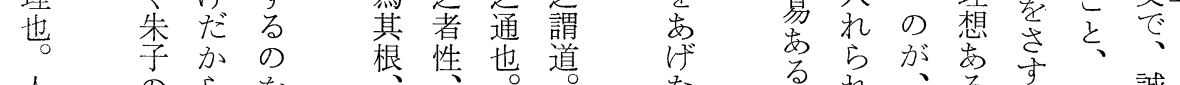

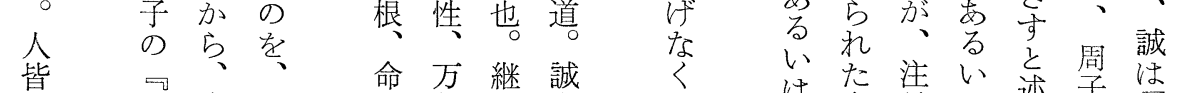

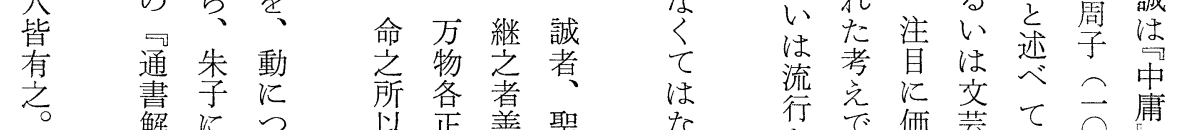

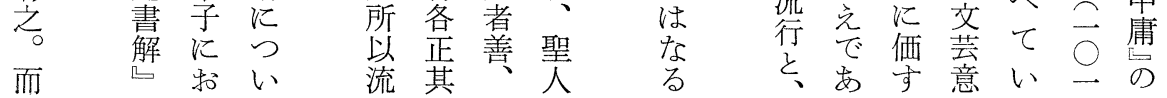




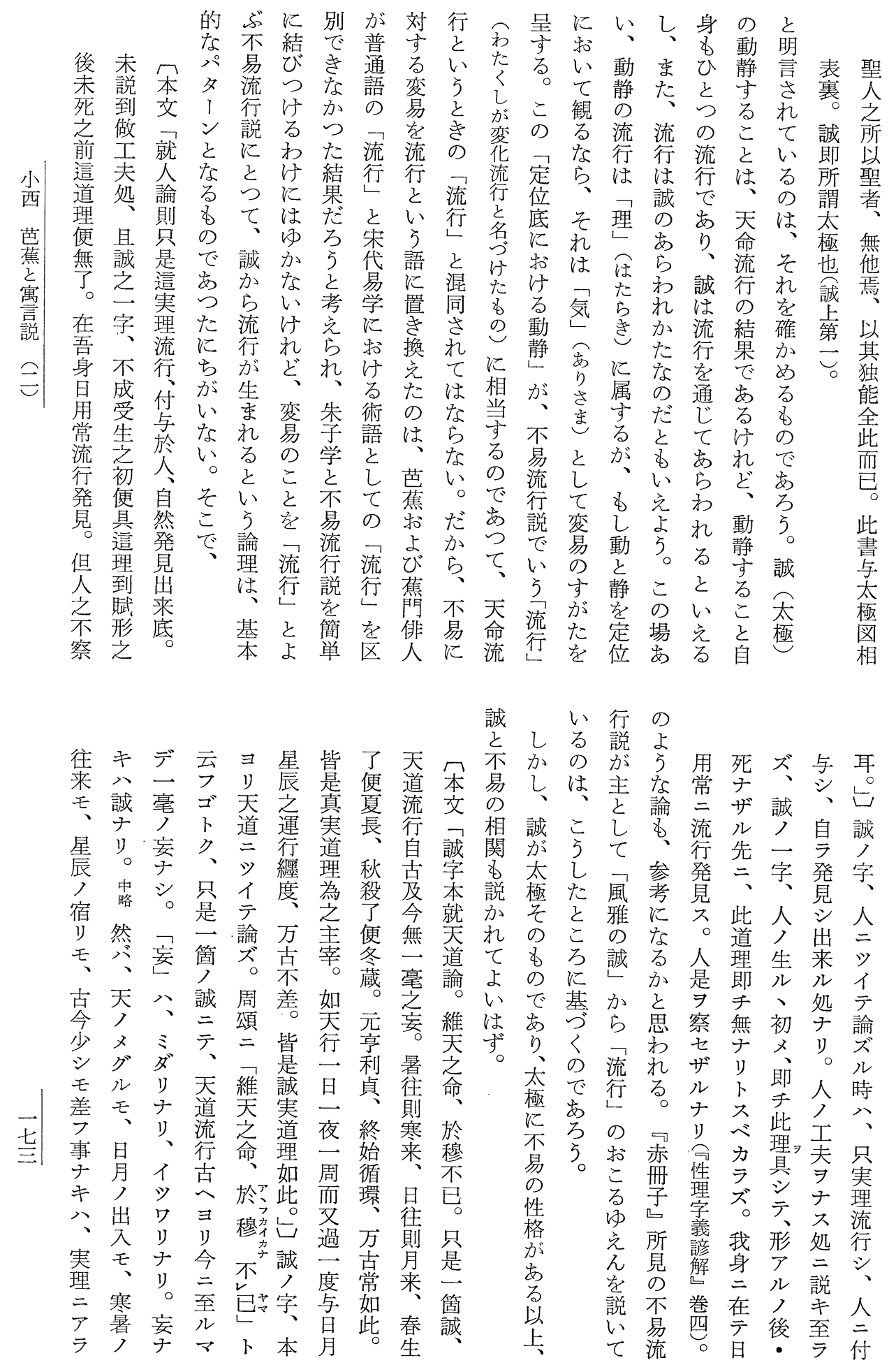




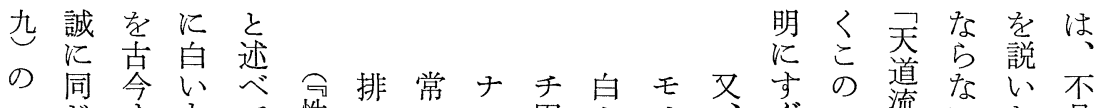

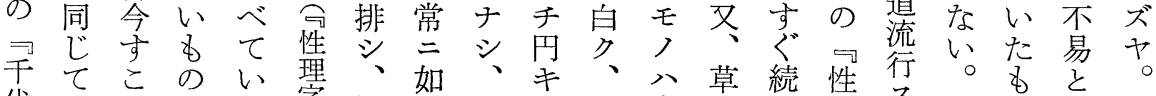

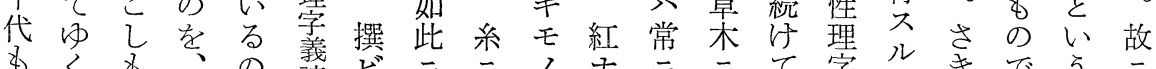

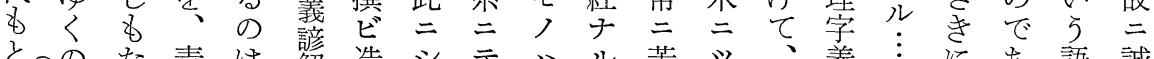

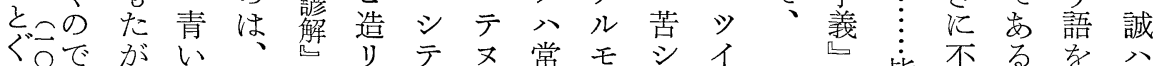

さ四なはとた卷来、フコ一の皆易。角天

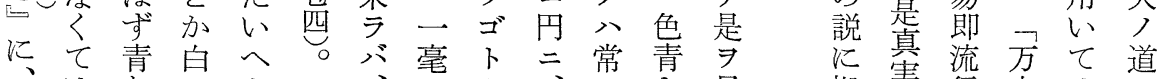

は山い几、岁り、き見拠寒行古はな

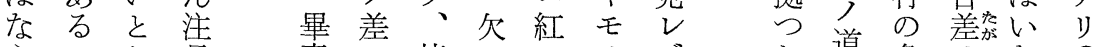

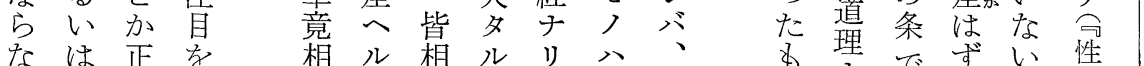

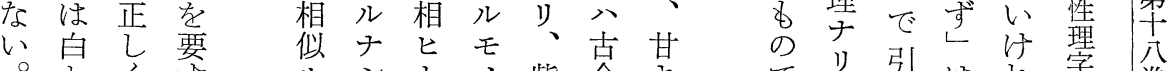

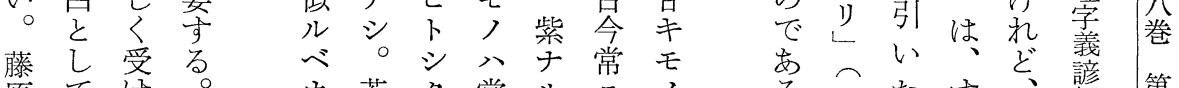

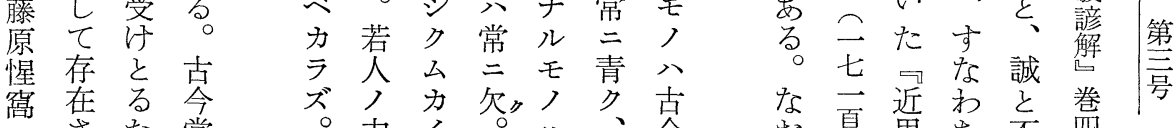

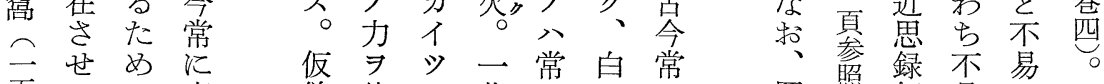

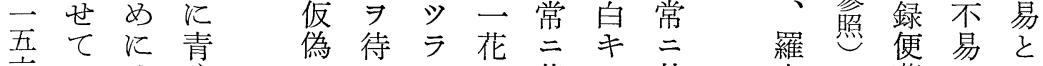

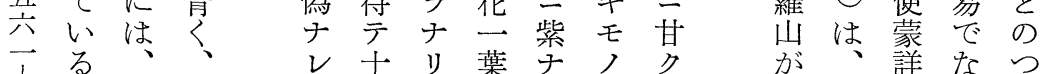

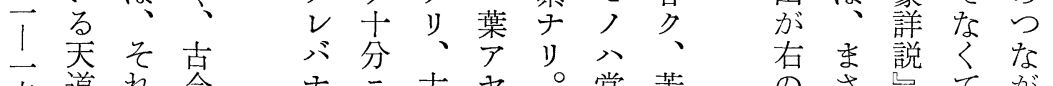

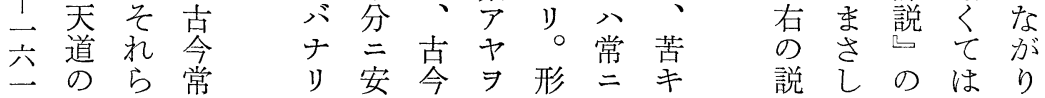

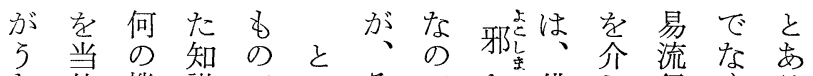

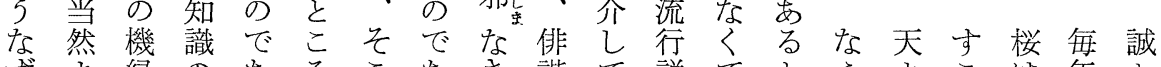

ず志縁 の

るこな給 5 ら理ひ別も毛偽

でとく源芭芭生誠聞想々造ら頭な

あに漫に。蕉をを書なら化な偽くし。を资き

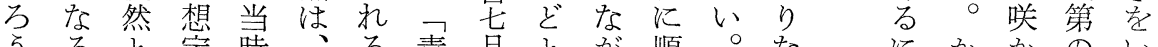

5 る と定時、る責䓥とが順。な的かかい

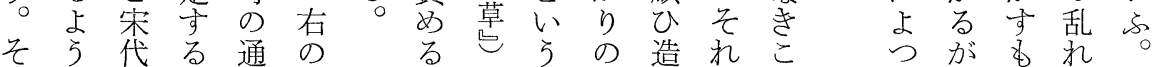

こ易こ俗よ境観思化が华てゆ誠ぬこ

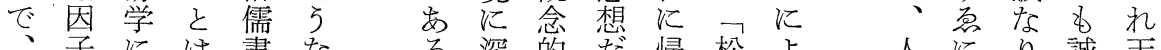

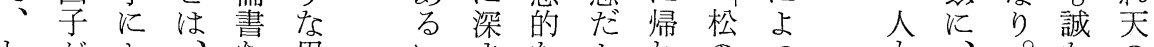

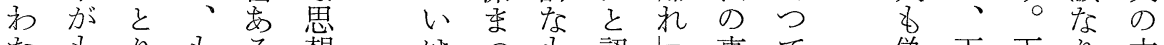

たもりるる想はる必認七事て 偽天天引本

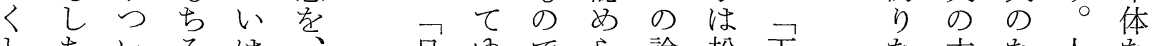

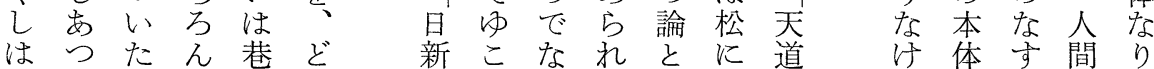

はったた

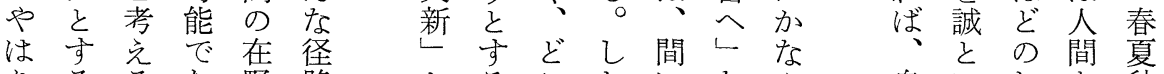

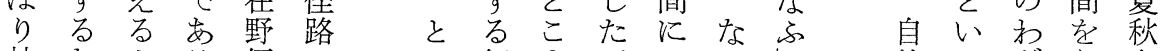

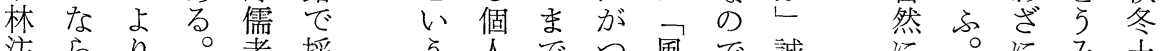

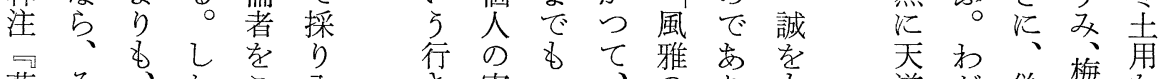

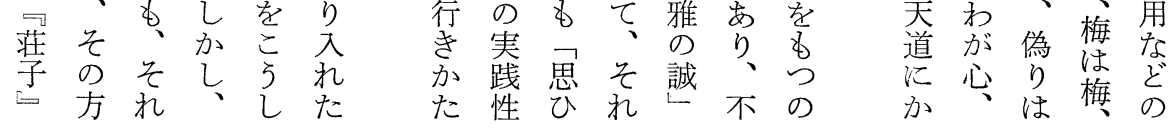



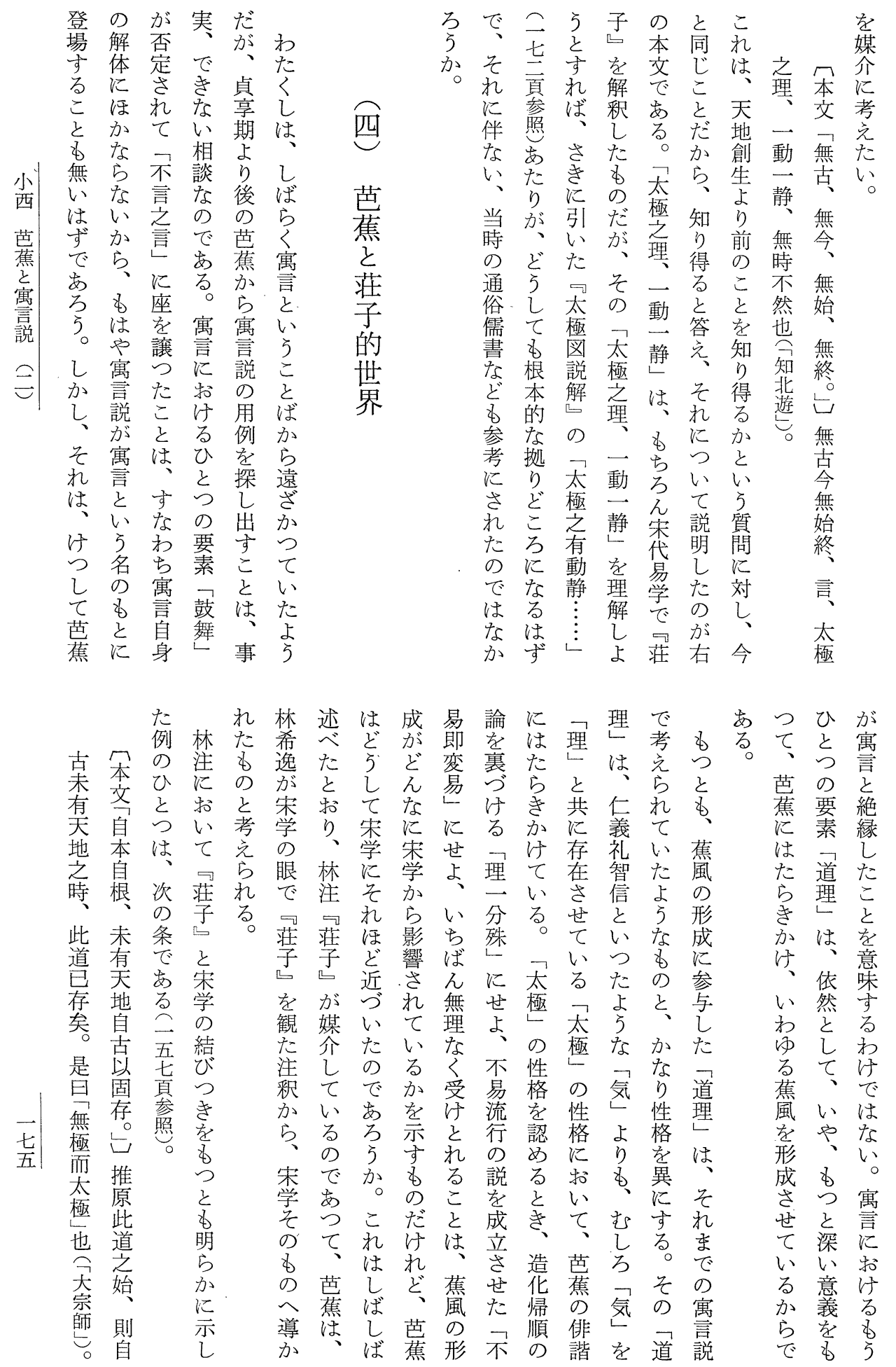


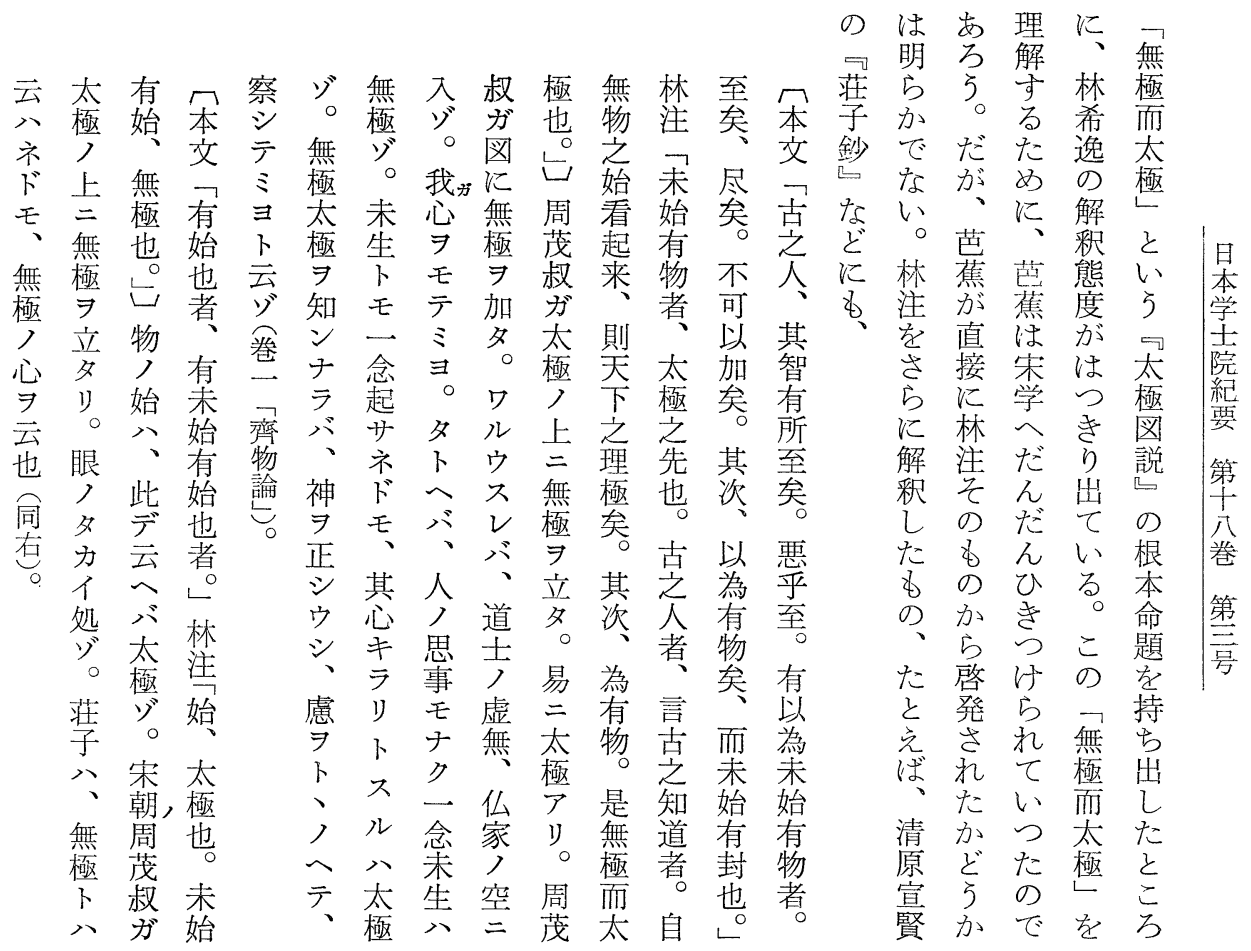

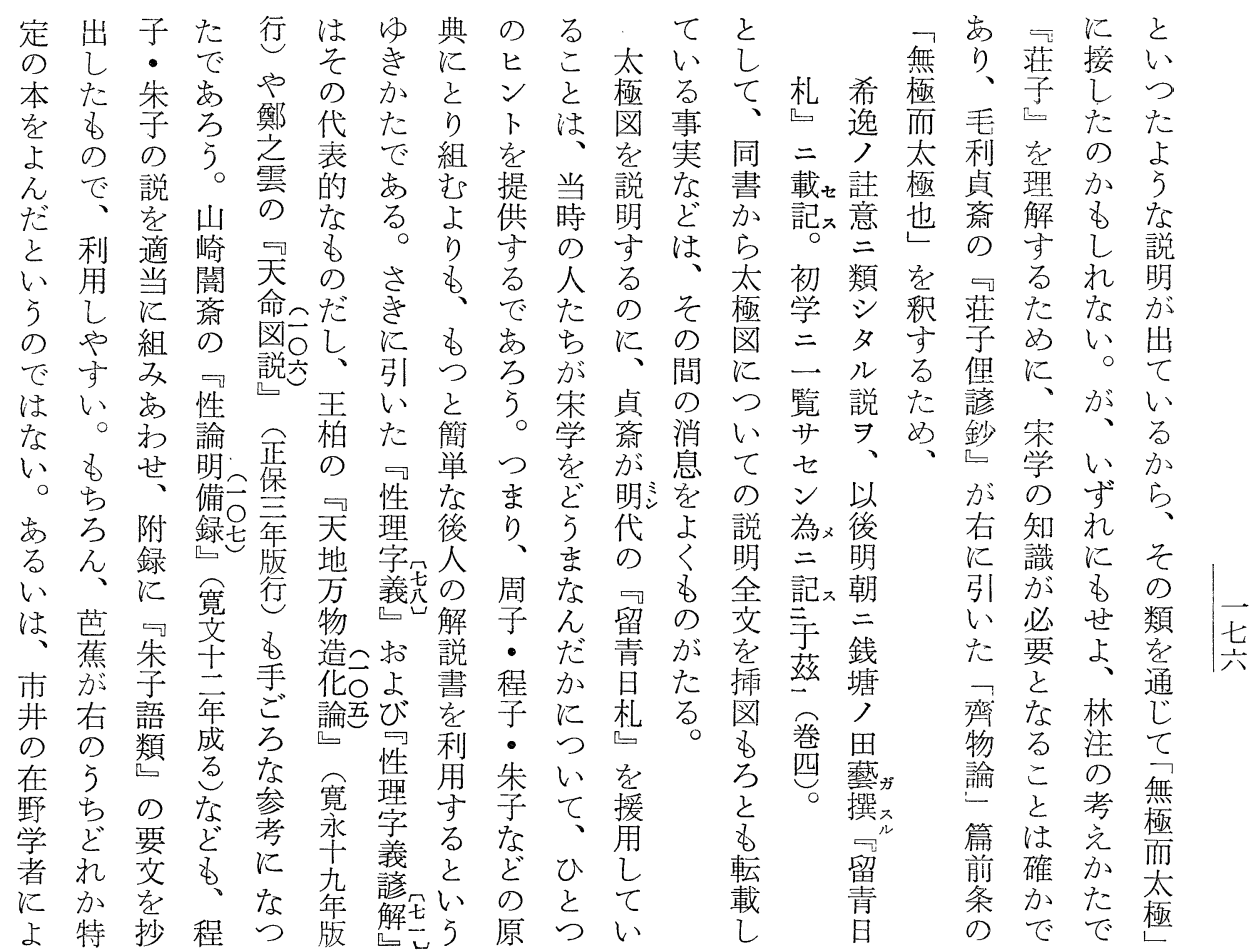




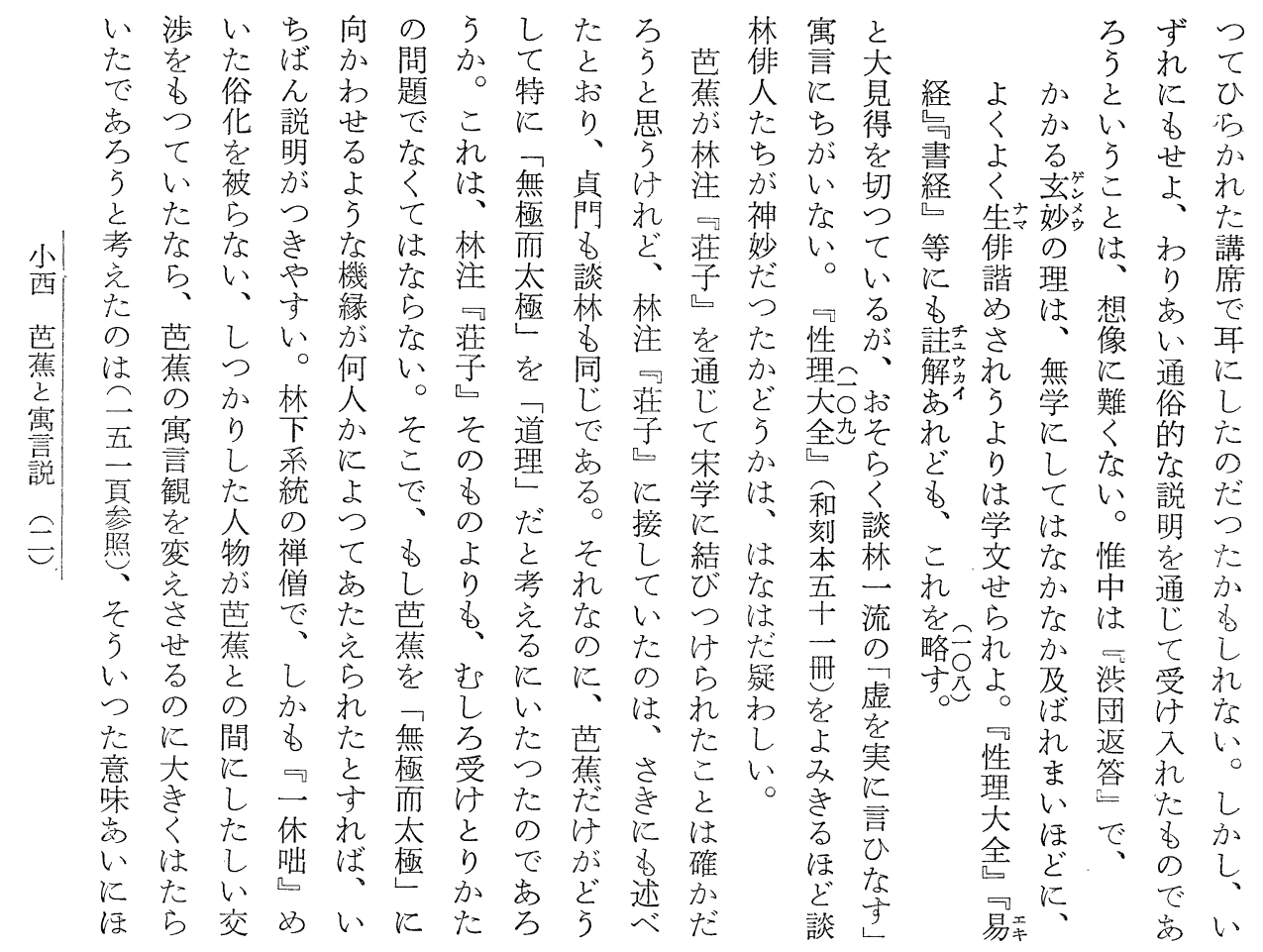

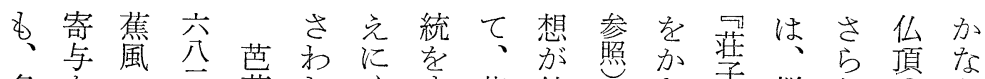

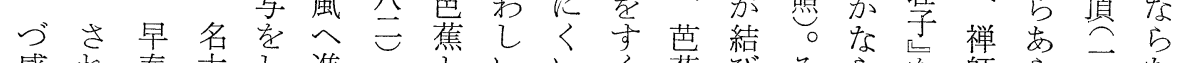

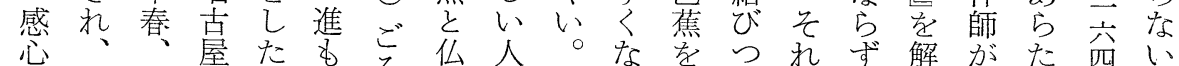

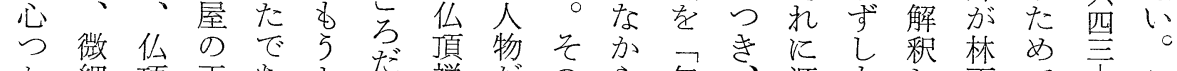

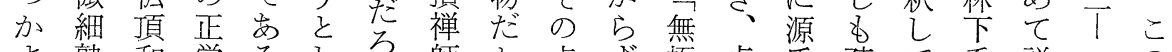

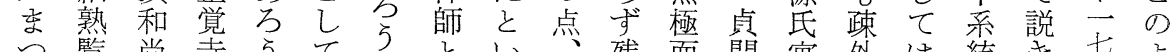
つ覽尚寺 5 て $\begin{gathered}5 \\ \text { と }\end{gathered}$

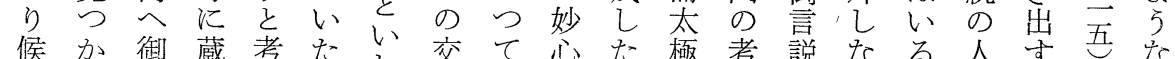
候か御蔵考た交て心た極考説なる人接な

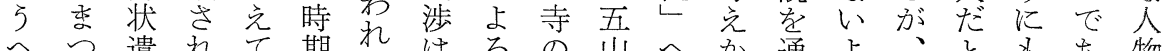

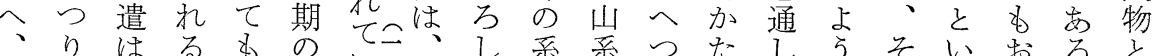

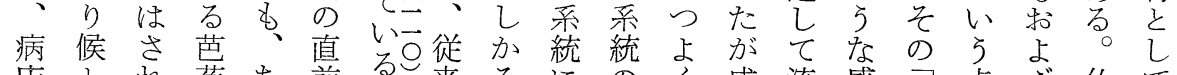

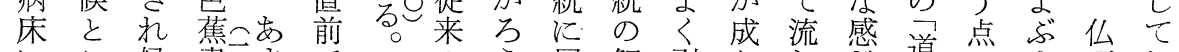

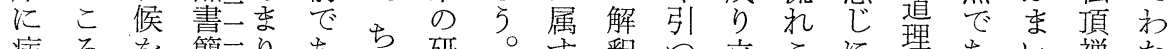

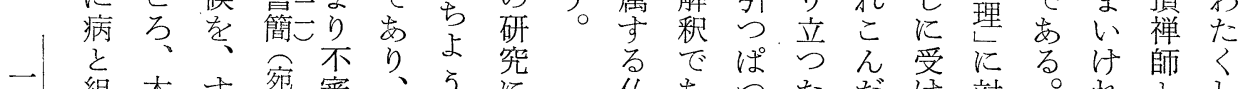

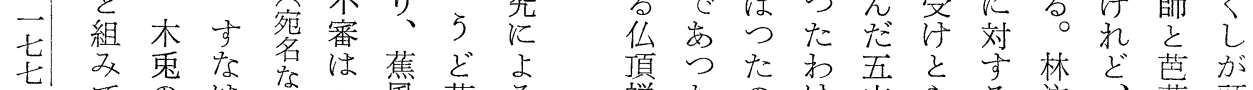

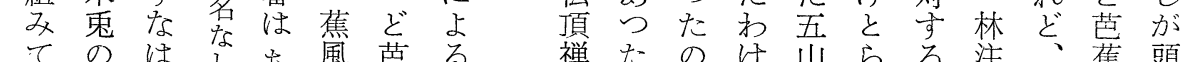
て のはし岕風芭る禅たのけ山らる注、蕉頭

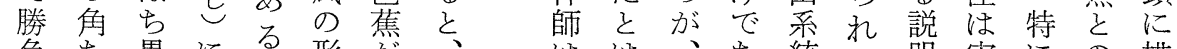

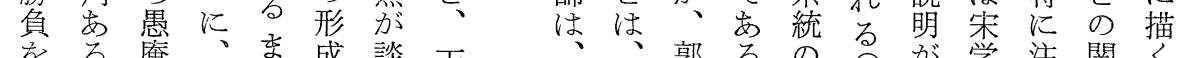

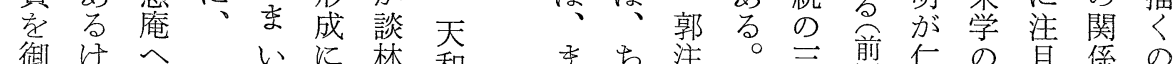

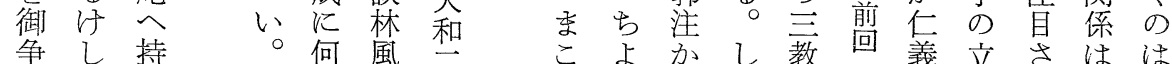

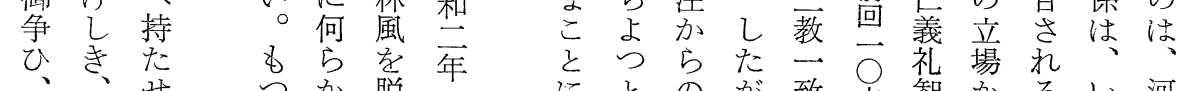

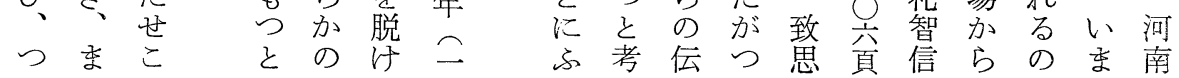




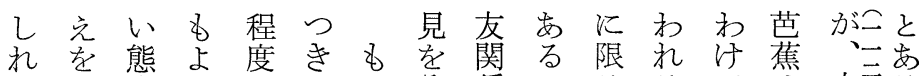

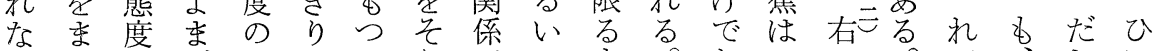

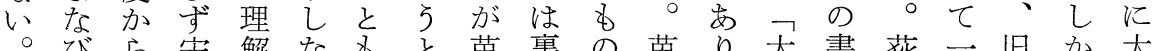
乙

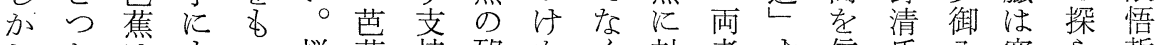
したは子蝉蕉持㱛をく対者す信氏入寒ら哲

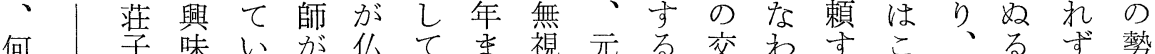

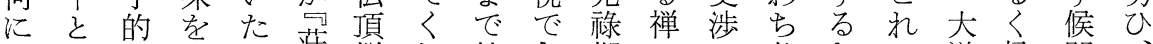

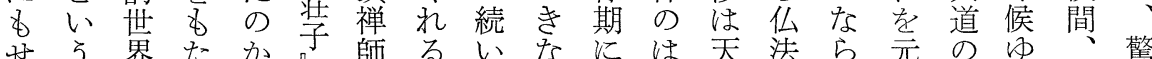

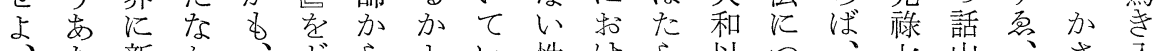

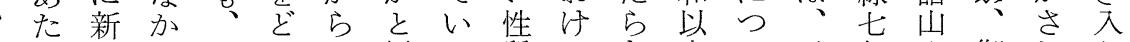
芭りしつやん具思た質るきき来い元年や御ね斿

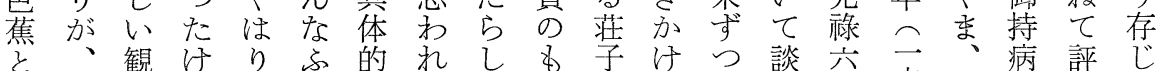

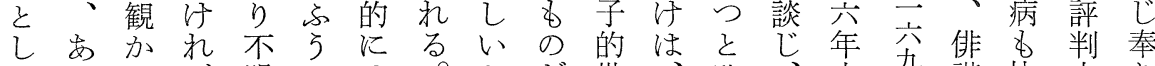
たるたど明には、をだ世枼、ひ杂諧快申り

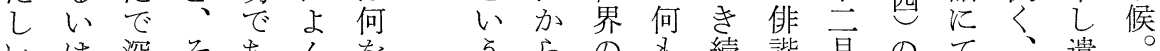
心交真恋の る

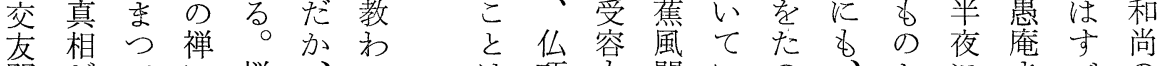

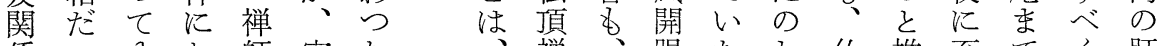
係つゆ㧍師宋た た禅、眼たし仏推至でく肝

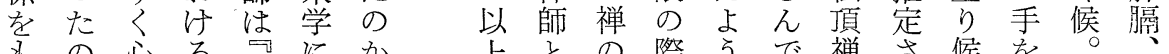

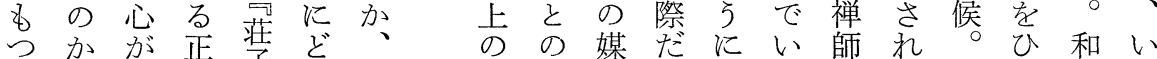

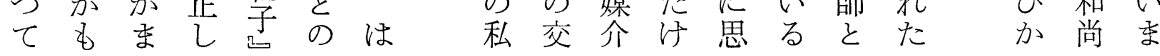

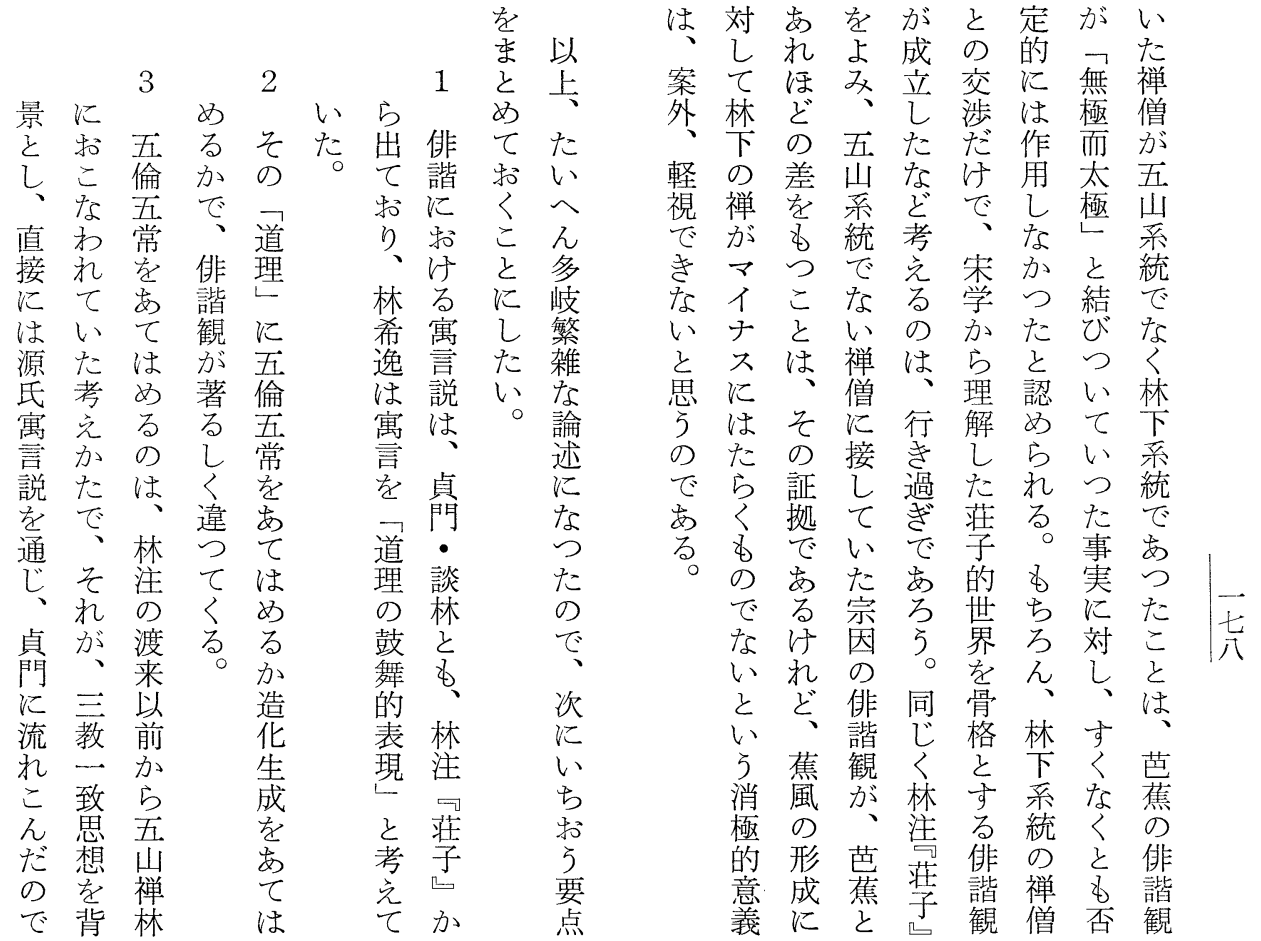




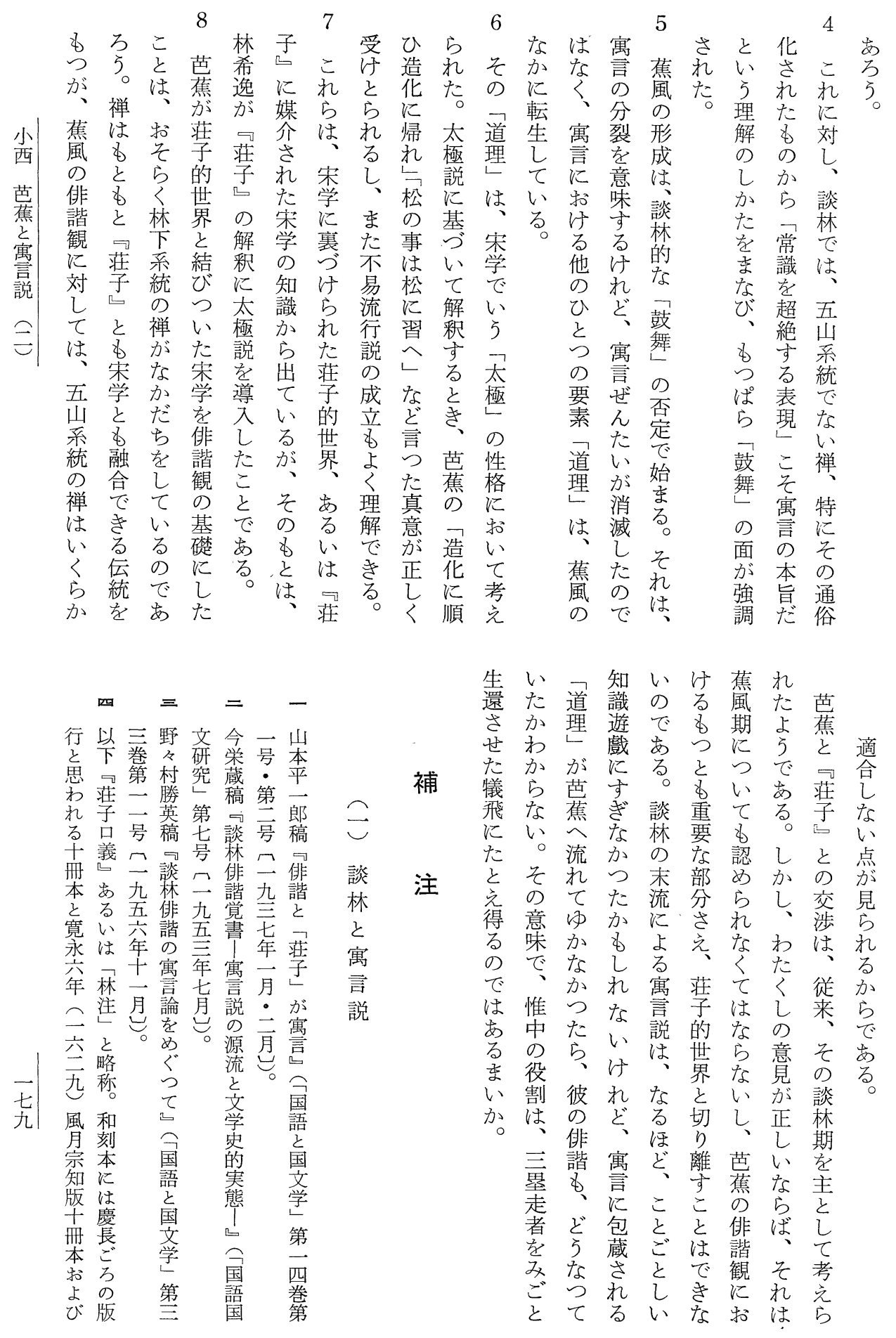




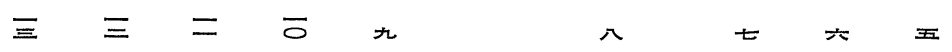

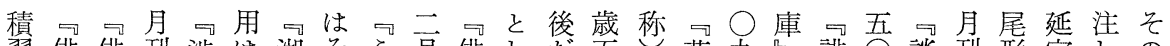
委俳俳刊渋は湖々 5 月俳乞だ五洼九誹

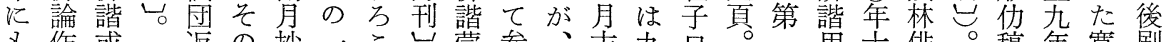

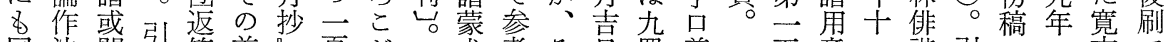

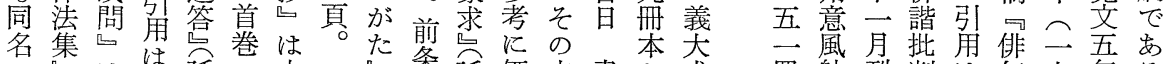

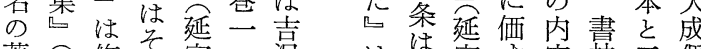

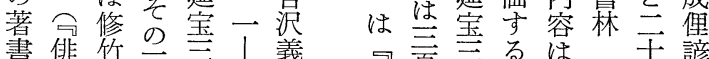

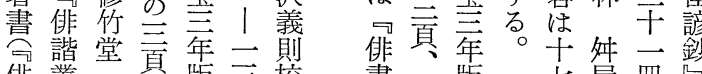

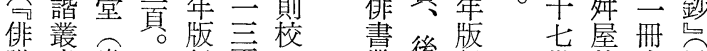

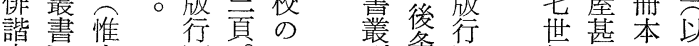

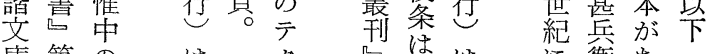

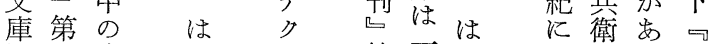
几四変可第 $\vec{\bigcirc}$ 可沶荘

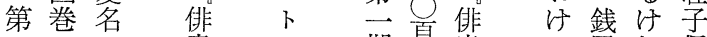

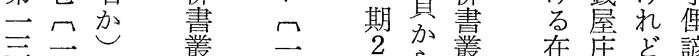
編九 の 分四著第辛杂公第

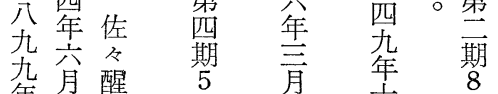

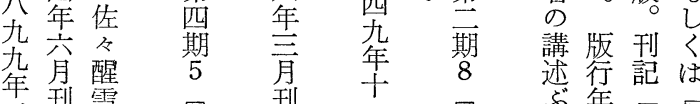

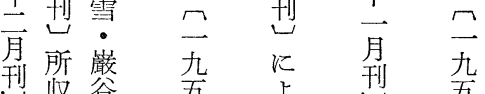

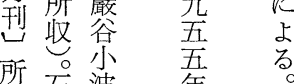

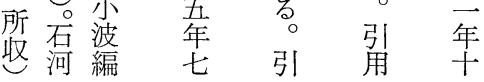

ぶ年 ᄀ

冊射刊判は句六年る

几岕行心そ俳分二方

一延岁はの論二二治

杂完引畕鬲版公年

年世大四旦行五乞 年版々学 1 本司風六 月篇 $\vec{O}$ 典子五 刊蛙妾吾鑑口庄九

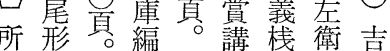
在庄ど謗乺形員編。講栈衛吉 学衛同慗㳊校俳夎船版権

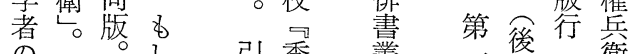

埇吟乘茫出書頭版 は俳恕巻荘十 爷䧻 第吕它奥

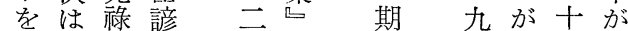
示芭十鈔 $\vec{\bigcirc}$ 五 9 五要冊学

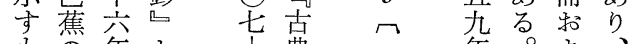
の殁未登略三典妾年。占加

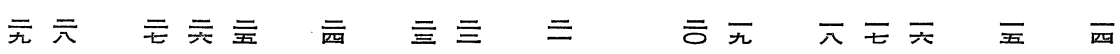

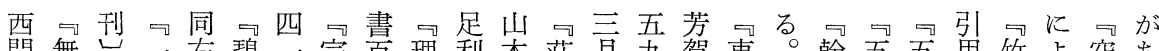

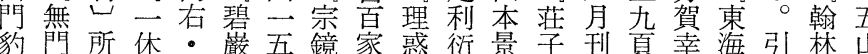

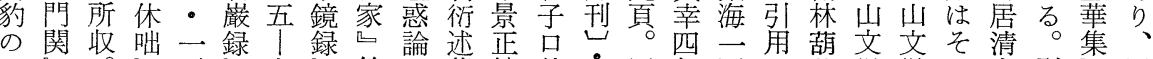

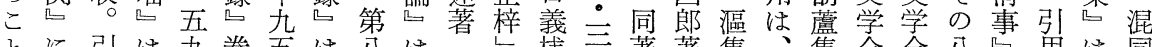

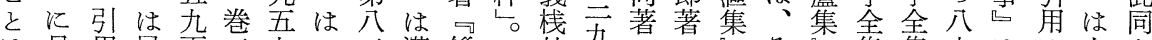

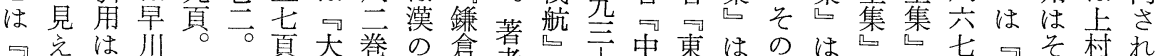

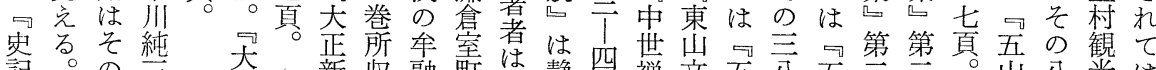

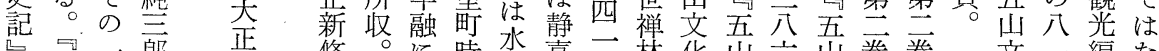
吴三郎、齗修。洔永嘉二林花山六山巻巻文一編な 列 大正編 第㜪頁近

突笑 藏

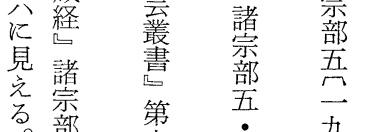

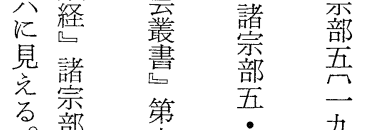

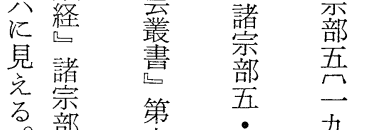

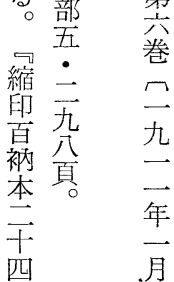

夲

蔵

経

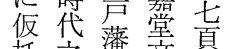

托檽番文

た教儒歷

論息蔵

畫口野十

光夳塘一

緒三塘冊

元年

吾

吾
学研学 問究全 物见集 よ 兄 び 立第 学西巻 儌年叹 関士收 研而角 究型岕 穵号气 杂吾四 吾主百 六年頁

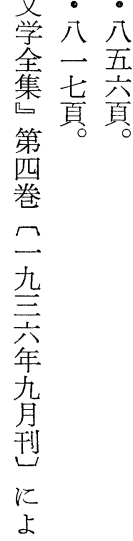

学五編

全了五な

集八山心

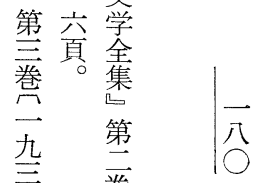




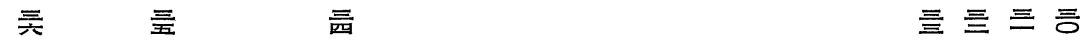

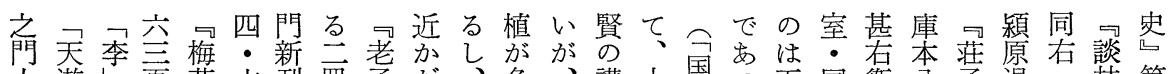

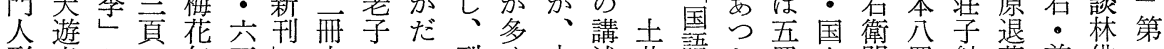

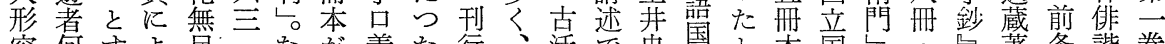
容何すよ尽三なが義た行、活で忠国と本国し。等条諧巻

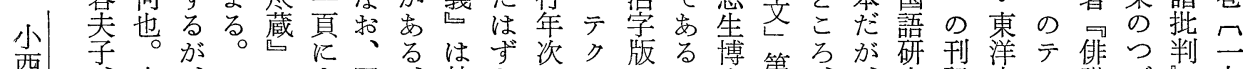

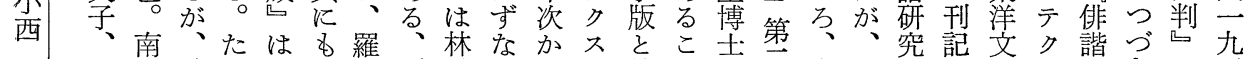
只華改だロ収山刊希のらト整と所无土や所を庫又串き。㮍吾

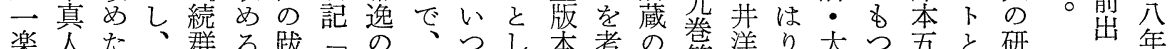

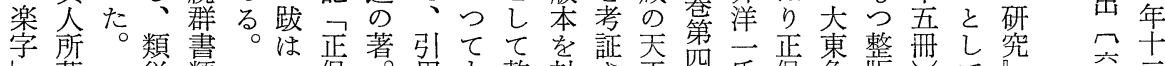

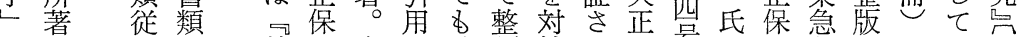

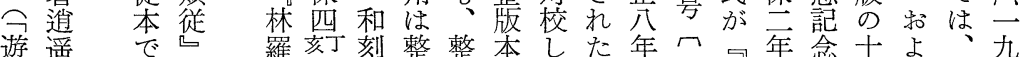

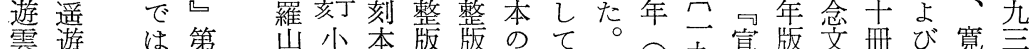

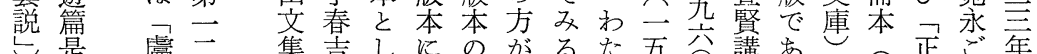

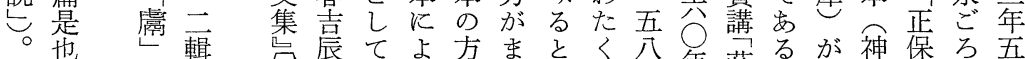

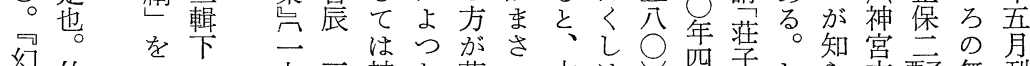

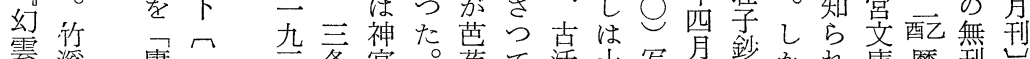

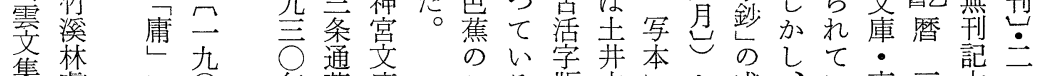

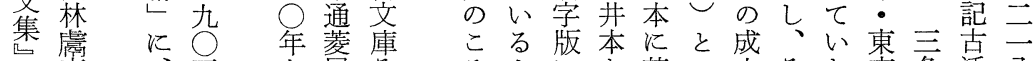

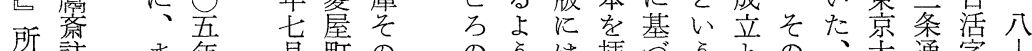

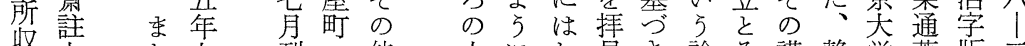

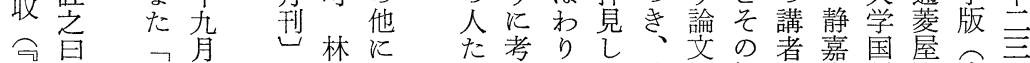

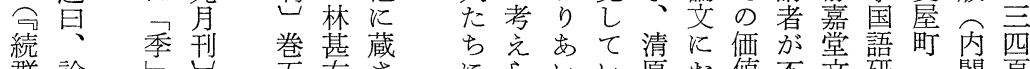

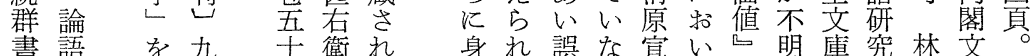

\section{吾至五吾罗 哛罗}

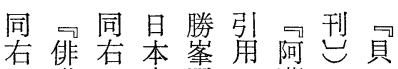
- 諧・古晋は蘭所物 四蒙二典風々陀所浽

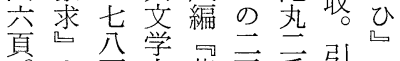
前頁菒芭踓番烈

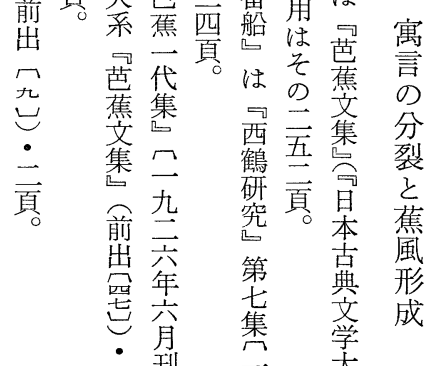
公

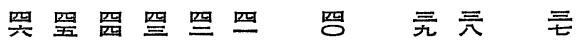

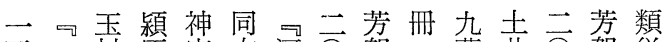

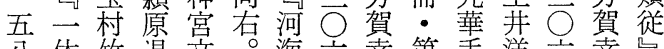

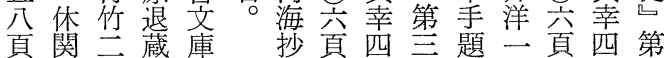
菄著著本

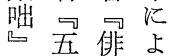
は山諧る。 近紊実江 世秫学研吉 蓄劣究初

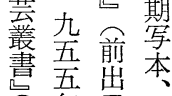
煎韋吾恶 茁冒刊 壱㟔三 第 三文 巻六物 所 ! 收三び 主買颁
抄頁嫏亚題公稿頁四第

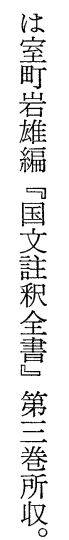

著。荘可著

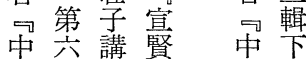
世冊義講 禅が心菻 のと足子 学の利鈔 問表学 打紙校の 上で遺成 び、跡 立 文九図々 学華書会 開筆館 9 関筆乺㖶 寸臓値 疍な゙し 研究军前 究外題本出 前㤎突镸 出交冊。 言る 第 
究

突

窐

䆓穾空

空突要吾要票吾

吾

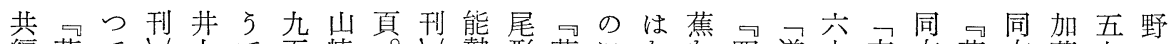
編芭て山上で吾崎。し勢形芭になな四道六方右芭右藤七々 蕉

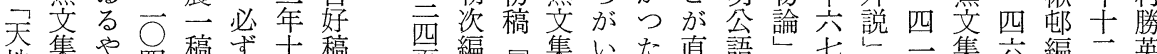

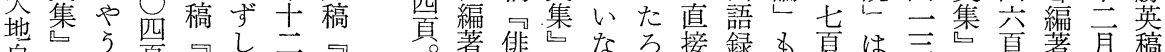

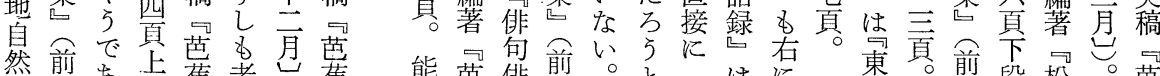
然出察段蕉老蕉 㷌出る段講䁬品を

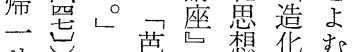
せ导芭蕉第想华妾

よ五 蕉第文解文法

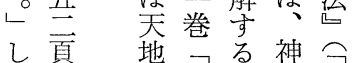

分頭自紀委神業解

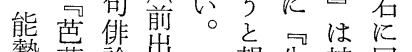
勢蕉論出想朱神同 朝講员甸 描座前艺 著篎出 芭第出五 蕉巻吾筫

ᄂ注 然行でな釈

自杉々篇す ぞ 衣な

然浦忍口い関賞

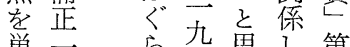

な郎多五惫た第

な郎名至尔語八

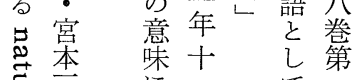

七

漠

然 創

ひ豆

意氏

使社坖导

俳俳 -

論論二

篇 七

九 $几$ 頁

元 九

分元

至

刊

三省

像子宮 じ

さ語文。

れ類庫九

る管蔵

沶四

そ立六

ら 巻 冊 而

こ 寛 刊

乙牒

類六晏

呩六童

略䒜辰

本を則

でよ吉

見导旦

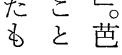

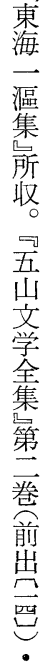

旦
本
学
志
院
紀
要
第
分
巻
第
葍
号

呬

트

士

t

を究 究

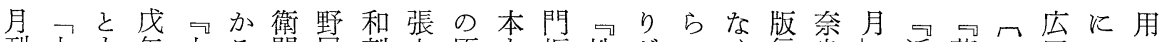
刊太も午太る門屋刻九原的板性どのく行良近芭一思はい

- 極近歳極 $\therefore$ 以䇥図 艺版月説 分天款解 父の旦旦 頁果ら立 にてで高熊 る解る通谷

解る通了

た 金の

の町頭

は、孫注

福 兵文

福
光
泀
著

衛つ

開 和

板 刻

눙

荘櫵引

装蕉引

点活 軼

九㲎記

吾帒誕

年它宝

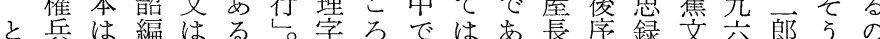
墨衛四揭が版義にこなろ兵に便集 $\bigcirc$ 稿しは 書板冊理げ、元諺はのらう衛子蒙年勾た、 乙行。学てこ名解な類な。乙詳前二芭用明 てょ刊類なちだっるのいしと亥説热月蕉法治 あ神記編いらら溹は る亮亏穴の か庫治原 な啠蔵年牒 僻の亥已 遠本八明 のは月の 地表吉洪 方紙旦武 に卉 流杰馬年

布曾場

乙庄通三

福示三

た島条分

こ伴元

と野町版

わ゙総吉行。

が 洞

後院 刊

刷通記

本六石

ら角方

心町

講

述山公

だ口月

市吉

で郎旦

あ 兵

つ衛荒

て 板川

陳々郎

北溪た湋

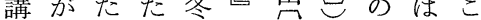

説、がけ十二䍡。造存の

が芭つま月干岂化在か

な蕉てるし冊・随した

さ肪㤎と任五順な、

れ当芭、亦、

て時蕉特る神頁

いの㤝そ。宮頭

た通直ら刊文注

万俗接 記庫

5 儒浣 元所

と書こ䈋蔵

いにの杂奆

こ按畫晝言

とた自こ椓言

推すな六蕰元

推すか杂䓪元

しばた宣甲

得、とご英戍

るそ拪光ろ堂秋

のい西

思。欧

悠齐

W 接

て

言 後

語叮

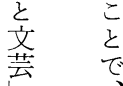

第 江

号期 


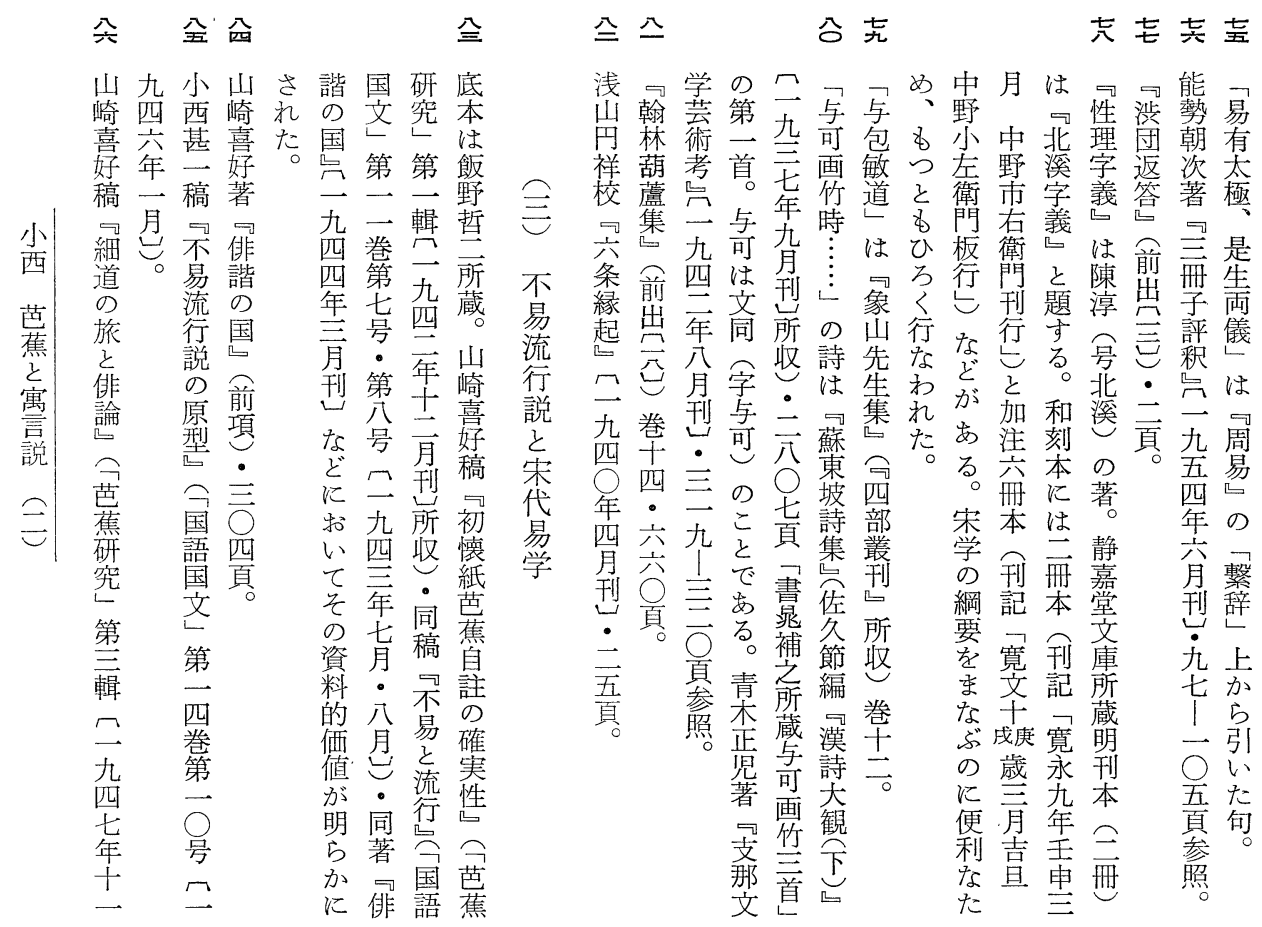

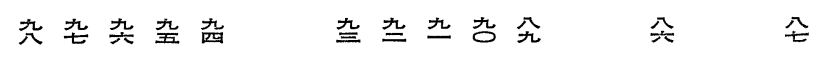

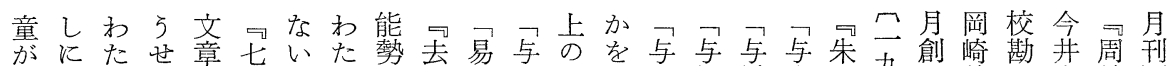

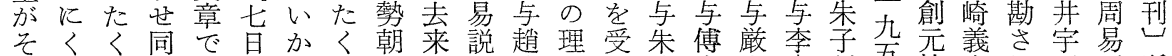

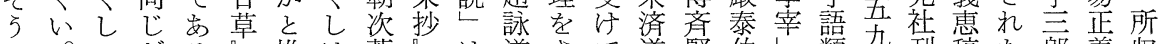

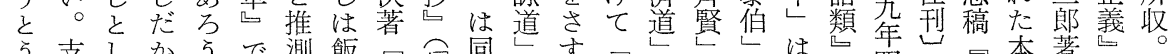

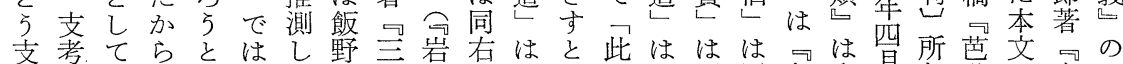

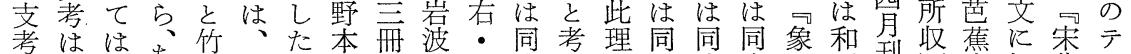

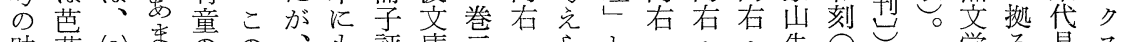

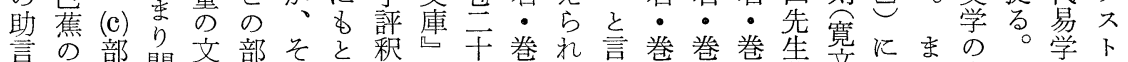

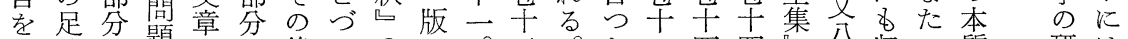

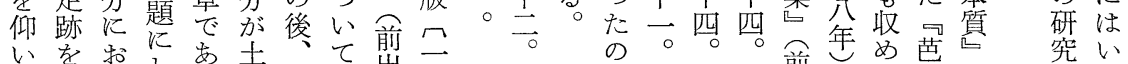

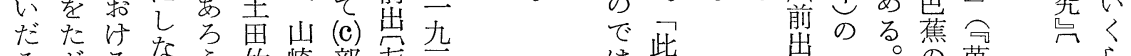

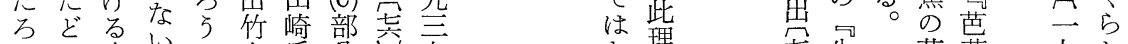

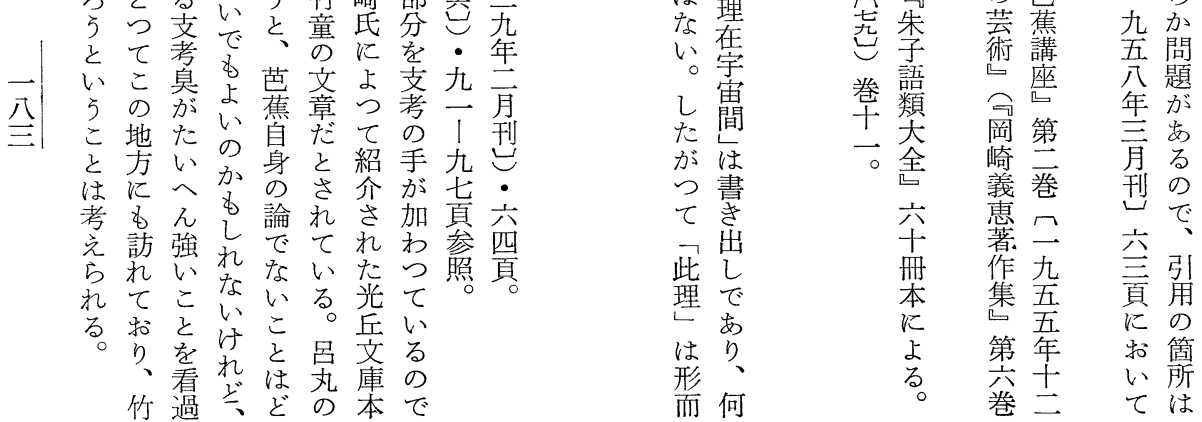




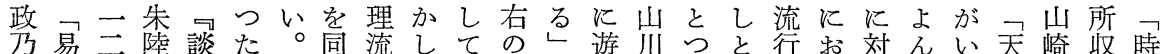

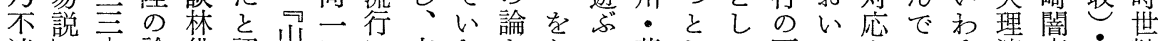

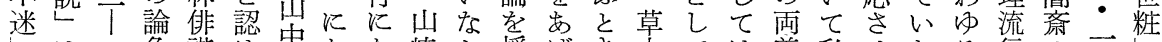

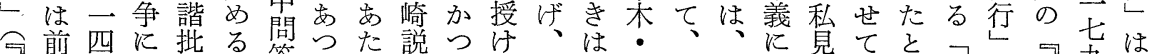

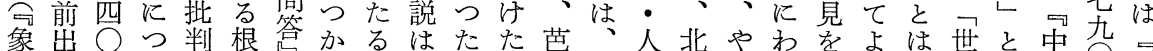

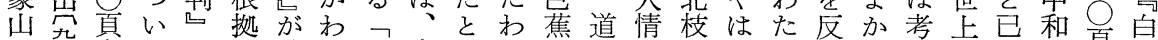

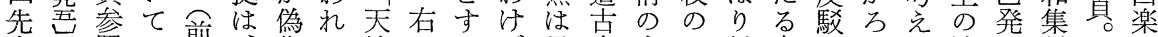
生。照は怔作た地のるだ呂今本、従宋さ5飞流の説

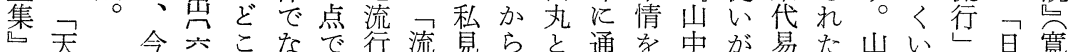

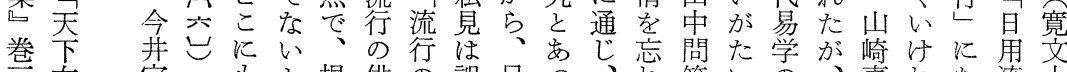

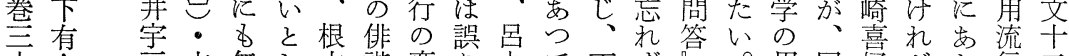

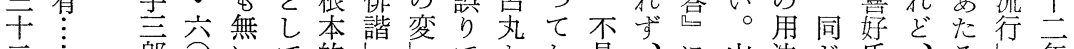

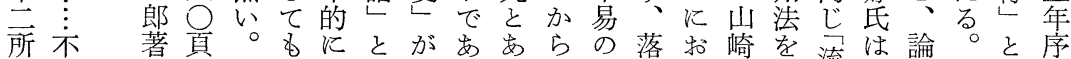

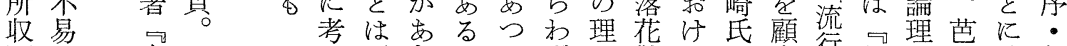

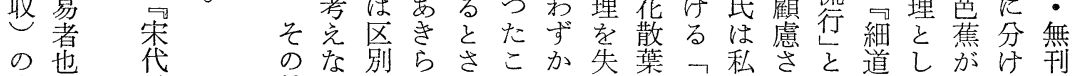

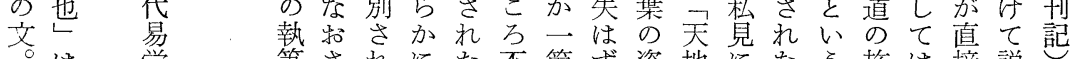
筆されにた不简ず姿地飞な5旅は接説起

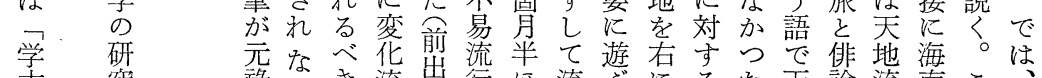

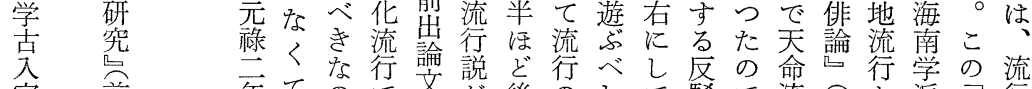

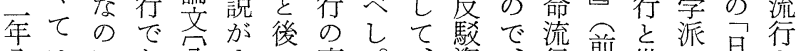

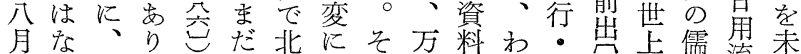

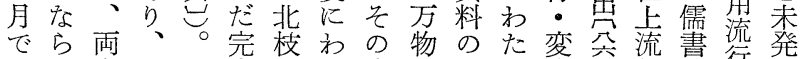

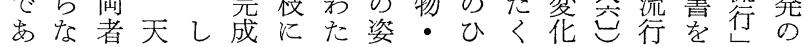

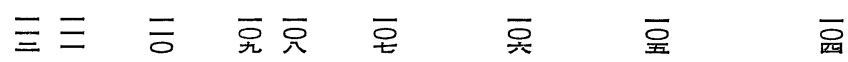

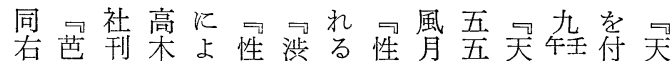

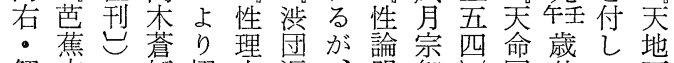

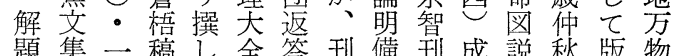

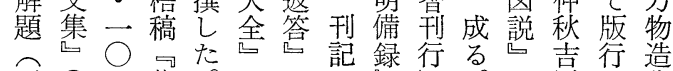

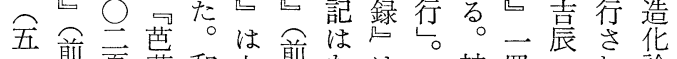

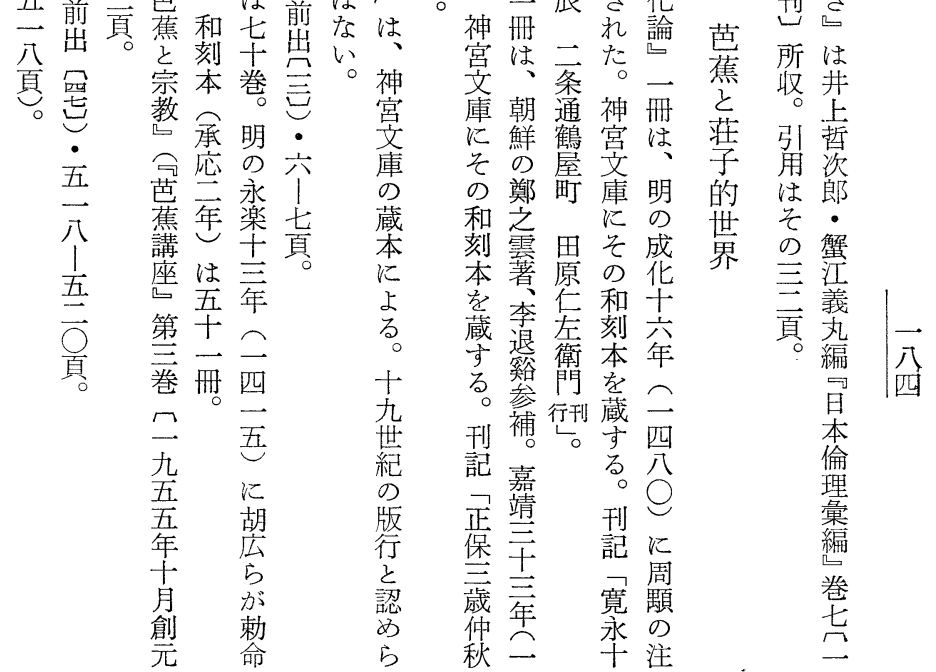

(n)

